\title{
The Manuscript Tradition of the Second Redaction of Nicole Oresme's Questions on Meteorology: Manuscript Descriptions and a Study of Their Relationships
}

The consultation of regional inventories and studies on Nicole Oresme, as well as the direct inspection of the manuscript sources, enabled me to identify nineteen manuscripts transmitting the second redaction of Nicole Oresme's Questions on Meteorology and one manuscript that contains a partial table of questions of this commentary. ${ }^{1}$

1) Basel, Universitätsbibliothek, lat. F I 11, ff. $4^{\mathrm{r}}-85^{\mathrm{r}}=B a$

2) Basel, Universitätsbibliothek, lat. F v 2, ff. $2^{r}-63^{v}=B a^{1}$

3) Berlin, Staatsbibliothek-Preußischer Kulturbesitz, lat. fol. 631, ff. 39 $9^{\text {r }}$ $114^{\mathrm{r}}=B e$

4) Erfurt, Universitäts- und Forschungsbibliothek, Dep. Erf., CA $2^{\circ} 334$,

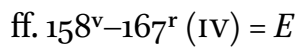

5) Kassel, Universitätsbibliothek — Landesbibliothek und Murhardsche Bibliothek, $2^{\circ}$ Phys. et hist. nat. 12 , ff. $1^{\mathrm{v}}-107^{\mathrm{r}}=K a$

6) Klagenfurt, Bischöfliche Bibliothek, XXXI b $5, \mathrm{ff}^{\mathrm{r}} \mathrm{1}^{\mathrm{r}}-124^{\mathrm{r}}=K l$

7) Kraków, Biblioteka Jagiellońska, cod. 749, ff. $59^{\mathrm{v}}-110^{\mathrm{v}}=K r$

8) Kraków, Biblioteka Jagiellońska, cod. 751 , ff. $3^{\mathrm{r}}-53^{\mathrm{r}}=K r_{1}$

9) Kraków, Biblioteka Jagiellońska, cod. 2095, ff. $245^{\mathrm{r}}-3 \mathrm{O} 7^{\mathrm{r}}=K r_{2}$

10) Kraków, Biblioteka Jagiellońska, cod. 2117 , ff. $195^{\mathrm{r}}-322^{\mathrm{r}}$ [pp. 389-643] $=K r_{3}$

11) Leipzig, Universitätsbibliothek, ms. $1387, \mathrm{ff} .181^{\mathrm{r}}-275^{\mathrm{r}}=L$

12) München, Bayerische Staatsbibliothek, Clm 4376, ff. $1^{\mathrm{r}}-64^{\mathrm{v}}=M$

13) München, Bayerische Staatsbibliothek, Clm 17226, ff. $1^{\mathrm{r}}-14 \mathrm{O}^{\mathrm{v}}(\mathrm{I} .2,4-6,1 \mathrm{O}$, 12-13, 17, II.1-7, III.7-10, IV.1-11) = $M^{1}$

14) Paris, Bibliothèque Nationale de France, lat. 15156 , ff. $226^{\mathrm{r}}-265^{\mathrm{v}}(\mathrm{I}-\mathrm{II} .1 \mathrm{O})=$ $P$

15) Poznań, Archivum Archidiecezjalne, Cms 53, ff. $1^{\mathrm{r}}-95^{\mathrm{v}}=P o$

16) St. Gallen, Stiftsbibliothek, Cod. Sang. 839, ff. $1^{\mathrm{r}}-177^{\mathrm{r}}=S g$

1 L. Thorndike, "Oresme and Fourteenth Century Commentaries on the Meteorologica", 145152; Birkenmajer, Études d' histoire des sciences en Pologne, 178-239; McCluskey, Nicole Oresme on Light, Color, and the Rainbow, 81-98; Weijers, Le travail intellectuel à la Faculté des arts de Paris, 6: 175; Lohr, Latin Aristotle Commentaries, i.2. Medieval Authors M-Z, 34-35; M. Markowski, “Aristotelica Poznaniensia", Acta mediaevalia 17 (2004), 281-293. 
17) Uppsala, Universitetsbibliotek, Ms. C 596 , ff. $2^{\mathrm{r}}-97^{\mathrm{r}}=U$

18) Wien, Österreichische Nationalbibliothek, Cod. 5453, ff. $49^{\mathrm{r}}-109^{\mathrm{v}}=W i$

19) Wrocław, Biblioteka Uniwersytecka, ms. IV Q 27, ff. $1^{r}-163^{r}=W r$

A partial list of questions of Oresme's commentary can be found in ms. Città del Vaticano, Biblioteca Apostolica Vaticana, Pal. lat. 1045, f. 118 ${ }^{\mathrm{v}}$.

\section{Manuscript Descriptions}

\section{$1 \quad$ Basel, Universitätsbibliothek, lat. F I 11, ff. $4^{r}-85^{r}$ (Ba)}

Paper; ff. II+209+I; mm 291× 204; 1369

Date and origin. The colophons of the texts transmitted in this manuscript inform us about the date and the origin of this codex, which was copied in 1369 at Prague University: "Expliciunt questiones super librum De anima per reverendum magistrum Byridanum, Parysius compilate, Prage reportate, etc." (f. $118^{\text {ra }}$ ); "Expliciunt questiones totius libri De celo per reverendum magistrum Albertum compilate et finite sub anno domini $1369^{\circ}$ (f. $209^{\text {ra }}$ ). The term reportate indicates that the text derives from a pronuntiatio, which was a common practice at Prague University. It consisted of a sort of collective dictation, which the Prague masters and bachelors used to teach the Aristotelian texts, based on the commentaries of famous masters from Paris and Oxford. ${ }^{2}$ The manuscript was bought by Peter of Ulma, physician and master, at Heidelberg; Peter sold it in 1559 to the University of Basel. ${ }^{3}$

Composition. Wooden binding partially covered with white leather. Clasps on the front cover. The strap and catch plate are missing. The binding is identical to that of manuscript F II 5 (see below). Two guard-leaves are numbered by a modern hand " 1 " and " 2 ". On the first leaf, a medieval hand wrote: "Librum hunc emebat universitas $\dagger$ de Olma et continentur primo questiones super libris Metheororum Aristotelis; secundo continet questiones Biridani super libris De anima; tertio questiones super libris De generatione et corruptione; quarto questiones Alberti super libris De celo et mundo. [alia manu] Ex libris bibliotece Basileiensis Academie, 1559". The guard-leaves are followed

2 On this practice see L. Moonan, "The Scientific Writings of Lawrence of Lindores (d. 1437)", Classica et Mediaevalia 39 (1988), 273-317, at 283-284 and J. Kejř, "Pronuntiatio", Studie o rukopisech 36 (2005-2006), 57-65.

3 For biographical information about Peter of Ulma, see E. Wickersheimer, Dictionnaire biographique des médecins en France au Moyen Âge, Geneva 1979 (Hautes études médiévales et modernes 34/1-2) (2 vols.), 2: 665a; D. Jacquart, Supplément à E. Wickersheimer, Dictionnaire biographique des médecins en France au Moyen Âge, Geneva 1979 (Hautes études médiévales et modernes, 35), 244. 
by 209 leaves grouped according to this formula: ${ }^{4}$ I $\left(3^{-19}\right)^{8+8}$; II $(19-30)^{7+7}$; III $\left(3^{1-46}\right)^{8+7}$; IV $(46-55)^{(8-1)+(7-4)}$; V $\left(5^{6-69}\right)^{7+7}$; VI $(70-83)^{7+7}$; VII $(84-85)^{1+1}$; VIII $(86-99)^{7+7} ;$ IX $(100-113)^{7+7} ; \mathrm{X}(114-121)^{4+4}$; XI $(122-129)^{4+4}$; XII $(130-143)^{7+7}$; XIII $\left(144^{-153}\right)^{5+5}$; XIV $\left(154^{-155}\right)^{1+1}$; XV (156-167 $)^{6+6}$; XVI $(168-179)^{6+6}$; XV (180191 ${ }^{6+6}$; XVII $(192-201)^{5+5}$; XVIII $(202-210)^{5+(5-1)}$. At the end of the volume, we find another guard-leaf, numbered 211. Catchwords: f. $17^{\mathrm{v}}$, f. $45^{\mathrm{v}}$, f. $55^{\mathrm{v}}$, f. $69^{\mathrm{v}}$, f. $99^{\mathrm{v}}$, f. $113^{\mathrm{v}}$. Signatures: f. $15^{6^{\mathrm{r}}}$ (pus); f. $168^{\mathrm{r}}(2) ; 18 \mathrm{o}^{\mathrm{r}}$ (3); f. $192^{\mathrm{r}}(4)$; f. $202^{\mathrm{r}}$ (5).

The volume consists of two main parts: ff. 1-119 and ff. 12O-211, which present two different medieval foliations. A modern hand has numbered the leaves from the beginning to the end of the volume. ${ }^{5}$ As a consequence, the medieval and the modern foliations are shifted by 119 units in the second part of the volume. In the first part, the gap between the two foliations is three units wide, since the medieval foliation starts with Oresme's Questions on Meteoro$\operatorname{logy}$ (numbered 4 according to the modern foliation), while the modern one also includes the guard-leaves (numbered 1 and 2) and the table of contents (numbered 3).

Content. This manuscript contains a collection of commentaries on natural philosophy by Parisian masters of the fourteenth century: Nicole Oresme's

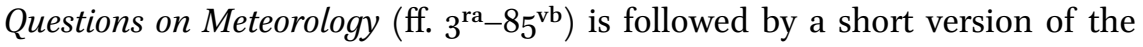
redactio $A$ of Buridan's Questions on De anima (ff. $\left.86^{\text {ra }}-118^{\text {ra }}\right),{ }^{6}$ by the redactio $B$ of Buridan's Questions on De generatione et corruptione ( $\left.\mathrm{ff.} 120^{\mathrm{ra}}-155^{\mathrm{vb}}\right)^{7}$ and

4 To represent the structure of the fascicules, I have adopted the method used in the catalogue of medieval Latin manuscripts of the Jagiellonian Library in Krakow: Catalogus codicum manuscriptorum medii aevi latinorum qui in Bibliotheca Jagellonica Cracoviae Asservantur, Wrocław 1980-. The Roman numeral before the brackets indicates the order of the fascicule; the two Arabic numbers between brackets indicate the first and the last leaf of the fascicule according to the foliation adopted; the formula in the exponent expresses the number of leaves that compose the fascicule. The numbers before and after the + sign indicate, respectively, how many leaves there are before and after the thread. A quaternion is thus expressed by the formula $4+4$; a quinion, by the formula $5^{+} 5$; a senion, by the formula $6+6$, and so on. The addition or subtraction of some leaves is expressed by operands + and -, followed by the quantity of the added or missing leaves. For example, the formula $5^{+}\left(5^{-1}\right)$ represents a fascicule composed by two quinions, the second of which has a missing leaf. I have preferred this codicological formula to the more widely used German one because it allows us to express clearly which part of the fascicule is concerned by the addition or the subtraction of leaves.

5 In this description, I refer to the modern numbering.

6 B. Michael, Johannes Buridan. Studien zu seinem Leben, seinen Werken und zur Rezeption seiner Theorien im Europa des späten Mittelalters, Berlin 1985 (2 vols.), 2: 684, nr. 20.21; Lohr, Latin Aristotle Commentaries, i.2. Medieval Authors M-Z, 257-257, nr. 24.

7 Michael, Johannes Buridan, 2: 635-641. 
by Albert of Saxony's Questions on De celo (ff. $15^{6^{\mathrm{ra}}-209^{\mathrm{ra}}}$. This codex also contains some texts on logic: a fragment from the Libellus de terminis naturalibus, a dictionary of basic terminology used by the Oxford Calculators (ff. $\left.118^{\mathrm{r}-\mathrm{v}}\right)^{8}$ and a fragment of Albert of Saxony's Expositio on Aristotle's Posterior Analytics (ff. $209^{\mathrm{rb}}-210^{\mathrm{va}}$ ).

The Questions on Meteorology. The colophon attributes the commentary to Nicole Oresme: "Expliciunt questiones libri Meteororum vel Metheororum seu Methaurorum reverendi magistri Nycolai Orem, viri multum experti, ut in istis dictis suis poterit apparere" (f. $85^{\mathrm{vb}}$ ). The text is copied in two columns of about fifty lines each. The content of ff. $5^{2^{\mathrm{v}}}$ and $53^{\mathrm{r}}$ has been crossed out with a big X that covers the entire page. On f. $53^{\text {rb }}$, the copyist wrote: "verte folium et invenies ultra quantum ad secundum, etc. Et hic nichil deficit, ut videbis, sed indirecte et incorrecte nimis scriptum erat, ideoque absasum [sic] est et secundario scriptum est, et hoc magis correcte et bene. Deo gratias". On f. $75^{\mathrm{vb}}$, 1. 6 , the hand changes, as happens on $\mathrm{f} .83^{\text {ra }}$. The incipits are written in textualis but the decoration has not been completed, since the white space set aside for the initials is at times left blank (for example at f. $39^{\mathrm{vb}}$ ). Moreover, the headings of the questions only reach question I.6, on $\mathrm{f} .9^{\mathrm{rb}}$, after which the space set aside for them remains empty. The pilcrows stop at $\mathrm{f} .10^{\mathrm{rb}}$. At the beginning of the text, a big Q extends over the space of eight lines. Pointing hands (f. $5^{\mathrm{va}}$ ); some rare marginal notes related to the structure of the text. Some nota bene in a medieval hand (for example at f. $49^{\text {rb: }}$ "nota bene quod templa et monasteria percutiantur a fulmine sepius quam alie structure"). On f. 3 , we find a table of contents.

Incipit and explicit of the books

I, ff. $4^{\text {ra }}-26^{\text {va }}$ : Queritur circa librum Metheororum primo ista questio: utrum possibile sit de impressionibus metheorologicis habere scientiam et opinionem. Et arguitur quod non, quia de eis non contingit habere scientiam nec opinionem; igitur questio falsa ...X... Ad quartam: 'si galaxia esset de natura celi', etiam concedo. Sed tamen Aristoteles determinavit de ea in isto libro propter hoc quia plures antiquorum tradiderunt galaxiam esse de natura elementari. Et sic est finis questionum huius libri primi. Explicit primus liber Metheororum.

II, ff. $26^{\mathrm{vb}}-39^{\mathrm{vb}}$ : $\langle\mathrm{C}\rangle$ irca secundum librum Metheororum queritur utrum locus generationis pluvie sit media regio aeris. Arguitur quod non: nullum elementum debet generari extra locum sibi naturalem ...X... Ad rationes in oppositum patet ex secundo articulo.

8 Inc.: "Natura est principium motus et quietis eius in quo est. Istam diffinitionem ponit Aris- 
III, ff. $39^{\mathrm{vb}}-78^{\mathrm{rb}}:\langle\mathrm{Q}\rangle$ ueritur consequenter circa tertium librum Methaurorum utrum ventus sit exalatio calida et sicca. Et arguitur quod non sit calida, quia sic sequeretur quod in temporibus ventosis aer deberet esse calidus ...X... Ad ultimam dico quod non in vanum laborant, ex quo aliam artem ignorant. Et sic patent questiones tertii Metheororum.

IV, ff. $78^{\mathrm{rb}}-85^{\mathrm{vb}}$ : Circa quartum librum Metheororum queritur primo ista questio: utrum sunt quatuor qualitates prime, scilicet caliditas, humiditas, frigiditas et siccitas. Et arguitur primo quod non, quia quod per superhabundantiam dicitur, uni soli convenit ...X... Ad sextam dico quod in salamandra non dominatur ignis in quantitate nec etiam nutritur ab igne; sed tale animal non est ustibile ab igne; et ideo, quia non uritur ab igne, dicimus quod tale animal habitet in igne. Et sic patet ultima questio istius. Expliciunt questiones Metheororum magistri Nycolai Orem. [85 ${ }^{\mathrm{vb}}$ ] Expliciunt questiones $\mathrm{Me}$ teororum vel Metheororum seu Methaurorum reverendi magistri Nycolai Orem, viri multum experti, ut in istis dictis suis poterit apparere.

\section{Bibliography}

Catalogues: B.M. von Scarpatetti, R. Gamper, and M. Stähli, Katalog der datierten Handschriften in der Schweiz in lateinischer Schrift vom Anfang des Mittelalters bis 1550, 1: Die Handschriften der Bibliotheken von Aarau, Appenzell und Basel, Dietikon/Zurich 1977, 171; Lohr, Aristotelica Helvetica, 34-36; Ch. Lohr, Latin Aristotle Commentaries, I.2. Medieval Authors M-Z: 40, 256, 258; 2: 34 [here the manuscript is incorrectly dated to the $15^{\text {th }}$ century].

toteles in secundo Physicorum et etiam Commentator". This text is ascribed to Iohannes Garisdale by Ch. Lohr (Aristotelica Helvetica, Fribourg (Switzerland) 1994, 34-36), but this attribution is still a matter of debate, as texts with similar incipits have been ascribed also to William Heytesbury, Iohannes Gardisdale and Thomas Netter. A.R. Verboon studied and edited a version of this text ascribed to a certain "master Albertus". See A.R. Verboon, Lines of Thought. Diagrammatic Representation and the Scientific Texts of the Arts Faculty, 12001500, unpublished Ph.D. dissertation, Leiden University 2010, Appendix A, 239-250, available online at https://openaccess.leidenuniv.nl/handle/1887/16o29; revised edition: A.R. Verboon and E.P. Bos, Master Albert:Termini naturales, in C. Angotti, M. Calma, and M. Teeuwen (eds.), Portraits de Maîtres offerts à Olga Weijers, Turnhout 2012 (Textes et Etudes du Moyen Âge, 65), 335-36o. This attribution can be found in the two manuscripts used by Verboon for her edition: Paris, Bibliothèque Nationale de France. lat. 566 , ff. $49^{\mathrm{r}}-5^{8^{\mathrm{r}}}$ and Assisi, Biblioteca del Sacro Convento di S. Francesco, fondo antico, ms. 69o, ff. $314^{\mathrm{r}}-319^{\mathrm{r}}$. Our manuscript was unknown to A.R. Verboon. Lohr (Aristotelica Helvetica, 110) mentions another text with a similar incipit kept at Basel University library: F VI 58 , ff. $301^{\mathrm{r}}-306^{\mathrm{v}}$. I wish to express my gratitude to Miroslav Hanke (Czech Academy of Sciences) for information on this text. 
Literature: M. Burckardt, "Aus dem Umkreis der ersten Basler Universitätsbibliothek", Basler Zeitschrift für Geschichte und Alterumskunde, 58/59 (1959), 155-191, nr. 164; B. Michael, Johannes Buridan, 2: 636, 686 [here the manuscript is incorrectly dated to the $15^{\text {th }}$ century]; McCluskey, Nicole Oresme on Light, Color, and the Rainbow, 83-84; M. Streijger, P.J.J.M. Bakker, and J.M.M.H. Thijssen (eds.), John Buridan, Quaestiones super libros De generatione et corruptione Aristotelis, Leiden/Boston 2010 (Medieval and Early Modern Philosophy and Science, 14) [here the manuscript is incorrectly dated to the $15^{\text {th }}$ century].

2

Basel, Universitätsbibliothek, lat. F V $2, f f \cdot{ }^{r a}-63^{v a}\left(\mathrm{Ba}^{1}\right)$

Paper; mm 288× 213; 140 ff.; 1369

Date and origin. Just like the manuscript F I 11, this codex comes from the University of Prague. The first part, which contains Nicole Oresme's Questions on Meteorology, dates to 1369 , as is evident from the colophon at f. $63^{\text {rb: "Anno }}$ domini millesimo $\mathrm{CCC}^{\circ}$ sexagesimo nono finite sunt questiones Metheororum". But the similarities between this codex and manuscript F I 11 do not stop there. Like the latter, this manuscript was also bought by Peter of Ulma, who resold it to the University of Basel. On the first inside cover and on the first leaf we find a possession mark: "Ex libris Bibliothece Academie Basileiensis, 1559"; and at f. $1^{\text {r: }}$ "Hunc librum emebat universitas de libris magistri Petri de Olma". On f. $63^{\text {ra }}$, between Oresme's Questions on Meteorology and the table of contents, we find an epigram that is considered the oldest document in Old Prussian: "Kayle rechyse / Thoneaw labonache thewelyse /eg koyte poyte nykoyte pennega doyte". 9

Composition. Wooden binding partially covered with white leather. Two clasps on the front cover. The strap and the catch-plate are missing. The binding is identical to that of manuscript F I II. A paper guard-leaf, numbered 1, contains the following statement: "Hunc librum emebat universitas de libris magistri Petri de Olma et continetur in eo vide signa. Item primo continentur in eo questiones super libris Metheororum magistri N. Orem; secundo questiones Biridani super libris De generatione et corruptione; tertio questiones super libris De anima; quarto questiones super libris De celo et mundo; quinto quedam puncta circa computum manualem". The guard-leaf is followed by 139 paper

9 See A. Bammesberger, Anmerkungen zum Baseler Epigramm, in Id., Baltistik: Aufgaben und Methoden. Akten der Tagung vom 10. bis 11. November 1995 in Eichstätt, Heidelberg 1968, 121126; D. Petit, Untersuchungen zu den baltischen Sprachen, Leiden/Boston 2010 (Brill's Studies in Indo-European Languages and Linguistics, 4), 22. 
leaves grouped mainly in senions, according to the following formula: I (2$13)^{6+6}$; II $(14-25)^{6+6}$; III $(26-37)^{6+6}$; IV $(38-49)^{6+6}$; V $\left(5^{\mathrm{O}-63}\right)^{7+7}$; VI $(64-74)^{6+6} ; 10$ VII $\left(75^{-86}\right)^{6+6}$; VIII $(87-98)^{6+6}$; IX $(99-111)^{6+6} ; \mathrm{X}(112-121)^{5+5}$; XI $(122-135)^{7+7}$; XII $(136-140)^{(4-1)+(4-2)}$.

The manuscript consists of two main parts: the first one covers fascicules I-V (ff. 2-63); the second one, senions VI-XII (ff. 64-140). Fascicules I-V contain signatures that prove that the volume was arranged differently during the Middle Ages. These senions are numbered: "nonus", "decimus", "undecimus", "duodecimus", "tredecimus". Another arrangement is suggested by signatures in fascicules IX (2us), X (3us) and in fascicules XI (1us) and XII (2us). Fascicules IX and $\mathrm{x}$ are in fact the second and the third fascicule of the Questions on De anima, while fascicules XI and XII are the first and the second quire of the Questions on De celo. Other signatures in the lower margins of senions IV and $\mathrm{v}$, between the columns, reflect the current arrangement of the volume: "quartus" and "quintus".

The original division of the volume into two parts is confirmed by the medieval foliations: the first one covers fascicules $I-V$, numbered $2-63$ by a medieval hand; the second one covers fascicules VI-XII, numbered $1-78$ by a medieval hand too. A third foliation, written by a modern hand, stretches across the whole volume. ${ }^{11}$ An error in the modern foliation occurs between $\mathrm{f} .72$ and f. 73 ( 9 and 11, according to the second medieval foliation): f. 72 is followed by another 72 , which was therefore numbered $72^{\circ}$. In the first part of the volume, the medieval and the modern foliation correspond to each other. In the second part of the volume, they are shifted by 63 units until $\mathrm{f} .72$ according to the modern foliation, and by 62 units from the subsequent folio, numbered $72^{\circ}$ according to the modern foliation.

Content. The content of this codex is very similar to that of ms. F I 11. As in the latter manuscript, Oresme's Questions on Meteorology (ff. $2^{\text {ra }}-63^{\mathrm{va}}$ ) is followed by the redactio B of Buridan's Questions on De generatione et corruptione (ff. $64^{\mathrm{ra}-86^{\mathrm{rb}}}$ ), by a short version of the redactio A of Buridan's Questions on De anima (ff. $87^{\text {ra }}-120^{\text {ra }}$ ) and by Albert of Saxony's Questions on De celo, this time in a shortened form (ff. $\left.122^{\text {ra }}-139^{\text {rb }}\right) . .^{12}$ The codex also contains an anonymous

\footnotetext{
10 The leaf between $\mathrm{f} .72$ and $\mathrm{f} .73$ is numbered $72^{\circ}$.

11 In this description I always refer to the modern foliation.

12 Inc.: "Circa librum De celo et mundo Aristotelis queritur primo questio talis: utrum cuilibet corpori simplici naturaliter insit tantum unum motus simplex. Et arguitur quod non"; q. I.2: "Secundo queritur utrum in mundo sint quinque corpora distincta secundum speciem, scilicet quatuor elementa et celum, scilicet quinta essentia"; q. I.3: "Tertio, utrum preter elementa et celum sit ponendum sextum corpus simplex"; q. I.4, "Quarto,
} 
question on logic $\left(120^{\mathrm{va}}-121^{\mathrm{ra}}\right)^{13}$ and some Puncta on the Computum manuale (ff. $\left.139^{\text {rb }}-140^{\text {va }}\right) .14$

The Questions on Meteorology. The colophon and the table of contents ascribe the commentary to Nicole Oresme: "Et sic est finis questionum Oren super Metheororum", f. 63 ${ }^{\text {ra; }}$ "et tantum de questionibus Metheororum magistri N. Orem", f. $63^{\text {va }}$. The text is copied by different hands using different inks (some examples are: the change of hand and ink on f. $9^{\mathrm{vb}}, \mathrm{l}$. 14; the change of ink on $\mathrm{f}$. ${ }^{\mathrm{v}} \mathrm{vb}$; hands repeatedly changing on $\mathrm{ff} .22^{\mathrm{v}}-23^{\mathrm{r}}$; abrupt change of hand on $f .3 \mathrm{O}^{\mathrm{v}}$ ) and laid out in two columns. Brown-inked pilcrows are highlighted with a vertical red stroke. Some marginal notes refer to the structure of the text. Corrections in black ink (particularly recognisable between $\mathrm{ff} .2^{\mathrm{ra}}-9^{\mathrm{vb}}$ in contrast with the pale brown ink of the main text). The first words of the questions between $\mathrm{ff} .2^{\mathrm{ra}}-1 \mathrm{O}^{\mathrm{va}}$ are in textualis. From f. $11^{\mathrm{va}}$ onwards, the questions are separated by a simple blank space. On f. $35^{\mathrm{v}}$ and f. $43^{\mathrm{r}}$, we find drawings related to the text. The commentary is followed by a table of contents (ff. $\left.63^{\mathrm{r}}-63^{\mathrm{v}}\right)$ written by a different hand from those that copied the text.

Incipit and explicit of the books

I, ff. $2^{\text {ra }}-17^{\text {ra }}$ : $\langle$ C $\rangle$ irca primum librum Metheororum utrum possibile sit de impressionibus metheoroloycis haberi scientia simul et opinio. Et arguitur quod non, quia de eis non contingit habere scientiam nec opinionem; igitur questio falsa ...X... Ad quartam: 'si esset $\left[17^{\text {ra }}\right]$ de natura celi', etc., dico: tamen Aristoteles determinavit de ea propter hoc quia plures antiquorum crediderunt galaxiam esse de natura elementari. Et sic est primi libri finis.

II, ff. $17^{\mathrm{ra}}-25^{\mathrm{vb}}$ : Utrum locus generationis pluvie sit media regio aeris. Arguitur quod non: nullum elementum debet generari extra locum sibi naturalem ...X... Ad rationes in oppositum patet ex secundo articulo.

III, ff. $25^{\mathrm{vb}}-57^{\text {ra: }}$ Utrum ventus sit exalatio calida et sicca. Et arguitur quod non, quia non sit exalatio calida, quia si sic, sequeretur quod in temporibus

utrum talis mundus aggregatus ex quatuor corporibus simplicis sit unum ens continuum"; expl:: "Sed tamen non determinant sibi istam ex sua natura propria, sicut quod ignis est rotundus sive spericus, hoc est ratione continentis spere lune. Et sic est finis. Expliciunt questiones breves Alberti De celo et mundo".

13 Inc.: "Utrum sic esse in re sicut per propositionem significatur aliquid dictum ab ipsa re et eius propositione. Et arguitur primo quod sic, quia sic esse in re sicut per propositionem significatur potest esse quando nec res est nec eius propositio"; expl.: "quia omne ens quod non est chimera est de facto, sequitur quod res significata per istam propositionem nulla chimera est, etiam est de facto. Et sic patet questio".

14 Inc.: "Notandum est primo quod duplex est cyclus, quorum unus est solaris et alter lunaris. Cyclus lunaris est iste qui complet cursum suum in 19 annis"; expl.: "et hoc idem faciendum 
ventosis aer deberet esse calidus ...X... Ad ultimam dico quod non in vanum laborat ex quo aliam artem ignorat. Et sic est finis questionum tertii.

IV, ff. $57^{\text {ra }}-63^{\text {ra }}$ : Incipiunt quarti Metheororum questiones. Utrum tantum sint quatuor qualitates prime, scilicet caliditas, humiditas, frigiditas et siccitas. Et arguitur quod non, quia $\langle$ quod $\rangle$ per superhabundantiam dicitur, uni soli convenit ...X... Ad sextam dico quod in salamandra non dominatur ignis in quantitate nec etiam nutritur ab igne; sed tale animal non est ustibile ab igne; et ideo, quia non uritur ab igne, dicimus quod tale animal habitet in igne. Et sic est finis questionum Oren super Metheororum. Ad honorem Dei gloriosi. Amen. Deo gratias. Expliciunt questiones Metheororum. [alia manu]: anno Domini millesimo CCC sexagesimo nono finite sunt questiones Metheororum per manus illius qui scripsit eas, etc., et in vigilia Epiphanie per manus illius qui scripsit eas. Omnibus omnia non mea sompnia dicere possumus. Amen.

\section{Bibliography}

Catalogues: Von Scarpatetti, Gamper, and Stähli, Katalog der datierten Handschriften in der Schweiz: 1, 19o; Lohr, Aristotelica Helvetica, 78-79; Id., Latin Aristotle Commentaries. Medieval Authors 1: 256, 258; 2: 34 [here the manuscript is incorrectly dated 1469].

Literature: Burckardt, "Aus dem Umkreis der ersten Basler Universitätsbibliothek", 155-191, nr. 165; Michael, Johannes Buridan, 2: 636-637, 686; Streijger, Bakker, and Thijssen (eds.), John Buridan Quaestiones super libros De generatione et corruptione Aristotelis, 13.

\section{Berlin, Staatsbibliothek-Preußischer Kulturbesitz, lat. fol. 631, $f f \cdot 39^{r}-114^{r}(\mathrm{Be})$}

Paper; mm 250 × 190; ff. III+118+II; 1470

Date and origin. The colophons of the texts transmitted in this codex inform us that they were copied between 1470 and 1471: "Rescripte sunt hee questiones venerabilis magistri Nicolai Orem super libros Metheororum Aristotelis. Anno Domini 1470" (f. 114 ${ }^{\mathrm{r}}$ ); "finis anno 1471. He sunt questiones, puto magistri Christiani de Ackoy, super Sphera materialis" (f. $37^{\mathrm{v}}$ ). The origin of the manuscript is unknown, but various elements prove that it circulated in Central Europe. On f. $3^{8}$, we find a medieval note that has later been scraped. It refers to the apparition of a halo around the moon that could be seen from Basel: "anno 63 $[\ldots]$ apparuit Basilea halo circa lunam diu durans [...]”. On the second guard-

est de primis duabus litteris duarum sillabarum primarum cuiuslibet dictionis illorum versorum, et hoc non computetur pro littera". 
leaf, we find a modern possession mark: "Eduardo Machado, Hamburgo, Mayo 29, 1868". In 1903, the Prussian state library bought the manuscript from the antiquary J. Halle of Munich (see the note on the front cover: "acc. 1903, 177").

Codicology. Modern pasteboard binding covered with brown leather. Three modern paper guard-leaves numbered I-III at the beginning of the volume; at the end of the volume, we find three medieval paper guard-leaves numbered 115-117, followed by two modern guard-leaves numbered IV and v. The leaves are grouped primarily into quaternions: I (III-3 $)^{2+2}$; II $(4-11)^{4+4}$; III $(12-19)^{4+4}$; IV $(20-27)^{4+4}$; V $(28-35)^{4+4}$; VI $(36-43)^{4+4}$; VII $(44-51)^{4+4}$; VIII $\left(5^{2-59}\right)^{4+4}$; IX $(60-66)^{4+4}$; x $(67-74)^{4+4}$; XI $\left(75^{-82}\right)^{4+4}$; XII $\left(83^{-90}\right)^{4+4}$; XIII $(91-98)^{4+4}$; XIV $\left(99^{-106}\right)^{4+4}$; XV (107-114) ${ }^{4+4}$; XI $\left(115^{-I V}\right)^{2+2}$. Modern numbering in pencil in the upper outer margin. Two subsequent folios were numbered 62 and 62 bis. Watermark P similar to Piccard XII 641 (Freiburg im Breisgau, 1472). ${ }^{15}$

Content. The manuscript contains two texts: at $\mathrm{ff}^{\mathrm{r}} \mathrm{r}^{\mathrm{r}}-37^{\mathrm{v}}$, some Questions on Sacrobosco's De spera, which the colophon hesitantly ascribes to Christianus de Ackoy; ${ }^{16}$ at $\mathrm{ff} .39^{\mathrm{r}}-114^{\mathrm{r}}$, the second redaction of Oresme's Questions on Meteorology.

The Questions on Meteorology. The text, which is ascribed to Nicole Oresme in the colophon $\left(\mathrm{f} .144^{\mathrm{r}}\right)$, was copied by a German scribe in the fifteenth century. The handwriting, a bastarda, is regular and very readable. The text is laid out in one column with fifty-three lines per page. The first words of the questions are written in textualis. Some marginal notes by a different hand from that of the copyist are written alongside the last question of the third book, which discusses the artificial transformation of metals (for example, on the lower margin of f. $39^{r}$ we read: "Nihil agit ultra gradum suum proprium / Nihil agit ultra suam speciem / Activa non producunt formas substantiales / Nihil producit perfectius se ipso").

15 G. Piccard, Die Wasserzeichenkartei im Hauptstaatsarchiv Stuttgart, Stuttgart 1961-1997 (17 vols.).

16 Inc.: "Queritur circa initium Spere materialis primo utrum astronomia sit scientia. Et arguitur primo quod non, nam nulla scientia est prohibita; astronomia est prohibita; igitur astronomia non est scientia"; expl.: "sed potius debet dici obscuratio quam eclypsis Solis. Auctoritas post oppositum est pro conclusione responsali. Et hec de questione, et per consequens de omnibus questionibus Spere materialis". Colophon: "Finis anno 1471. He sunt questiones, puto magistri Christiani de Ackoy, supra Sphera materiali". Christianus de Ackoy, native from the diocese of Utrecht, obtained the degree of Master of Arts in Paris and subsequently enrolled in the Universities of Heidelberg (in 1387) and Cologne (in 1394). See Lohr, Latin Aristotle Commentaries, I.2. Medieval Authors M-Z: 97-98. Lohr only mentions Christianus of Ackoy's Questions on the Posterior Analytics and his treatise on the natural terms, but not the commentary on the Sphere transmitted in the Berlin manuscript. 
Incipit and explicit of the books

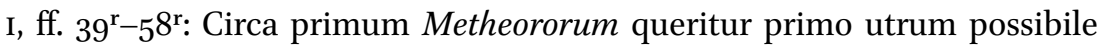
sit de impressionibus metheorologicis habere simul scientiam et opinionem. Et arguitur quod non, quia de impressionibus metheorologicis non contingit habere scientiam et opinionem; igitur questio falsa ...X... Propter hoc quia plures antiquorum crediderunt gallaxiam esse de natura elementari, propter eorum oppinionem ipse talem materiam hic tangit, etc. Explicit primus $\mathrm{Me}$ theororum.

II, ff. $59^{\text {r }}-68^{\text {v: }}:\langle C\rangle$ irca secundum Metheororum queritur primo utrum locus generationis pluviarum sit media regio aeris. Et arguitur quod non, nam nullum elementum debet generari extra suum locum naturalem ...X... Rationes patent in secundo articulo huius questionis, etc. Explicit secundum Metheororum, etc.

III, ff. $69^{\mathrm{r}}-105^{\mathrm{r}}$ : Circa tertium Metheororum queritur, secundum distinctionem istius totius in principio positam ab Alberto, utrum ventus sit exalatio calida et sicca. Et arguitur primo quod non sit exalatio calida et sicca ...X... Ad ultimam dico quod non in vanum laborant, ex quo aliam artem ignorant.

IV, ff. $105^{\mathrm{v}}-114^{\mathrm{r}}$ : $\langle\mathrm{C}\rangle$ irca quartum [corr. sup. lin. ex: secundum] Metheororum queritur primo utrum tantum quatuor sint qualitates prime, scilicet caliditas, frigiditas, humiditas, siccitas. Et arguitur primo quod non, quia quod per superhabundantiam dicitur, uni soli convenit ...X... Sed tale animal non est ustibile ab igne; et ideo, quia non uritur ab igne, dicimus quod tale animal habitet in igne, et non quod nutriatur ab igne nec in eo dominetur ignis, sed illo modo quo dictum est, scilicet quod sit inustibile ab ipso igne. Rescripte sunt hee questiones venerabilis magistri Nicolai Orem super libros Metheororum Aristotelis. Anno Domini 1470.

\section{Bibliography}

Catalogues: Ch. Lohr, "Aristotelica Berolinensia", Traditio 54 (1999), 353-423, at 378; Id., Latin Aristotle Commentaries. Medieval Authors, 1: 97-98; 2: 34.

Literature: Birkenmajer, Études d'histoire des sciences en Pologne, 182-183; Michael, Johannes Buridan, 2: 661, nr. 6; McCluskey, Nicole Oresme on Light, Color and the Rainbow, 81-82.

Paper; mm 305 $\times 105$; ff. III+208+II; 1421

Date and origin. The colophon of the Questions on Meteorology informs us that the text was copied in 1421 (f. $167^{\mathrm{v}}$ : "Expliciunt questiones Metheororum reverendi magistri Biridani finite ac peracte in festo sancti Mathie per me, per Petrum filium Francisci de Grinstad. Quarum conservator est reverendus 
magister Petrus dictus Culmach; Paulus vero de Tr. harum est possessor. Domo Domini 1421"). This part of the codex was copied in Göttingen, as stated in the colophon of f. 179": "Explicit liber De sensu et senssato [sic] et dicta per me Henricum Wetter [Wecter or Voecter] in Gottingen". The volume belonged to the library of the Collegium Porta Celi, founded at Erfurt University by Amplonius Rating de Berka in 1433, and was registered under the signature " 7 " in Amplonius's catalogue. ${ }^{17}$

Codicology. Wooden binding covered with brown leather, restored in 1974. Two intact clasps attached to the back cover. Two modern paper guard-leaves, followed by a medieval parchment guard-leaf. The first guard-leaf is glued to the inside cover. On the recto of the parchment guard-leaf, a medieval hand has written in black ink: "liber librarie collegii porte celi" and "septimus naturalis in novis". Another medieval hand has written in red ink: "liber collegii porte celi". On the verso of the same guard-leaf, a third medieval hand has written: "septimus philosophie naturalis in novis Collegii Porte Celi". There is also a table of contents by the same hand: "In isto volumine continentur: Questiones Parvorum Naturalium reverendi magistri Marsilii de Inghen; Questiones Meteororum reverendi magistri Biridani; Commentum Parvorum Naturalium reverendi magistri Marsilii; Problemata Aristotelis principis philosophorum; item quod quatuor modis febris cotidiana solet evenire". The volume consists of three parts, of different sizes with different kinds of paper: I (ff. 1-63); II (ff. 64-167); III (168-208). The leaves are bound as follows: I (1-13 $)^{6+(6+1)}$; II (14$25)^{6+6}$; III $(26-37)^{6+6}$; IV $(38-49)^{6+6} ; \mathrm{V}\left(5^{\mathrm{O}-63}\right)^{7+7}$; VIII $(64-75)^{6+6} ;(76-87)^{6+6}$; $(88-99)^{6+6} ;(100-111)^{6+6} ;(112-123)^{6+6} ;(124-135)^{6+6} ;(136-147)^{6+6} ;(148-159)^{6+6}$; $(160-167)^{6+(6-4)} ;(168-177)^{5+5} ;(178-189)^{6+6} ;(190-205)^{8+8} ;(206-208)^{(3-2)+(3-1)}$. At the end of the volume, we find two modern paper guard-leaves; the second one is glued to the inside back cover, in the same manner as at the beginning of the volume. The first four fascicules of the second part contain signatures in red ink, in the central lower margin: f. $64^{\text {r }}$ (i); f. $76^{\text {r }}$ (ii); f. $88^{\text {r }}$ (iii); f. $100^{r}($ iiii). Ff. $61^{\mathrm{v}}-63^{\mathrm{r}}$ are blank. Modern foliation in pencil in the upper outer margin. Two consecutive leaves were numbered 196; for this reason, an additional foliation starts with the second leaf numbered 196, to correct the previous one.

Content. This manuscript contains Marsilius of Inghen's commentaries on the Parva naturalia; ${ }^{18}$ a set of "problems" concerning the body of animals,

17 G. Oergel, "Das Collegium zur Himmelspforte während des Mittelalters", Mitteilungen des Vereins für Geschichte und Altertumskunde von Erfurt 19 (1898), 19-114.

18 Ff. $\mathrm{r}^{\mathrm{ra}}-33^{\mathrm{rb}}$ : Questiones super librum De sensu et sensato; ff. $33^{\mathrm{va}}-38^{\mathrm{va}}$ : Questiones super

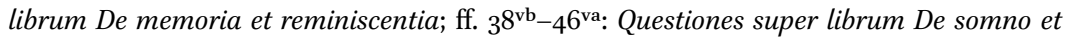

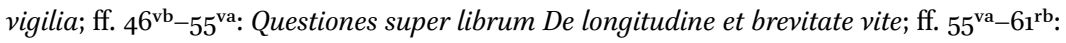


which is partially taken from Aristotle's Problemata, ${ }^{19}$ a note on four different kinds of fever ${ }^{20}$ and a set of questions on Aristotle's Meteorology $\left(f f .64^{\mathrm{ra}}-167^{\mathrm{rb}}\right)$, which the colophon ascribes to John Buridan.

The Questions on Meteorology. Although the colophon ascribes the whole commentary to Buridan, this only applies to the first three books, the fourth being by Oresme. ${ }^{21}$ The text is laid out in two columns of about forty-five lines each. The ink is brown and the decoration has not been completed, as the rubrics stop on $\mathrm{f} .68^{\mathrm{va}}$ and the incipits of the questions in textualis only reach question I.2, on f. $65^{\mathrm{vb}}$. Only the incipit of the first book has been copied: in some other cases, the space intended for this purpose has been left blank (see for example f. 121 ${ }^{\mathrm{va}}$ ).

Questiones super librum De inspiratione et respiratione (unfinished); $\mathrm{ff} .168^{\mathrm{ra}}-179^{\mathrm{va}}$ : Expositio libri De sensu et sensato; ff. $179^{\mathrm{vb}}-183^{\text {ra }}$ : Expositio libri De memoria et reminiscentia; ff. $183^{\text {rb }}-189^{\text {va: }}$ Expositio libri De somno et vigilia; ff. $189^{\text {va }}-193^{\text {va: }}$ Expositio libri De longitudine et brevitate vite; ff. $191^{\mathrm{va}}-193^{\mathrm{ra}}$ : Expositio libri De iuventute et senectute; $\mathrm{ff} .193^{\mathrm{ra}}-194^{\mathrm{rb}}$ : Expositio libri De respiratione et inspiratione; ff. $194^{\mathrm{rb}}-194^{\mathrm{vb}}$ : Expositio libri De morte et vite; ff. $194^{\mathrm{vb}}-195^{\mathrm{rb}}$ : Expositio libri de motu cordis; $\mathrm{ff} .195^{\mathrm{rb}}-195^{\mathrm{vb}}$ : Expositio libri De motibus animalium. Colophon: "Explicit liber De sensu et senssato [sic] et dicta per me, Henricum Wetter in Gottingen". On Marsilius of Inghen's commentaries on Aristotle's Parva naturalia see S. Ebbesen, C. Thomsen-Thörnqvist, and V. Decaix, "Questiones on De sensu et sensato, De memoria, and De somno et vigilia. A Catalogue", Bulletin de Philosophie Médiévale 57 (2015), 59-116, esp. 85-86 (De sensu et sensato), 95 (De memoria), 113-114 (De somno et vigilia).

19 Inc.: "Omnes homines naturaliter scire desiderant, scribit philosophorum princeps"; expl.: "cognitis et solutis propleumatibus de partibus corporis humani ex variis Aristotelis et aliorum philosophorum et pariter medicorum codicibus lucide collectis et extractis, hic iam consequenter aliqua propleumata generalia, attamen valentia et utilia, sunt subiungenda". L. Thorndike, and P. Kibre, A Catalogue of Incipits of Scientific Writings in Latin, Cambridge (MA), 1963 (The Medieval Academy of America, 29), col. 986.

$20 \quad$ Inc.: "febris cottidiana quattuor modis solet evenire"; expl.: "sudorem emittat de mane". See Thorndike and Kibre, A Catalogue of Incipits of Scientific Writings in Latin, col. 551.

21 As I have pointed out elsewhere (Panzica, "Nicole Oresme à la Faculté des Arts de Paris", 38), this ascription caused some confusion in catalogues and modern inventories, which often ascribe the whole text to Buridan: W. Schum, Beschreibendes Verzeichnis der Amplonianischen Handschriften-Sammlung zu Erfurt, Berlin 1887, 230-231; E. Faral, "Jean Buridan: notes sur les manuscrits, les éditions et le contenu de ses ouvrages", Archives d'histoire doctrinale et littéraire du Moyen Âge 35 (1960), 1-53, esp. 21, Ch. Lohr, "Medieval Latin Aristotle Commentaries. Authors: Jacobus-Johannes Juff", Traditio 26 (1970), 135-216, at 172, M. Markowski, Repertorium commentariorum medii aevi in Aristotelem Latinorum quae in Bibliotheca Amploniana Erffordiae asservantur, Wrocław 1987, 182. Birkenmajer (Études d'histoire des sciences en Pologne, 181-182) and McCluskey (Nicole Oresme on Light, Color and the Rainbow, 96) correctly distinguish the first three books, which should be ascribed to Buridan, from the fourth book, which is by Oresme. 
Incipit and explicit of the books

Prol:: Ut habetur in prohemio De anima, constat quod scientiam libri $\mathrm{Me}$ theororum valde reputare debemus aliis nobiliorem et super cetera appetibilem; opera namque metheoroloyca inter cetera nobis apparentia sunt mirabiliora.

I, ff. $64^{\mathrm{rb}}-1 \mathrm{O} 4^{\mathrm{rb}}$ : Queritur primo utrum de impressionibus metheoroloicis sit tradenda scientia naturalis distincta a scientia De celo et mundo et De generatione et corruptione, De mineralibus et De anima et animatis. Arguitur primo quod non sit scientia de eis, quia non est scientia de singularibus, contingentibus et potentibus aliter se habere ...X... Veniunt enim alia mineralia de alio loco ad illum. Et sic sit finis huius questionis et primi libri.

II, ff. $104^{\mathrm{rb}}-121^{\mathrm{va}}$ : Circa secundum librum Metheororum queritur primo de perpetuitate vel generatione maris, scilicet utrum mare fuit perpetuum vel aliquando factum. Arguitur quod non fuit perpetuum ...X... Solutiones aliarum rationum satis haberi possunt ex predeterminatis. Et sic patet questio, et per consequens secundus liber.

III, ff. $121^{\text {va }}-158^{\text {va }}$ : Circa principium tertii libri primo notandum, et verum est, quod ab antiquo solet istum totum librum Metheororum dividi in quatuor partes ...X... Sive lapidibus, sive plantis, sive avibus, sive earum plumis et metallis. Et sic finitum tertii libri [sic] Metheororum, date a reverendo magistro Biridano.

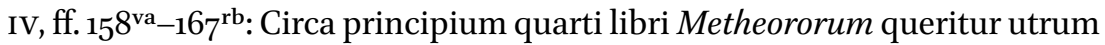
tantum sint quatuor qualitates prime, scilicet caliditas, humiditas, frigiditas et siccitas. Arguitur quod non ...X... Ad sextam dico quod in salamandra non duratur ignis in quantitate nec ibi nutritur ab igne; sed tale animal non est ustibile ab igne; et ratio quia non uritur ab igne, dicimus quod tale animal non est ustibile ab igne. Et sic patet questio, etc.

\section{Bibliography}

Catalogues: W. Schum, Beschreibendes Verzeichnis der Amplonianischen Handschriften-Sammlung zu Erfurt, Berlin 1887, 230-231; Bénédictins du Bouveret, Colophons de manuscrits occidentaux des origines au XVI ${ }^{e}$ siècle, Fribourg (Switzerland) 1979 (Spicilegii Friburgensis Subsidia) (6 vols.), 5: 87; M. Markowski, Repertorium commentariorum medii aevi in Aristotelem Latinorum quae in Bibliotheca Amploniana Erffordiae asservantur, Wrocław 1987, 70, 182; Lohr, Latin Aristotle Commentaries, I.2. Medieval Authors M-Z: 257; 2: 34 .

Literature: Birkenmajer, Études d'histoire des sciences en Pologne, 181-182; McCluskey, Nicole Oresme on Light, Color and the Rainbow, 96; S. Bages, Les Questiones super tres libros Metheororum Aristotelis deJean Buridan:étude suivie de l'édition du livre I, Thèse de doctorat de l'École des Chartes, 1986 (2 vols.), 1: 148-150; Panzica, "Nicole Oresme à la Faculté des Arts de Paris", 35. 


\section{Kassel, Universitätsbibliothek-Landesbibliothek und Murhardsche} Bibliothek, $2^{\circ}$ Phys. et hist. nat. 12, ff. $1^{\nu_{-107}}$ (Ka)

Paper; mm $220 \times 331$;f. $203 ; 1424$

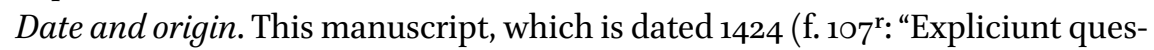
tiones Orem, reverendi magistri Wilhelmi super Metheororum. Anno domini millesimo quadragentesimo vicesimo quarto, sabbato post festum sancti Egidii"), was owned by the library of the Augustinian Canons of Fritzlar and came into the possession of the Murhardsche Bibliothek of Kassel in 1804.

Codicology. Wooden binding covered with leather. The manuscript contains 203 paper leaves grouped as follows: I $(1-12)^{6+6}$; II $\left(13^{-24}\right)^{6+6}$; III $\left(25^{-}\right.$ $\left.3^{6}\right)^{6+6} ; \mathrm{IV}(37-48)^{6+6} ; \mathrm{V}(48-6 \mathrm{o})^{6+6} ; \mathrm{VI}(61-72)^{6+6} ; \mathrm{VII}\left(73^{-84}\right)^{6+6} ; \mathrm{IX}\left(85^{-96}\right)^{6+6}$; X $(97-108)^{6+6}$; XI $(109-120)^{6+6}$; XII $\left(121-13^{2}\right)^{6+6}$; XIII $\left(133^{-144}\right)^{6+6}$; XIV $\left(145^{-}\right.$ $156)^{6+6}$; XV $(157-166)^{5+5}$; XVI $(167-179)^{(1+6)+6}$; XVII $(180-191)^{6+6}$; XVIII (192$203)^{6+6}$. Modern page numbering in pencil in the outer margin. Signatures in the upper margin of the recto leaves: f. 61 (6us); f. 73 (7us); f. 85 (octavus); f. 97 (nonus).

Content. In addition to Oresme's Questions on Meteorology $\left(\mathrm{ff} .2^{\mathrm{ra}}-1 \mathrm{O} 7^{\mathrm{rb}}\right)$, this manuscript contains an incomplete set of anonymous questions on Aristotle's Physics $\left(109^{\mathrm{ra}}-198^{\mathrm{rb}}\right)$. These questions are preceded by a table of contents of the questions for the first three books (ff. $\left.107^{\mathrm{vb}}-108^{\mathrm{ra}}\right) \cdot{ }^{22}$

The Questions on Meteorology. The commentary is ascribed to Guillaume Oresme in the colophon $\left(\mathrm{f} .107^{\mathrm{r}}\right) \cdot{ }^{23}$ The text, copied in a single hand, is laid out

The first book contains 24 questions; the second book, 12 questions; the third book, 19 questions; the fourth, contains 15 questions; the fifth book, 10 questions; the sixth book, 8 questions; the seventh book, 6 questions; the eighth book, 5 questions. Some of the questions listed in the table are: I.1, Utrum phylosophia naturalis sit considerativa de omnibus rebus mundi; I.2, Utrum totali scientie naturali assignandum est unum subiectum; I.3, Utrum ens mobile sit subiectum scientie libri primi [...]; II.1, Utrum res artificialis sit distincta a re naturali; II.2, Utrum differentia quam ponit Philosophus inter naturalia ex una parte et artificialia ex altera sit bona; II.3, Utrum figura sit distincta a re figurata [...]; III.1, Utrum, ignorato motu, necesse sit ignorare naturam; III.2, Utrum in alteratione, preter alterabile et qualitatem que acquiritur, sit ponendus fluxus distinctus; III.3, Utrum qualitates contrarie possunt se simul compati in aliquo subiecto.

23 Very little is known about Guillaume Oresme, who was a theologian, member of the Collège of Navarre from 1352: J. de Launoy, Regii Navarre Gymnasii Parisiensis Historia, Paris 1677 (2 vols.), 1: 93; F. Meunier, Essai sur la vie et les ouvrages de Nicole Oresme, Paris 1857 , 10. He is mentioned in a bull of 1367 , which informs us that at that time he held a bachelor in Theology and was canon of Bayeux: H. Denifle and E. Chatelain, Chartularium Universitatis Parisiensis, 1200-1452, Paris, 1889-1897 (4 vols.), 2 (1891), 641, n. 3 ("Guillelmo Oresme, bacallario in theologia, canonico Baiocensi"). Guillaume Oresme is the author of a translation of Ptolemy's Quadripartitum prepared at the request of Charles v and transmitted in ms. Paris, Bibliothèque Nationale de France, franç. 1348. 
in two columns of about fifty lines each. On f. $1^{\mathrm{r}}$, there is a sort of draft of the first question, which stops after the words: "ex parte ipsius opinantis". The handwriting is not as polished as that of the following text. On f. $\mathrm{r}^{\mathrm{r}}$, we find many pen testing marks ("amice benignissime contrariam doctrinam exquiris fraternitatem; ave maria, ave maria gratia"). After the table of contents on $f .1^{v}$, the text starts from scratch on f. $2^{r}$. The words that mark the beginning of the books are in textualis and are placed so as to form a square. Rubrics and pilcrows in red. Marginal notes in red or brown ink. Some discontinuous notes refer to the content of the text (see for example f. $3^{8}$, marg. sup.: "nota distinctionem marium et quare unum sit salsum et aliud non"). The initials of the words that introduce new paragraphs are marked by a red stroke. The decoration is incomplete: on f. $2^{\mathrm{vb}}$, for instance, the space left for the title of the question has been left blank; similarly, on f. $92^{\text {ra }}$, the space for the initial words of the fourth book has been left blank. On f. $1^{\mathrm{v}}$, we find a table of contents for the first three books; the table of contents of the fourth book can be found on $\mathrm{f} .107^{\mathrm{va}}$.

Incipit and explicit of the books

I, ff. $2^{\text {ra }}-24^{\text {vb: }}$ Circa initium primi libri Metheororum queritur primo utrum possibile sit de impressionibus metheorologicis simul habere scientiam et opinionem. Et arguitur primo quod non, quia de impressionibus metheorologicis non contingit habere scientiam et opinionem, ergo questio falsa ...X... Ad quartam: 'si galaxia non esset de natura celi, tunc de ea non esset determinandum in isto libro', concedo. Sed tamen Aristoteles determinavit de ea hic propter hoc quia plures antiquorum crediderunt quod galaxia esset de natura elementari. Et sic est finis questionum primi libri. Et sic est finis primi libri Metheororum. Sequuntur questiones Metheororum libri secundi.

II, ff. $25^{\text {ra_va: }}\langle$ C $\rangle$ irca initium secundi libri Metheororum queritur primo utrum locus generationis pluvie sit media regio aeris. Et arguitur quod non: nul-

On the ascription of this translation see M. Lejbowicz, "Guillaume Oresme, traducteur de la Tétrabible de Claude Ptolémée”, Pallas 30 (1983), 107-133. The edition of this translation was prepared by J.W. Gossner, Le Quadripartit Ptholomee, unpublished Ph.D. dissertation, Syracuse University 1951. Menut has written that "well authenticated works of Nicole have been occasionally attributed to Guillaume both in Ms. and in printed editions" (A.D. Menut (ed.), Maistre Nicole Oresme: Le livre de Éthiques d'Aristote, Published from the Text of MS. 2902, Bibliotheque Royale de Belgique, with a Critical Introduction and Notes, New York 1940, 11, fn. 8). Two manuscripts transmitting Nicole Oresme's De communicatione ydiomatum ascribe the text to Guillaume Oresme: Erfurt, Universitätsund Forschungsbibliothek, Dep. Erf. CA $4^{\circ}{ }^{15}$, ff. $83^{\mathrm{v}}-92^{\mathrm{v}}$ (Colophon: "Explicit tractatus magistri Guillemi Horem De communicatione ydiomatum") and Toulouse, Bibliothèque d'Étude et du Patrimoine, ms. 246, ff. $219^{\mathrm{v}}-225^{\mathrm{v}}$ (Initium: "Incipit tractatus De communicatione ydiomatum editus a magistro Guillelmo Oreme, doctore in theologia Parisiensi"). 
lum elementum debet generari extra locum sibi naturalem ...X... Ad rationes ante oppositum patet ex secundo articulo. Et sic est finis questionum secundi Metheororum.

III, ff. $39^{\mathrm{vb}-91^{\mathrm{vb}}}$ : $\langle\mathrm{C}\rangle$ irca tertium librum Metheororum queritur utrum ventus sit exalatio calida et sicca. Et arguitur primo quod non sit exalatio calida, nam si sic, sequeretur quod temporibus ventosis aer debet esse calidus ...X... Ad ultimam dico quod non in vanum laborant, ex quo aliam artem ignorant. Et sic patet questio. Et sic est finis questionum tertii libri Metheororum, de quo laudetur Sancta Trinitas in secula seculorum. Amen.

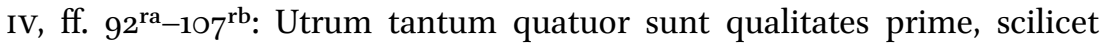
caliditas, humiditas, siccitas et frigiditas. Et arguitur primo quod non, quia quod per habundantiam dicitur, uni soli rei convenit ...X... Et quia non uritur ab igne, dicimus quod ipsum habitet in igne. Et sic est finis.

\section{Bibliography}

Catalogues: Lohr, Latin Aristotle Commentaries, I.2. Medieval Authors M-Z: 34 .

Literature: McCluskey, Nicole Oresme on Light, Color and the Rainbow, 89-9o.

\section{$6 \quad$ Klagenfurt, Bischöfliche Bibliothek, $x_{X X I} b_{5}, f f .1^{r}-124^{r}(\mathrm{Kl})$}

Paper; mm 290 × 200; ff. 168; ca. 1395-1405

Date and origin. Very little is known about this manuscript. According to Michael, it comes from southern Germany or Carinthia. ${ }^{24}$ The codex is mentioned in a manuscript catalogue of Gurk's diocesan library from about 1700 under the signature $138 .{ }^{25}$ The watermark, a long bell with three parallel clips, which appears in fascicules X-XII, was particularly widespread between the last decade of the fourteenth and the first years of the fifteenth century. ${ }^{26}$

Codicology. Wooden binding covered with leather. A parchment sheet glued to the inside front cover contains the table of contents of Oresme's Questions. The leaves are grouped mainly in senions, according to the following formula: I $(1-12)^{6+6}$; II $\left(13^{-24}\right)^{6+6}$; III $\left(25^{-36}\right)^{6+6}$; IV $(37-48)^{6+6}$; V $(49-60)^{6+6}$; VI $(61-$ $72)^{6+6}$; VII $\left(73^{-84}\right)^{6+6}$; VIII $\left(85^{-96}\right)^{6+6}$; IX $(97-106)^{5+5}$; x (107-118) ${ }^{6+6}$; XI (119$124)^{3+3}$; XII $\left(125^{-136}\right)^{6+6}$; XIII $(137-148)^{6+6}$; XIV $\left(149^{-161}\right)^{6+6}$; XV $(162-168)^{4+4}$.

\footnotetext{
24 Michael, Johannes Buridan, 2: 741.

25 Catalogus super libros bibliothecae episcopatus Gurcensis cum praevia instructione ad inveniendum quemvis librum in promptum. This catalogue is now preserved under the signature xxx b 11 in the Klagenfurt Diocesan Library. See Menhardt, Handschriftenverzeichnis der Kärntner Bibliotheken 1: Klagenfurt, Vienna 1927 (Handschriftenverzeichnisse Österreichischer Bibliotheken 1: Kärnten), 33-34.

26 See the database Wasserzeichen des Mittelalters, http://www.wzma.at/29o1.
} 
Another parchment leaf is glued to the inside back cover. This leaf contains a fragment from Alanus of Lille's De planctu nature. ${ }^{27}$ Signatures: f. $25^{\mathrm{r}}$ (3us Metheororum), f. $36^{\mathrm{v}}$ (3us), f. $48^{\mathrm{v}}$ (4us), f. $60^{\mathrm{v}}$ (5us), f. $72^{\mathrm{v}}$ (6us), f. $83^{\mathrm{v}}$ (7us), f. $96^{\mathrm{v}}$ (8us), f. $106^{\mathrm{v}}$ (gus), f. $118^{\mathrm{v}}$ (1ous), f. $123^{\mathrm{v}}$ (11us), f. $13^{\mathrm{v}}$ (primus). Catchwords: f. $36^{\mathrm{v}}$, f. $48^{v}$, f. $72^{v}$, f. $83^{v}$, f. $96^{v}$, f. $106^{v}$. Medieval foliation in the outer upper margin of the recto leaves. The foliation skips from 159 to 161

Content. The codex contains Oresme's Questions on Meteorology $\left(\mathrm{ff} .1^{\mathrm{v}}-124^{\mathrm{r}}\right)$ and John Buridan's Questions on the Parva naturalia (ff. $\left.125^{\mathrm{rb}}-168^{\mathrm{vb}}\right) .{ }^{28}$

The Questions on Meteorology. The commentary, which is anonymous, is laid out in two columns of about forty lines each. The text was copied by two scribes. The first one copied ff. $1^{\mathrm{v}}-41^{\text {ra }}(1.28) ; 107^{\text {ra }}-108^{\text {ra }}(1.2) ;$ ff. $112^{\text {ra }}-124^{\text {rb }}$; the second one, which has a curvier handwriting, copied ff. $41^{\text {ra }}(1.29)-106^{\text {vb }}$;f. $108^{\text {ra }}(\mathrm{l} .3)-$ $111^{\mathrm{vb}}$.

A table of contents of the Questions is copied on a parchment sheet glued to the inner front cover. This sheet is numbered 119 in the upper margin. On f. 119, we find an alphabetical index that presents the content of the questions in alphabetical order (for example: "aqua an naturaliter ascendat ad orificia fontium", "animalia habitantia in locis calidis, an sint"). It is interesting to notice that the subjects listed do not always match the titles of the questions. In compiling this alphabetical list, the copyist therefore wished to provide the reader with as detailed an index as possible.

In the upper margin, we find a medieval numbering in brown ink. In some cases, the first words and the structural parts of the questions are copied in textualis (see for instance f. $7^{\mathrm{rb}}$ and f. $28^{\mathrm{vb}}$ ). More often, however, the space set aside for these words has been left blank (f. $7^{\mathrm{v}}$ and $\mathrm{f} .8^{\mathrm{r}}$ ). The first words of the text $(\langle\mathrm{C}\rangle$ irca initium libri Metheororum Aristotelis queritur questio talis) are placed so as to form a square of a width of about seventeen lines. The decoration is incomplete: the space intended for the initials of the books has been left blank (see, for example, the incipit of the first book on f. $1^{\text {ra }}$ and the explicit of the second book on f. $33^{\mathrm{rb}}$ ).

Incipit and explicit of the books

I, ff. $1^{\text {va }}-33^{\text {rb }}:\langle\mathrm{C}\rangle$ irca initium libri Metheororum Aristotelis queritur questio talis: utrum possibile sit de impressionibus metheroloicis [sic] simul habere scientiam et opinionem. Et arguitur primo quod non, quia de impressionibus

27 The fragment, written in two columns, begins with the words: "melius esse producitur per me homo procreatur ad mortem per ipsum recreatur" and ends with the words: "falsitate vesperascit occasum".

28 Ff. $125^{\mathrm{rb}}-143^{\mathrm{vb}}$ : Questiones in librum De sensu et sensato; $\mathrm{ff.} 143^{\mathrm{vb}}-146^{\mathrm{va}}$ : Questiones in li-

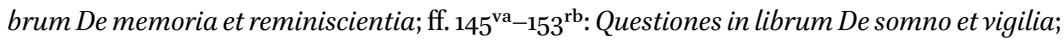


metholoycis $[s i c]$ non contingit habere scientiam nec opinionem; ergo questio falsa ...X... Ad quartam: 'si galaxia esset de natura celi, tunc de ea non esset determinandum in isto libro', concedo tamen quod Aristoteles determinat de ea propter quod quia plures antiquorum crediderunt galaxiam esse de natura elementari. Et sic patet questio. Hoc de isto primo libro. Deo laus.

II, ff. $33^{\text {rb }}-40^{\text {va: }}:\langle\mathrm{C}\rangle$ irca librum secundum Metheororum Aristotelis queritur questio prima, circa secundum huius, secundum distinctionem in principio positam ab Alberto, et est questio ista: utrum locus generationis pluvie sit media regio aeris. Et arguitur primo quod non ...X... Ad rationes in oppositum patet in secundo articulo.

III, ff. $4 \mathrm{O}^{\text {va }}-109^{\text {va }}$ : $\langle\mathrm{C}\rangle$ irca tertium, secundum distinctionem illius libri totius in principio positam ab Alberto, sit questio prima: utrum ventus sit exalatio calida et sicca. Et arguitur primo quod non sit exalatio calida ...X... Ad ultimam dico quod non in vanum laborant, ex quo aliam artem ignorant.

IV, ff. $109^{\mathrm{va}}-124^{\mathrm{r}}$ : $\langle\mathrm{C}\rangle$ irca principium istius quarti queritur primo utrum tantum sint quatuor qualitates prime, scilicet caliditas, humiditas, frigiditas, siccitas. Et arguitur quod non, quia quod per superhabundantiam dicitur, uni soli convenit ...X... Ad quartam dico quod in salamandra non dominatur ignis in quantitate; sed tale animal non est ustibile $a b$ igne nec etiam nutritur $a b$ igne; ratio huius quia non uritur ab igne, dicimus quod tale animal habitat in igne. Hoc de questione et per consequens de omnibus. Ecce finis.

\section{Bibliography}

Catalogues: H. Menhardt, "Die Handschriftensammlung der bischöflichen Bibliothek in Klagenfurt", Zentralblatt für Bibliothekswesen 39 (1922), 363-381, esp. 375; Id., Handschriftenverzeichnis der Kärntner Bibliotheken 1: Klagenfurt, 68 [here Oresme's Questions are attributed with doubt to Albert the Great]; M. Markowski, Repertorium commentariorum medii aevi in Aristotelem Latinorum qui in bibliothecis austriacis: Admont, Furt bei Göttweig, Graz, Heiligenkreuz, Klagenfurt, Klosterneuburg, Kremsmünster, Linz, Melk, Salzburg, Sankt Florian, Vorau, Zwettl asservantur, Krakow 2008, 65, 196; Lohr, Latin Aristotle Commentaries, I.2. Medieval Authors M-Z: 26o-262; 2: 35 .

Literature: McCluskey, Nicole Oresme on Light, Color and the Rainbow, 90-91; Michael, Johannes Buridan, 2: 741, 749, 755, 763, 770.

ff. $153^{\text {rb }}-157^{\mathrm{va}}$ : Questiones in librum De longitudine et brevitate vite; $\mathrm{ff} .157^{\mathrm{va}}-168^{\mathrm{vb}}$ : Questiones in libros De morte et vita, De respiratione, De iuventute et senectute. See Ebbesen, Thomsen-Thörnqvist, Decaix, "Questiones", 82, 94, 112. 


\section{$7 \quad$ Kraków, Biblioteka Jagiellońska, cod. $749, f f \cdot 59^{v}-10^{v}(\mathrm{Kr})$}

Paper; mm 300 × 215; ff. 110 + III; ca. 1360-1370

Date and origin. This manuscript comes from the University of Prague, as stated by the colophon on f. $59^{\text {r: }}$ "Expliciunt questiones De generatione et corruptione Byrydani magistri Parariensis [sic] Prage reportate". The majority of the texts contained in this manuscript were copied by a certain Iohannes (see below the colophon of Oresme's Questions on Meteorology). The watermarks allow us to date the manuscript to the 137os.

Composition. See the modern catalogue, $5,293 .{ }^{29}$

Content. The manuscript contains some commentaries on the Aristotelian natural books by Parisian masters of the fourteenth century: Albert of Saxony's Questions on De celo (ff. $1^{\mathrm{r}}-42^{\mathrm{v}}$ ); John Buridan's redactio B of the Questions on De generatione et corruptione (ff. $43^{\mathrm{r}}-59^{\mathrm{r}}$ ), as well as the second redaction of Oresme's Questions on Meteorology (ff. $\left.59^{\mathrm{r}}-110^{\mathrm{r}}\right)$.

The Questions on Meteorology. The colophon ascribes the text to Nicole Oresme: "Expliciunt questiones Metheororum magistri Nicholai dicti cognomine Orem, finite per manus Iohannis et reportate ante festum Sancti Galli" (f. 110 ${ }^{\text {va }}$ ). The text is laid out in two columns of about sixty-five lines each. The handwriting is tiny and compact; the ink is brown. From f. $60^{\text {rb }}$ onwards, we notice an abrupt change in ink. The copyist, who stopped writing at $f .6 \circ^{\text {ra }}$ and restarted on f. $6 \mathrm{o}^{\mathrm{rb}}$, completely skipped the main body of question I.2 (Utrum impressiones metheorologice fiant secundum naturam inordinatiorem quam sit natura celi) jumping directly from the contrary arguments (f. $\left.6 \mathrm{o}^{\mathrm{ra}}\right)$ to the answer. On f. $59^{\text {va }}$, some space has been left for the initial that should have introduced the text. The titles of the questions are in textualis. The folios have been numbered with a pencil by a modern hand. Another modern hand has numbered the questions with a pencil.

Incipit and explicit of the books

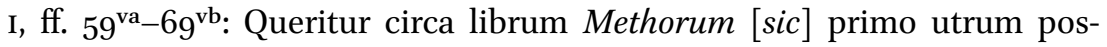
sibile sit de impressionibus metlogicis [sic] habere scientiam et opinionem. Et arguitur quod non, quia de eis non convenit habere scientiam nec opinionem; ergo questio falsa ...X... Ad quartam: 'si galaxia esset de natura celi', etc., concedo, tamen Aristoteles determinat de ea propter hoc quia [69 $\left.{ }^{\mathrm{vb}}\right]$ plures antiqui crediderunt galaxiam esse de natura elementari. Et sic patent questiones primi libri.

II, ff. $69^{\text {vb }}-76^{\text {va }}:\langle T\rangle$ unc restat tractare questiones secundi Metheororum. Utrum locus generationis pluvie sit media regio aeris. Et arguitur quod non: 
nullum elementum debet generari extra locum sibi naturalem ...X... Oppositum patet ex secundo articulo. Et sic est finis secundi libri Metheororum.

III, ff. $76^{6^{\mathrm{va}}-101^{\mathrm{rb}}}$ : $\langle\mathrm{T}\rangle$ unc secuuntur questiones tertii libri Metheororum. Utrum ventus sit exalatio calida et sicca. Et arguitur quod non sit exalatio calida, quia si sic, sequitur quod in temporibus ventosis aer deberet esse calidus ...X... Ad ultimam dico quod non in vanum laborant, ex quo aliam artem ignorant.

IV, ff. $101^{\mathrm{rb}}-11 \mathrm{O}^{\mathrm{v}}:\langle\mathrm{Q}\rangle$ ueritur circa quartum librum et ultimum Metheororum. Queritur circa quartum librum utrum sunt tantum quatuor qualitates prime, scilicet caliditas, humiditas, frigiditas et siccitas. Et arguitur primo quod non, quia quod per superhabundantiam dicitur, uni soli convenit ...X... Sed tale animal non est combustibile ab igne et ideo, quia non uritur ab igne, dicimus quod ipsum habitat in igne. Et sic est finis, etc. Expliciunt questiones Metheororum magistri Nicolai dicti cognomine Orem. Finite per manus Iohannis et reportate ante festum sancti Galli [16th October]. Laus Christo sit etc.

\section{Bibliography}

Catalogues: W. Wisłocki, Catalogus codicum manuscriptorum Bibliothecae Universitatis Jagellonicae Cracoviensis, Krakow 1877 (2 vols.), 1: 222; M. Kowalczyk [et al.], 292-294; M. Markowski, and Z. Włodek, Repertorium commentariorum medii aevi in Aristotelem Latinorum quae in Bibliotheca Jagellonica Cracoviae asservantur, Wrocław 1974, 59; Lohr, Latin Aristotle Commentaries, I.2. Medieval Authors M-Z: 40, 256; 2: 35 .

Literature: Birkenmajer, Études d'histoire des sciences en Pologne, 188-189; Michael, Johannes Buridan, 2: 638-639; Streijger, Bakker, and Thijssen (eds.), John Buridan Quaestiones super libros De generatione et corruptione Aristotelis, 15-16; M. Markowski, Burydanizm w Polsce w okresie przedkopernikańskim: studium z historii filozofii nauk ścistych na Uniwersytecie Krakowskim w XV wieku, Wrocław 1971, 404; A. Panzica, “Commenter les Météorologiques à l'Université de Cracovie", 8o-82.

\section{$8 \quad$ Kraków, Biblioteka Jagiellońska, cod. $751, f f \cdot 3^{r}-53^{r}\left(\mathrm{Kr}_{1}\right)$}

Paper; mm 275× 220; 15o ff.; ca. 136o-1370

Date and origin. The watermarks allow us to date this manuscript to around 1360-1370. Some notes in Czech prove its Bohemian origins (see f. 114 ${ }^{\mathrm{v}}$ ). The

codicum manuscriptorum medii aevi latinorum qui in Bibliotheca Jagellonica Cracoviae asservantur, 5, Numeros continens inde a 668 usque ad 771, Wrocław/Warsaw 1992, 292-294, at 293 . 
manuscript was brought to Krakow in the second quarter of the fifteenth century by a Polish scholar. Starting from 1462, it belonged to master Iacobus Boksicze, as witnessed by the mark of possession on the inside cover: "Liber magistri Boxicze". ${ }^{30}$

Composition. See Kowalczyk [et al.], Catalogus, 5, 299.

Content. The manuscript mainly contains commentaries on the Aristotelian corpus by Parisian masters of the fourteenth century: a fragment from Albert of Saxony's Questions on Meteorology (f. $2^{\text {ra }}{ }^{\mathrm{vb}}$ );1 $;^{31}$ the second redaction of Oresme's Questions on Meteorology (ff. $3^{\mathrm{ra}}-53^{\mathrm{rb}}$ ); the short version of Buridan's Questions on De anima (ff. $54^{\mathrm{ra}}-73^{\mathrm{vb}}$ ); Albert of Saxony's Questions on De celo (ff. $74^{\text {ra }}-124^{\text {ra }}$ ) and the redactio B of Buridan's Questions on De generatione et corruptione (ff. $124^{\mathrm{ra}}-147^{\mathrm{rb}}$ ).

The Questions on Meteorology. The commentary is ascribed to Nicole Oresme in the colophon and in the table of contents that precedes the text ("Expliciunt tabule questionum libri Metheororum a magistro Horem confectarum", f. 1 ${ }^{\mathrm{v}}$; "Et sic est finis Metheororum Horem", f. $53^{\text {rb }}$ ). The text is laid out in two columns of about fifty-five lines each. The handwriting is compact and regular, in brown ink. Corrections (possibly by the copyist himself) above the line and in the margins (e.g. on f. $\mathrm{r}^{\mathrm{r}}, \mathrm{l} .4$ and l. 9). Some marginal notes in another hand refer to the structure of the text and its contents (e.g. on f. 3 ra: "prima"; "oppositum"; "que sit scientia"). The questions are numbered in red by a medieval hand. There is an error in question III.25, Utrum yris solum dupliciter et non multipliciter possit apparere: the number 25 has erroneously been replaced by 21 . The wrong numbering is consistently used until the end of the third book. A modern hand has corrected this numbering by writing the correct number in pencil and putting the incorrect one in parentheses. There are two foliations, both by modern hands: the first one, in grey pencil, in the upper margin of each recto; the second one, in red pencil, in the lower margin. The former is not always present or clearly readable: this might explain why a second foliation was added. The decoration has not been completed: the lines intended for the initial and the incipit of the third book, on $\mathrm{f} .22^{\text {va }}$, have been left blank, just as the space intended for

30 Iacobus de Boxicze is mentioned in the register of students of Krakow University for the year 1456: Album studiosorum Universitatis Cracoviensis, Tomus I (ab Anno 1400 ad Annum 1489), Krakow 1887, 147. He obtained the degree of Master of Arts in 1462 and that of Doctor in Medicine in 1476 (Polski stownik biograficzny, 2, 244-245). Two other manuscripts from the Jagellonian Library belonged to him: ms. 499 (Catalogus, 3, 130-132) and ms. 565 (Catalogus, 4, 7-9).

$31 \quad\langle C\rangle$ irca librum Metheororum queritur primo utrum de impressionibus metheoroloycis sit scientia. Et arguitur quod non, quia huiusmodi impressiones, sicut nubes, tonitrua, non 
the titles of books and questions. The pilcrows are marked with a stroke in red ink. The numbering of the book in the upper margin of each verso leaf is also in red, sometimes using Roman numerals, sometimes the Arabic equivalent.

Incipit and explicit of the books

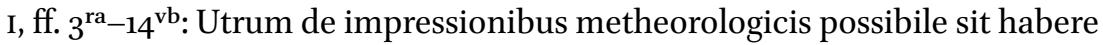
scientiam simul et opinionem. Arguitur quod non, quia de eis non contingit habere scientiam nec opinionem; igitur questio falsa ...X... Ad quartam: 'si galaxia esset de natura celi', etc., concedo, tamen Aristoteles determinat de ea hic propter hoc quia plures antiquorum crediderunt galaxiam esse de natura elementari. Et sic est primi libri finis.

II, ff. $14^{\mathrm{vb}}-22^{\mathrm{rb}}$ : Utrum locus generationis pluvie sit media regio aeris. Arguitur quod non: nullum elementum debet generari extra locum sibi naturalem ...X... Ad rationes in oppositum patet ex secundo articulo. Et sic patet questio. Incipiunt questiones tertii libri Metheororum.

III, ff. $23^{\text {ra }}-47^{\text {va }}$. Utrum ventus sit exalatio calida et sicca. Et arguitur quod non, quia quod non sit exalatio calida ...X... Ad ultimam dico quod non in vanum laborant, ex quo aliam artem ignorant. Et sic est finis questionum tertii libri Metheororum.

IV, ff. $47^{\mathrm{va}}-53^{\mathrm{rb}}$ : Utrum tantum sint quatuor qualitates prime, scilicet caliditas, humiditas, frigiditas et siccitas. Et arguitur primo quod non, quia ...X... Ad sextam dico quod in salamandra non dominatur ignis in quantitate nec etiam nutritur ab igne; sed tale animal non est ustibile ab igne; et ideo, quia non uritur ab igne, dicimus quod tale animal habitet in igne. Et sic est finis Metheororum Horem ad honorem Dei etc.

\section{Bibliography}

Catalogues: Wisłocki, Catalogus, 1: 223; Kowalczyk [et al.], Catalogus, 5: 29630o; Markowski and Włodek, Repertorium, 16o; Lohr, Latin Aristotle Commentaries, I.2. Medieval Authors $M-Z: 40,256 ; 2: 35$.

Literature: Birkenmajer, Études d'histoire des sciences en Pologne, 1: 189-191; Markowski, Burydanizm w Polsce, 403-404; Michael, Johannes Buridan, 2: 639, 687; Streijger, Bakker, and Thijssen (eds.), John Buridan Quaestiones super libros De generatione et corruptione Aristotelis, 16; Panzica, "Albert of Saxony's Questions on Meteorology", 254; Panzica, "Commenter les Météorologiques à l'Université de Cracovie", 82.

sunt perpetue ...X... tunc sunt quatuor conclusiones. Prima est generalis, quod universum et omnia que in eo sunt bene sunt ordinata et post pone illas etc.". On this fragment see A. Panzica, "Albert of Saxony's Questions on Meteorology", 254. 


\section{$9 \quad$ Kraków, Biblioteka Jagiellońska, cod. 2095, ff. $245^{{ }^{r}-307^{r}}\left(\mathrm{Kr}_{2}\right)$}

Paper; mm 210 × 15\%; ff. I+308; 1406

Date and origin. The colophons of the texts contained in this manuscript offer plenty of information about its history. The manuscript was copied at the University of Prague by a Polish student, Iohannes Stolle de Glogovia, in 1406. ${ }^{32}$ Iohannes attended the course on Aristotle's Physics held by Master Lindore of Scotland (f. 221 ${ }^{\mathrm{rb}}$ : "Et sic terminantur questiones totius libri Physicorum Aristotilis summi philosophorum principis, compilate per honorabilem magistrum Laurentium Londoriensem de Scotia, reportate vero per Johannem Stolle de Glogovia Maiori in Studio alme Universitatis Pragensis, anno Domini $\mathrm{M}^{\circ}$ quadragintesimo sexto") and listened to the Questions on Meteorology by Nicole

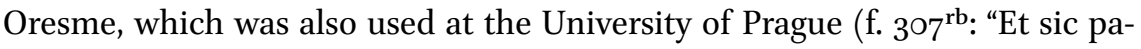
tent questiones totius libri Metheororum compilate per reverendum magistrum Orem Parisiensem et comparate per Johannem Stolle in Studio alme Universitatis Pragensis, a. D. 1406"). The possession marks on the second guard-leaf and on the first leaf confirm the Prague origin of this codex and the fact that it belonged to Iohannes Stolle: "Liber Johannis Stolle de Glogovia, scriptus ab eodem in Studio Pragensi" (this possession mark has been written from right to left by inverting the orientation of each letter); "liber comitatis Maioris Collegii Artistarum. [alia manu] Nicolai a Schadek Prokopiadis liber vetustissimus Pragensis Studii".

Composition. Wooden binding covered with brown pasteboard. Traces of the central boss and of pegs on both covers. The front cover is detached. The first guard-leaf has been torn away. On the second guard-leaf, numbered II by a modern hand, a medieval hand, probably Iohannes Stolle himself, has sketched out a table of contents. ${ }^{33}$ This guard-leaf is followed by 308 leaves grouped mainly in senions according to the following formula: I $(1-12)^{6+6}$; II $(13-24)^{6+6}$;

32 Iohannes Stolle is mentioned as notarius, namely the official reportator, in another manuscript of the Jagellonian Library, ms. 2116, f. Ir: "Super tractatus $\mathrm{P}\langle$ etri $\rangle$ Hyspani datus per notarium, id est Joannem Stolle de Glogovia Maiori" (see Markowski, Repertorium, 115). After having obtained the degree of Master of Arts, he subsequently taught at Krakow and Vienna. On Iohannes Stolle and his collection of philosophical books, see J. Zathey, A. Lewicka-Kamińska, and L. Hajdukiewicz, Historia Biblioteki Jagiellonskiej, 1, 1364-1775, Krakow, 1966, 82-84 and L. Moonan, "The Scientific Writings", 273-317.

33 "In hoc libro continentur primo questiones Phisicorum compilate per magistrum Laurentium Londoriensem de Scotia; secundo problemata collecta de Problematibus Aristotilis; tertio questiones Metheororum Magistri [add. sup. lin.: Nicolai] Orem, quorum librorum autor est Aristotiles, Nycomaci filius, Grecorum sapientissimus, qui scientias invenit et complevit, quia quidquid scripti invenitur ab antiquis scientiis, non est dignum ut sit pars huius scientie vel principium. Nullus eorum qui secuti sunt hunc usque ad hoc tempus, quod est mille et quigentorum annorum, aliquid addidit vel invenit in dictis eius errorem 
III $\left(25^{-36}\right)^{6+6}$; IV $(37-48)^{6+6} ; \mathrm{V}(49-60)^{6+6}$; VI $(61-72)^{6+6}$; VII $\left(73^{-84}\right)^{6+6}$; VIII $\left(85^{-96}\right)^{6+6}$; IX $(97-108)^{6+6}$; x $(109-120)^{6+6}$; XI $(121-132)^{6+6}$; XII $\left(133^{-144}\right)^{6+6}$; XIII $\left(145^{-156}\right)^{6+6}$; XIV $(157-169)^{6+(6+1)}$; XV (170-181 $)^{6+6}$; XVI $(182-193)^{6+6}$; XVII $(194-205)^{6+6}$; XVIII $(206-217)^{6+6}$; XIX $(218-230)^{(6+1)+6}$; XX $\left(23^{1-244}\right)^{7+7}$; XXI $\left(245^{-256}\right)^{5+5}$, f. 255 is a piece of paper bound to the fascicule; XXII $\left(25^{6-}\right.$ $267)^{6+6}$; XXIII $(268-279)^{6+6} ; \operatorname{XXIV}(280-292)^{6+6}$, f. 292 is a piece of paper bound to the fascicule; $\operatorname{XXV}\left(293^{-297}\right)^{4+(4-3)} ; \operatorname{XXVI}(298-308)^{6+(6-1)}$.

Catchwords on ff. $15^{6^{\mathrm{v}}}$ and $169^{\mathrm{v}}$. Signatures: f. $157^{\mathrm{r}}(14) ;$ f. $17 \mathrm{O}^{\mathrm{r}}(15 \mathrm{us}) ;$ f. $182^{\mathrm{r}}$ (16); f. $194^{\mathrm{r}}$ (17us); f. $206^{\mathrm{r}}(18)$; f. $23^{\mathrm{r}}{ }^{ }(2 \mathrm{O})$. A medieval foliation on the right side of the upper margin. The numbering skips one leaf between 107 and 108. This is why, from that point on, a modern foliation accompanies the medieval one: the two foliations are shifted by one unit up to f. 199 (200 according to the modern foliation). The leaf after 199 has been numbered 110 by the medieval hand: the numbering thus continues with 111, 112, 113, and so on. The modern hand numbers these leaves 209, 210, 211, and so on. The leaf that follows 120 has been numbered 200 by the medieval hand. The medieval foliation stops at f. $231(225$ according to the modern numbering).

Content. The manuscript contains Lawrence of Lindores' Questions on Aristotle's Physics (ff. $\mathrm{r}^{\mathrm{ra}}-22 \mathrm{1}^{\mathrm{rb}}$ ); some anonymous questions on matter and form (ff. $\left.221^{\mathrm{va}}-226^{\mathrm{vb}}\right) ; 34$ a set of problemata collected from Aristotle's Problemata (ff. $\left.227^{\mathrm{ra}}-244 \mathrm{bis}{ }^{\mathrm{r}}\right)$, and the second redaction of Oresme's Questions on Meteor$\operatorname{ology}\left(\mathrm{ff} .245^{\mathrm{ra}}-3 \mathrm{O} 7^{\mathrm{rb}}\right)$.

The Questions on Meteorology. The initium and the colophon ascribe the commentary to Nicole Oresme: "Incipiunt questiones Metheororum reverendi magistri Orem, Parisius date ac ab ipso collecte" (f. $245^{\text {ra }}$ ); "Hoc de questione et per consequens de omnibus questionibus librorum Metheororum, compilate per reverendum magistrum Orem Parisiensem et comparate per Johannem Stolle in Studio alme Universitatis Pragensis A.D.1406, pro quarum complectione Dominus noster Iesus Christus" (f. $307^{\mathrm{rb}}$ ). The text is laid out in two columns of about fifty lines each. The handwriting is very readable while being rather rushed. In the margins we find some notes in cursive handwriting, probably by a different hand than that of the copyist (see f. $246^{\mathrm{v}}, 247^{\mathrm{r}}$ ). A modern foliation in blue pencil in the upper outer margin. The initial words of the text

alicuius quantitatis, et talem esse virtutem in uno individuo miraculosum et extraneum existit. Et quia illa dispositio fuit in illo homine, dignus est potius dici divus quam homo". This is drawn from the prologue of Averroes's Commentary on the Physics, ed. Venetiis apud Iunctas, $155^{2-1564, ~ 4: ~ f . ~ 4 v a-5 r a . ~}$

34 "Prima questio: Dubitatur utrum appetitus materie sit ipsa materia naturale vel sit quasi distinctum ab ipsa materia. Et videtur primo quod sit res distincta ab ipsa materia. Secunda questio: Queritur hic utrum forme rerum naturalium sunt distincte a rebus naturalibus". 
("Incipiunt questiones Metheororum reverendi magistri Orem"), in textualis, are placed so as to form a square with a height of about eighteen lines. Pointing hands (see f. $246^{\mathrm{rb}}$ ), rubrics and pilcrows in red. The words that refer to the structure of the text are sometimes underlined in red (see f. $245^{\mathrm{v}}$ ). Questions I.1O and III.16 are copied on separate leaves of reduced size that were then bound to the manuscript and included in the foliation. On the verso of one of them, the copyist has drawn a polygon around whose perimeter he has written: "hic nichil desinit nisi aurum et argentum, oves et boves et alia multa quorum non est numerus" (f. $292^{\mathrm{v}}$ ). On f. $297^{\mathrm{r}}$, after question III.19, we find a table of contents corresponding to the questions on Physics, which continues until the following verso leaf. Many leaves have been torn out, and the remaining questions of the third book (III.2O-35) are missing. The fourth book begins at f. $298^{\mathrm{r}}$.

Incipit and explicit of the books

I, ff. $245^{\text {ra }}-265^{\text {ra }}$ : Incipiunt questiones Metheororum reverendi magistri Orem, Parisius date ac ab ipso collecte, quarum prima est: utrum possibile sit de impressionibus metheorologicis habere scientiam et opinionem. Arguitur quod non, quia de eis non contingit habere scientiam nec opinionem, ergo questio falsa ...X... propter hoc quod plures antiquorum crediderunt galaxiam esse de natura elementari.

II, ff. $265^{\text {ra }}-276^{\text {vb: }}$ Circa secundum librum Metheororum: utrum $\langle$ locus $\rangle$ generationis pluvie sit media regio aeris. Arguitur quod non, quia nullum elementum debet generari extra locum sibi naturalem ...X... Ad rationes in oppositum patet ex secundo articulo.

III, ff. $27^{\text {vb }}-297^{\text {ra: }}$ Circa tertium: utrum ventus sit exalatio calida et sicca. Et arguitur quod non sit exalatio calida, quia, si sic, sequeretur ...X... in hoc seculo nichil scimus. Hoc de questione.

IV, ff. $289^{\text {ra }}-307^{\text {rb}}$ : Queritur circa principium ipsius quarti primo utrum tantum sint quatuor qualitates prime, scilicet caliditas, humiditas, frigiditas et siccitas. Et arguitur primo quod non, quia ...X... sed tale animal non est ustibile ab igne, nec etiam nutritur ab igne. Ratio huius, quia non uritur ab igne, dicimus quod tale animal habitat in igne. Hoc de questione et per consequens de omnibus questionibus librorum Metheororum, compilate per reverendum magistrum Orem Parisiensem et comparate per Johannem Stolle in Studio alme Universitatis Pragensis a. D. 1406.

Bibliography

Catalogues: Wisłocki, Catalogus, 2: 507; Markowski and Włodek, Repertorium, 109; Lohr, Latin Aristotle Commentaries, I.2. Medieval Authors M-Z: 365-366, 2: 35 .

Literature: Birkenmajer, Études d'histoire des sciences en Pologne, 183-186; Markowski, Burydanizm w Polsce, 404-405; McCluskey, Nicole Oresme on Light, 
Color and the Rainbow, 86; L. Moonan, "The Scientific Writings of Lawrence of Lindores (d. 1437)", Classica et Mediaevalia 39 (1988), 273-317, at 278-283; Panzica, "Commenter les Météorologiques à l' Université de Cracovie", 83.

10

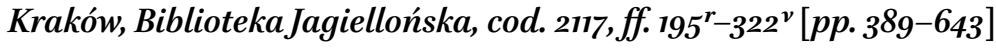
$\left(\mathrm{Kr}_{3}\right)$

Paper; $\mathrm{mm} 215 \times 155$; I+326; 1444-1450

Date and origin. This manuscript consists of two parts. The first one (ff. 1-74) was copied in 1444 in Głogów (Lower Silesia), as emerges from the colophon on $\mathrm{f} .74^{\text {ra: }}$ "Finitus 6 feria sub sermone ante festum Michaelis per Vincentium Kenczel in Glogouia Maiori, sub anno Domini 1444". The second part (ff. 75322) was copied in 145 o by Paulus de Zorawia, a student in Frankfurt (Oder), as proved by the colophon on f. $3^{22^{\mathrm{v}}}$ : "Et finito libro post festum Pasce, quarta feria in die Viti anno Domini 1450 per Paulum de Zorawia imbuens scientys gymnasy Frankenfordensis".

Composition. A parchment guard-leaf, followed by 326 paper leaves grouped in senions: I $(1-14)^{6+6} ; 3^{65}$ II $\left(15^{-26}\right)^{6+6}$; III $(27-38)^{6+6}$; IV $(39-50)^{6+6}$; V $\left(5^{-}\right.$ $62)^{6+6}$; VI $\left(63^{-74}\right)^{6+6}$; VII $\left(75^{-86}\right)^{6+6}$; VIII $(87-98)^{6+6}$; IX $(99-110)^{6+6}$; $\mathrm{x}(111-$ $122)^{6+6}$; XI $\left(123^{-134}\right)^{6+6}$; XII $\left(135^{-146}\right)^{6+6}$; XIII $\left(147^{-158}\right)^{6+6}$; XIV $\left(159^{-170}\right)^{6+6}$; XV $(171-182)^{6+6}$; XVI $\left(183^{-194}\right)^{6+6}$; XVII $\left(195^{-206}\right)^{6+6}$; XVIII $(207-218)^{6+6}$; XIX $(219-$ $230)^{6+6}$; XX $\left(23^{-242}\right)^{6+6}$; XXI $\left(243^{-254}\right)^{6+6}$; XXII $\left(255^{-266}\right)^{6+6}$; XXIII $\left(267^{-}\right.$ $278)^{6+6} ; \operatorname{XXIV}(279-290)^{6+6} ; \operatorname{XXV}(291-302)^{6+6} ; \operatorname{XXVI}\left(303^{-315}\right)^{6+6} ; 36 \operatorname{XXVII}(316-$ $\left.3^{26}\right)^{6+6}$, the last leaf has been torn out. In the outer margin, we find a pagination in black ink and a foliation in grey pencil, both by modern hands.

Content. This manuscript contains some texts on natural philosophy: a commentary on Peter of Dresden's Compendium of natural philosophy $\left(\mathrm{ff}^{\mathrm{r}} \mathrm{r}^{\mathrm{r}}-74^{\mathrm{v}}\right) ;{ }^{37}$ Marsilius of Inghen's Questions on the Parva naturalia (ff. $75^{\mathrm{r}}-194^{\mathrm{v}}$ ); Nicole Oresme's Questions on Meteorology (ff. $195^{\mathrm{r}}-322^{\mathrm{v}}$ ). These texts are followed by the corresponding table of contents: that of Oresme's commentary on ff. $325^{\mathrm{r}}-$ $33^{\mathrm{v}}$, and that of Marsilius's Questions on $\mathrm{ff} .323^{\mathrm{r}}-324^{\mathrm{v}}$.

The Questions on Meteorology. The colophon ascribes the commentary to Guillaume Oresme: "Et sic est finis Metheororum reverendi magistri Wilhelmi de Orem", f. $32^{2}$. The text has been assembled from two copies by different copyists. The first part (ff. 195-206) stops in the middle of question I.7. The page

Ff. 4-5 are pieces of paper bound to the manuscript.

$36 \quad$ Folio 304 is a piece of paper bound to the manuscript.

37 Inc.: “'omnis gloria eius filie regis ab intus in fimbriis aureis' [Ps. 44, 14]. Hec verba,

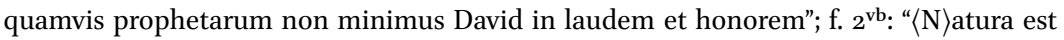
principium. Iste libellus introductorius in philosophiam naturalem principali sui divi- 
layout of the two parts is different. In the first part, the text is displayed in two columns of about fifty lines each. The words that refer to the internal structure of the questions are in textualis. The second part (ff. 207-322), copied by Paulus de Zorawia, is written longis lineis. The space intended for the internal divisions of the questions has remained blank. A modern hand has numbered the questions in grey pencil, restarting the numbering at the beginning of each book. Signatures in the upper margin, between the two columns (ai, aii, aiii ...).

The last question of the third book ends on the recto of a piece of leaf that has been bound to the manuscript, as in the case of ms. 2095. The fourth book begins on the verso of the same leaf, which is numbered 304. The decoration has not been completed. On f. $195^{\mathrm{r}}$, the first words of the text (" $\langle\mathrm{C}\rangle$ irca materiam Orem super Metheorum queritur primo utrum") are written in textualis and placed so as to form a square with a width of nineteen lines; the space intended for the initial " $C$ " has also been left blank. The pilcrows start on f. $195^{\text {va }}$ and stop shortly thereafter on f. $196^{\mathrm{rb}}$. On ff. $195^{\mathrm{v}}-196^{\mathrm{r}}$, the words that refer to the structure of the questions are written in large characters and surrounded by a red frame. We do not find any rubrics in the rest of the text.

The manuscript was misbound before it was foliated. On the bottom margin of f. $218^{\mathrm{v}}$, a medieval hand wrote "quere in quarto sexternio" and a modern hand added: "= 509". This anomaly is also indicated by a pointing hand on f. $218^{\mathrm{v}}$, next to which we find a small $a$. The pointing hand, just like the $a$, reappears on f. $255^{\mathrm{r}}$. The text stops again at f. $266^{\mathrm{v}}$ : another pointing hand tied with a thin string to the letter $a$ shows up, this time without any reference to a specific folio. In the upper margin of f. $243^{\mathrm{r}}$, we find another pointing hand next to the letter $b$. The text then proceeds until f. $254^{\mathrm{v}}$, where another interruption occurs, and we find another letter $b$ in the upper margin. In the upper margin of f. $219^{\mathrm{r}}$, we find the letter $c$; in the upper margin of f. $242^{v}$, the letter $d$, and in the upper margin of f. $267^{\mathrm{r}}$ the letter $e$. The correct order of the folios would thus be: ff. 195-218; $255^{-266 ; 243-254 ; 219-242 ; 267-322 .}$

Incipit and explicit of the books

I, f. $195^{\text {ra }}-257^{\mathrm{v}}$ : $\langle\mathrm{C}\rangle$ irca materiam Orem super Metheorum [sic] queritur primo utrum possibile sit de impressionibus metroloycis [sic] simul habere scientiam et opinionem. Et arguitur quod non, quia de impressionibus metroloycis $[$ sic $]$ non contingit habere scientiam nec opinionem; ergo etc. ...X... Ad quartam: 'si galaxia esset de natura celi, tunc de ea non esset determinandum in isto libro', concedo. Et cum dicitur: 'tamen Aristoteles determinavit de ea hic',

sione dividitur in tres tractatus"; expl.: "in hac vita in suis effectibus, sed perfecte cognosci etiam in vita eterna, que donare dignetur Iesus Christus benedictus in secula seculorum. Amen". 
respondetur quod hoc fecit propter hoc quod plures antiquorum crediderunt quod galaxia est de natura elementari, et propter eorum opinionem ipse talem materiam hic tetigit. Et sic est finis questionum primi libri Metheororum.

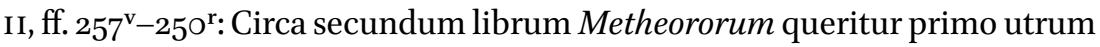
locus generationis pluvie sit media regio aeris. Et arguitur quod non: nullum elementum debet generari extra locum sibi naturalem ...X... Ad rationes in oppositum patet ex secundo articulo. Et sic est finis secundi libri $M e$...

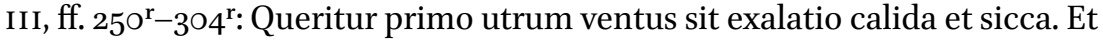
arguitur primo quod non sit exalatio calida, nam sic sequeretur quod in temporibus ventosis ...X... Ad ultimam dico quod in vanum laborant [sic], ex quo aliam artem ignorant. Sequitur quartus.

IV, ff. $304^{\mathrm{v}}-322^{\mathrm{v}}$ : Circa initium quarti libri Metheororum queritur primo utrum tantum quatuor sunt qualitates prime, scilicet caliditas, humiditas, siccitas et frigiditas. Et arguitur primo quod non, quia quod per superhabundantiam dicitur, uni soli rei convenit ...X... Ad sextam dico quod in salamandra non dominatur ignis in quantitate $\langle$ nec $\rangle$ etiam nutritur ab igne; sed tale animal non est ustibile ab igne; et ideo, quia non uritur ab igne, dicimus quod ipsum habitat in igne. Et sic est finis Metheororum reverendi magistri Wilhelmi de Orem, pro quo sit benedictus Deus in secula seculorum. Et finito libro post festum Pasce, quarta feria in die Viti anno Domini 145 o per Paulum de Zorawia imbuens sciencys gymnasy Frankenfordensis.

\section{Bibliography}

Catalogues: Wisłocki, Catalogus, 2: 511; Markowski and Włodek, Repertorium, 115-116; Lohr, Latin Aristotle Commentaries, I.2. Medieval Authors M-Z: 35.

Literature: Birkenmajer, Études d'histoire des sciences en Pologne, 186-189; Markowski, Burydanizm w Polsce, 405; McCluskey, Nicole Oresme on Light, Color and the Rainbow, 86-87; Panzica, "Commenter les Météorologiques à l'Université de Cracovie", 83 .

11

Leipzig, Universitätsbibliothek, ms. $1387, f f .181^{r_{-}}{ }^{27}{ }^{r}(\mathrm{~L})$

Paper; mm 300 × 210; ff. I+276+I; 1429-1438

Date and origin. The first two texts contained in this manuscript, Marsilius of Inghen's Questions on Metaphysics and Questions on De generatione et corruptione, were copied in Frankfurt (Oder) by Iacobus Thysenaw of Prettin (see below, codicology). ${ }^{38}$ The colophon of the second text informs us of the date

38 G. Erler, Die Matrikel der Universität Leipzig 1409-1599, 1 (Leipzig 1985):116; 2 (Leipzig 1987): 120,125 . 
when the copy was made: "Et sic est finis huius libri De generatione et corruptione venerandi magistri Marsilii anno Domini $\mathrm{m}^{\circ} \operatorname{cccc} \mathrm{xxxvii}$, quarta feria ante festum Viti, reportatum per quemdam Iacobum de Prettin et ab eodem pronuntiatum" (f. $176^{\mathrm{vb}}$ ). The third text transmitted in this manuscript, Nicole Oresme's Questions on Meteorology, was copied in Leipzig in 1429, as stated by the colophon on f. $274^{\text {rb: }}$ "Expliciunt questiones magistri Orem super libros Metheororum scripte in studio Lipzii et finite anno domini millesimo quadragintesimo vicesimo nono". Ff. $275^{\mathrm{r}}-276^{\mathrm{v}}$ contain some texts related to the Council of Basel of the years 1437-1438 and that were written in Frankfurt and Leipzig. The manuscript is mentioned in the catalogue of the Leipzig Faculty of Philosophy of 1480 under the signature " $\mathrm{H}$ inferior n. 150 " and in a catalogue of the same library compiled around 156o under the signature 209.

Codicology. Wooden binding. Traces of pegs and of the central boss. On the inside front cover, we find a paper guard-leaf with a medieval inscription: "Questiones Marsilii de Inghen super Methaphysicam et super De generatione et corruptione. Item questiones Wilhelmi Orem super Metheororum". On a parchment guard-leaf we read: "Liber magistri Jacobi Thysenaw de Prettin, quem ipse propriis manibus conscripserat et ipsum estimat in valore vi f. renensium in auro. Metaphisicam ipse exemplar collegit Frankfenfordis ibidem pro tunc locatus existens. Marsilium Lipczk pronunciavit et pronunciando sic conscripsit Orem super Metheororum, intendita pro pecunia comparavit. [alia manu]: super De generatione et corruptione". This guard-leaf is followed by 275 paper leaves: I $(2-13)^{6+6}$; II $(14-25)^{6+6}$; III $(26-37)^{6+6}$; IV $(38-49)^{6+6}$; V $\left(5^{\circ}-61\right)^{6+6}$; VI $(62-73)^{6+6}$; VII $(74-85)^{6+6}$; VI $(86-98)^{6+6}$; IX (99-100) two cut folios + 2; X $(101-112)^{6+6}$; XI $\left(113^{-124}\right)^{6+6}$; XII $\left(125^{-133}\right)^{5+5-1}$; XIII $(134-144)^{6+6}$; XIV $\left(145^{-156}\right)^{6+6}$; XV $\left(157^{-168}\right)^{6+6}$; XVI $(169-180)^{6+6}$; XVII $(181-192)^{6+6}$; XVIII $\left(193^{-204}\right)^{6+6}$; XIX $\left(205^{-216}\right)^{6+6}$; XX $\left(217^{-228}\right)^{6+6}$; XXI $(229-240)^{6+6}$; XXII $(241-$ $\left.25^{2}\right)^{6+6}$; XXIII $\left(253^{-264}\right)^{6+6}$; XXIV $\left(265^{-276}\right)^{6+6}$. At the end of the volume, we find a parchment guard-leaf numbered 277 by a modern hand. Signatures on the recto leaves: f. 38 (traces of a crossed out signature); f. 74 (7); f. 86 (8? cut off); signature 9 on the remains of a cut off leaf after f. 98; f. 113 (10); f. 125 (11); f. 134 (12? cut); f. 145 (13); f. 157 (14); f. 169 (15).

The manuscript has two foliations: a medieval one in brown ink, in the upper margin between the two columns, and a modern one in pencil, in the outer margin. The medieval foliation begins with the second leaf of the first text, the Questions on Metaphysics, numbered 2, while the modern foliation assigns this number to the preceding leaf. This discrepancy of one unit between the two foliations continues up until f. 89 ( 88 according to the medieval foliation). Leaf 42 is numbered 43 by the medieval hand, but this mistake has no effect on the overall numbering, as the following leaf is also numbered 43. Starting with f. 89, 
the difference between the medieval and the modern numbering increases to two units due to the modern one jumping from 89 to 91 . Another error occurs in the modern numbering, which numbers the leaf between 141 and 142 as 141a, thus reducing again the gap between the two numberings. Leaves 168169 (169-170 according to the modern numbering) have not been numbered by the medieval hand, which however resumes the numbering correctly with f. 170 (171 according to the modern numbering). In the same way, leaves $178-$ 179 (179-180 according to the modern numbering), which are blank, have not been numbered by the medieval hand, which restarts with $\mathrm{f}$. 180 (181 according to the modern numbering).

Content. This manuscript contains Marsilius of Inghen's Questions on the Metaphysics (ff. $2^{\mathrm{ra}}-112^{\mathrm{rb}}$ : books I-II, IV-X, XII), ${ }^{39}$ followed by a corresponding table of contents (ff. $112^{\mathrm{rb}-\mathrm{vb}}$ ); Marsilius of Inghen's Questions on De generatione et corruptione ( $\left.\mathrm{ff} .113^{\mathrm{ra}}-176^{\mathrm{vb}}\right) ; 4^{40}$ an anonymous question about universals (ff. $\left.177^{\mathrm{va}}-178^{\mathrm{ra}}\right) ;^{41}$ the second redaction of Oresme's Questions on Meteorology (ff. $181^{\text {ra }}-274^{\text {rb }}$ ), followed by the corresponding table of contents (ff. $274^{\text {va }}$ $275^{\mathrm{ra}}$ ), and some juridical texts concerning the University of Leipzig. ${ }^{42}$

The Questions on Meteorology. The colophon ascribes the commentary to Oresme (though without mentioning his first name), while the references on the front and on the back plates ascribe it to Guillaume Oresme. The text is copied in two columns of about forty lines each. The handwriting is widely spaced and easy to read; the ink is brown. We find two foliations: the first, a medieval one, in the central upper margin; the second, a modern one, in the

39 Inc.: "Circa initium Methaphysice. Utrum methaphysica sit sapientia. Et arguitur primo quod non, quia sapientia est scientia principalium; sed methaphysica non est huiusmodi"; expl.: "auctoritates post oppositum sunt pro dictis in tertio articulo. Hic est finis Methaphysice".

$40 \quad$ Inc.: "Circa librum De generatione et corruptione queritur utrum ens mobile ad formam sit subiectum scientie libri De generatione et corruptione"; expl.: "ratio post oppositum est pro ultima conclusione de questione ultima huius libri secundi, et consequenter de omnibus. Et sic est finis huius libri De generatione et corruptione venerandi magistri Marsilii. Anno domini $\mathrm{m}^{\circ}$ cccc xxxvii, quarta feria ante festum Viti. Reportatum per quemdam Iacobum De Prettin et ab eodem pronuntiatum. Sit laus Deo". On f. $140^{\mathrm{rb}}$, we find a table of contents for the first book; at the end of the text, on f. $177^{\text {ra }}$, there is a table of contents for the second book.

41 Inc.: "Utrum universale reale in essendo secundum viam Platonis et Socratis sit ponendum. Et probatur multipliciter sic. Primo: illa est concedenda: 'bonum est"'; expl:: "omnibus singularibus non distinctum ab eis".

42 "Copia littere dominorum electorum" (colophon: "Datus Frankfordie die xvii, mensis Marcy, Anno domini Mo cccc xxxviii", f. 275 $)$ ); "Copia bulle lecte in sessione generali" (f. $27^{\mathrm{r}}$ ); "Responsium domini Eugenii super scripta Universitatis studii Lipzii" (f. $276^{\mathrm{r}}$ ); "Missiva nuncii horum" (f. $276^{\mathrm{r}}$ ). 
outer upper margin. Marginal notes by the copyist refer to the content of the text. At the beginning of the books, we find large initials. In the first and second books, the initials are bichrome, red and blue. The incipit of the fourth book is written in the shape of a square around a big initial $C$ in red. Rubrics and pilcrows in red. Some structuring words are sometimes surrounded by a squared box in red (as for example on f. $181^{\mathrm{vb}}$ ). The first words of the questions, in textualis, are also squared in red.

An error in the numbering of the questions occurs at the end of the third book. The question that in other manuscripts is numbered III.33 (Utrum, visa yride et Sole vel astro elevato notabiliter super horizontem, apparet minor portio maioris circuli quam appareat Sole existente in fine horizontis) is referenced as III.34, without III.33 appearing anywhere else. Consequently, the subsequent questions, which in the other manuscripts are numbered III.34 and III.35, are numbered III.35 and III.36. Another error occurs at the end of the fourth book. The question that is numbered IV.7 in the other manuscripts (Utrum balnea conferant ad digestionem), is numbered IV.6 here, just like the previous one. As a result, question IV.8 (Utrum sint tantum tres digestiones) becomes question IV.7. This discrepancy continues until the end of the fourth book. It is important to notice that this difference in the Leipzig manuscript does not affect the questions themselves, but only their numbering, as no question has been added or removed.

Incipit and explicit of the books

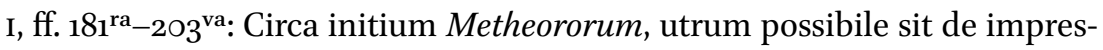
sionibus meteorologicis habere scientiam simul et opinionem. Et arguitur primo quod non, quia de impressionibus metroloycis non contingit habere scientiam nec opinionem, ergo questio falsa ...X... Ad quartam: 'si galaxia esset de natura celi, tunc de ea non esset determinandum in isto libro', concedo. Et cum dicitur: 'tamen Aristoteles determinavit de ea hic', respondetur quod fecit propter hoc quia plures antiquorum crediderunt galaxiam esse de natura elementari, et propter eorum opinionem ipse talem materiam hic tetigit. Et sic est finis libri primi. Explicit liber primus Metheororum.

II, ff. $203^{\text {vb }}-216^{\text {vb }}$ : Circa initium libri secundi Metheororum primo queritur utrum locus generationis pluvie sit media regio aeris. Et arguitur primo quod non: nullum elementum debet generari extra locum sibi naturalem ...X... Rationes patent in secundo articulo huius questionis. Et tantum de ista questione, et per consequens de toto libro secundo huius Metheororum.

III, ff. $216^{\mathrm{vb}}-261^{\mathrm{rb}}$ : Liber tertius Metheororum. Circa initium tertii libri $\mathrm{Me}$ theororum primo queritur utrum ventus sit exalatio calida et sicca. Et arguitur quod non sit exalatio calida ...X... Ad ultimum: quod non in vanum laborant, ex quo aliam artem ignorant, etc. [rubr:: Sequitur liber quartus, etc. Ave Gertrudis 
virgo grata ex regali stirpe nata leprosos mundare non sprevisti ob amorem Iesu Christi, cecis viam demonstrasti, etc. Sponsa mea].

IV, ff. $261^{\mathrm{va}}-274^{\mathrm{rb}}$ : Circa primum quarti Metheororum primo movetur ista questio, utrum tantum sint quatuor qualitates prime, scilicet caliditas, humiditas, frigiditas et siccitas. Et arguitur quod non, quia quod per superhabundantiam dicitur, uni soli convenit ...X... Ad ultimam dico quod in salamandra non dominatur ignis in quantitate, sed tale animal non est ustibile $a b$ igne nec uritur ab igne; et ideo, quia non uritur ab igne, dicimus quod tale animal habitat in igne, etc. Expliciunt questiones magistri Orem super libros Metheororum, scripte in Studio Lipczensi et finite anno domini millesimo quadragintesimo vicesimo nono.

\section{Bibliography}

Catalogues: L.J. Feller, Catalogus codicum manuscriptorum Bibliothecae Paulinae in Academia Lipsiensi, Lipsiae 1686, 362, nr. 71 [in this catalogue the Questions on Meteorology are attributed to Guillaume Oresme, as in the colophon of the manuscript]; Lohr, Latin Aristotle Commentaries, I.2. Medieval Authors M-Z: 35; M. Markowski, Repertorium commentariorum medii aevi in Aristotelem Latinorum, qui in Bibliotheca Universitatis Lipsiensis asservantur, Krakow 2012, 76 and 234 .

Literature: Birkenmajer, Études d'histoire des sciences en Pologne, 191-192; D. Döring, Die Bestandsentwicklung der Bibliothek der Philosophischen Fakultät der Universität zu Leipzig von ihren Anfängen bis zur Mitte des 16. Jahrhunderts: ein Beitrag zur Wissenschaftsgeschichte der Leipziger Universität in ihrer vorreformatorischen Zeit, Leipzig 1990 (Beiheft 99 zum Zentralblatt für Bibliothekswesen), 6o, 70; H.-U.Wöhler, "Die erste philosophische Fakultät in Sachsen bis zum Beginn der Reformation in localen, regionalen und überregionalen Kontext", Bochumer Philosophisches Jahrbuch für Antike und Mittelalter 13 (2008), 217-240.

12

München, Bayerische Staatsbibliothek, Clm 4376, ff. $r^{r}-64^{r}(\mathrm{M})$

Paper; mm 285×215; ff. II + 152; 1365-1386

Date and origin. The texts contained in this manuscript were copied at Prague University between 1365 and 1386, as emerges from the initia and the colophons: "Expliciunt questiones primi [corr. sup. lin. ex secundi] libri Metheororum, finite die beati Erhardi martiris atque pontificis, anno Domini ${ }_{1366}$ " (f. $15^{\mathrm{vb}}$ ); "expliciunt questiones quatuor librorum Metheororum Byridani, finite Prage anno Domini $13^{\circ} 66$ to, in vigilia beate Dorothee virginis, per pedes Johannis Krichpaumi de Ingol/stat)" (f. $64^{\text {rb}) ; ~ " i n c i p i t ~ d e c l a r a t i o ~ m a g i s t r o r u m ~ s a n c t e ~}$ theologie sancte Universitatis studii Pragensis [...], anno Domini 1386" (f. 66 ${ }^{\text {va }}$ ); 
"expliciunt questiones super totalem librum De senso et sensato collecte Parysius per reverendum magistrum Albertum de Rychmersdorf, pronunciate Prage in quadam bursa tunc temporis, anno MCCCLXV, feria quarta proxima post assumptionem virginis gloriose per Johannem Krichpaumum de Ingolstat, finite in die Sancti Bernhardi" (f. 86 $6^{\mathrm{rb}}$ ); "expliciunt questiones De sompno et vigilia, anno Domini $1367 \mathrm{mo}^{\circ}$ (f. $100^{\mathrm{vb}}$ ); "hic sit finis questionum De longitudine et vite brevitate in Praga anno Domini millesimo $\mathrm{CCC}^{\circ} \mathrm{LXVII}$, in vigilia gloriosissime annunciationis virginis Marie per Johannem Krichpaumum de Ingol/stat)" (f. 104 ${ }^{\mathrm{va}}$ ); "et sic patent questiones primi De anima finite sabato ante festum palmarum in Praga, anno Domini 1365to" (f. $107^{\mathrm{va}}$ ).

Most of the texts have been copied by Iohannes Krichpaum from Ingolstadt, a student at the Prague Arts Faculty who identifies himself in the colophons (see f. $64^{\text {rb }}$, f. $86^{\mathrm{rb}}$ and f. $107^{\mathrm{va}}$ ). Similarly to the $\mathrm{ms}$. Clm 4375 of the Bavarian State Library, which transmits a copy of the first redaction of Oresme's Questions on Meteorology, this manuscript came into the possession of the abbey of SS. Ulrich and Afra in Augsburg. In the upper margin of f. $1^{\mathrm{r}}$, we read: "Monasterii S. Udalrici Aug".

Composition. Wooden binding; traces of clasps on the front cover. On the lower part of the front cover, we find a votive image of the abbey of SS. Ulrich and Afra in Augsburg, which is accompanied by the words: "P.P. Benedictinorum, Lib. et Imp. Monasterii S.S. Udalrici et Affrae Augustae". Two parchment guard-leaves. On the first one, a medieval hand wrote: "Buridani". These leaves are followed by $15^{2}$ paper leaves, grouped mainly in quinions: $\mathrm{I}(1-10)^{(6-1)+5}$; II $(11-20)^{5+5}$; III $(21-30)^{5+5}$; IV $(31-41)^{6+(6-1)}$; V $(42-51)^{5+5}$; VI $\left(5^{2-61}\right)^{5+5}$; VII $(62-$ $67 \mathrm{~d})^{5+5}$; VIII $(68-77)^{5+5}$; IX $(78-87)^{5+5}$; x (88-97 $)^{5+5}$; XI (98-104c $)^{5+5}$; XII $\left(105^{-}\right.$ $114)^{5+5}$; XIII $\left(115^{-124}\right)^{5+5}$; XIV $\left(125^{-134}\right)^{5+5}$; XV $\left(134^{-144}\right)^{5+5}$; XVI $\left(145^{-15^{2}}\right)^{4+4}$.

Signatures in the first leaf of each fascicule (from $a$ to $q$ ). The first fascicule begins with the signature "a ii", as the first leaf has been ripped.

Two modern foliations in the upper margin: the first one in black ink; the second one in pencil. Since the leaves that should have been numbered 68, 69, 70 and 71 are blank, they have been omitted from the numbering by the blackink hand. The pencil hand has numbered them $67 \mathrm{a}, 67 \mathrm{~b}, 67 \mathrm{c}$, and $67 \mathrm{~d}$. The same circumstances apply to ff. 105, 106 and 107, which are numbered in pencil 104a, 104b, and 104c. Ff. 17-19, 26-29, 31, 33-34, 36-39, 42, 47, 48-53, 57-59, 61-63, 6869, 71-74, 76, 77, 78, 79, 81, 82, 83, 84, 127, 128, 129, 131, 132, 133, 134, 136, 137, 138, $139,143,144,146,147,148,149,15^{2}$ have not been numbered.

Content. The academic origin of this manuscript is reflected in its content, which consists mostly of commentaries on Aristotle's natural philosophy by Parisian masters of the second half of the fourteenth century: the second redaction of Oresme's Questions on Meteorology (ff. $\left.1^{\mathrm{ra}}-64^{\mathrm{rb}}\right)$; an anonymous ques- 
tion about the plague (ff. $\left.64^{\mathrm{va}}-66^{\mathrm{rb}}\right) ;{ }^{43}$ a declaration of the masters of Prague University (ff. $\left.66^{\mathrm{va}}-67^{\mathrm{vb}}\right) ;{ }^{44}$ the Questions on De sensu et sensato ascribed to Albert to Saxony or Nicole Oresme (ff. $\left.68^{\mathrm{ra}}-86^{\mathrm{rb}}\right) ;^{45}$ some questions on $D e$ memoria et reminiscentia (ff. $\left.86^{\mathrm{va}}-9^{\mathrm{ra}}\right)$ and on De somno et vigilia $\left(91^{\mathrm{ra}}-100^{\mathrm{vb}}\right)$, which should probably be ascribed to Albert of Saxony; two anonymous questions on De somno et vigilia $\left(100^{\mathrm{vb}}-101^{\mathrm{vb}}\right) ; 4^{46}$ a set of questions on De longitudine et brevitate vite (ff. $102^{\mathrm{va}}-104^{\mathrm{va}}$ ), which should also probably be ascribed to Albert of Saxony; the second redaction of Buridan's Questions on De anima (ff. $105^{\mathrm{ra}}-124^{\mathrm{vb}}$; ff. $\left.150^{\mathrm{va}}-15^{\mathrm{va}}\right) ;{ }^{47}$ the redactio $B$ of Buridan's Questions on De generatione et corruptione (ff. $125^{\mathrm{ra}}-15^{\mathrm{O}}{ }^{\mathrm{rb}}$ ).

The Questions on Meteorology. The colophon ascribes the commentary to Buridan: "Expliciunt questiones quatuor librorum Metheororum Byridani" $\left(\right.$ f. $\left.64^{\text {rb }}\right)$. The text is copied in two columns of about fifty lines each. The handwriting is regular; the ink is brown. Annotations in the margin by the copyist. The incipits of the books, just like the first words of each question, are copied in textualis and have a rubricated initial. The numbering of the questions is inconsistent. A first mistake occurs after question III.11 (Utrum typho et ecnephya et incensio sint exalationes calide et sicce), correctly introduced by the words "undecimo queritur". The subsequent question (Utrum visus refrangatur

43 Inc.: "Quia secundum Aristotelem in prohemio Metaphysice: 'propter admirationem antiqui inceperunt phylosophari', et quia omnes miramur de pestilentia [...], ergo circa libellum Secretorum Aristotelis queritur ista questio: utrum morbus pestilentie effective proveniat ab influentia corporum supercelestium"; expl.: "ad ultimam oportet si Saturnus et Mars etc., sed parvam et transitoriam; ergo non est efficax ad ista inferiora".

44 Inc.: "Incipit declaratio magistrorum facultatis theologie sancte Universitatis studii Pragensis".

45 The text is attributed to Albert in the colophon of this manuscript ("Expliciunt questiones super totalem librum De sensu et sensato collecte Parisius per reverendum magistrum Albertum de Richmersdorf, pronunciate Prage in quadam bursa tunc temporis anno MCCCLXv per Johannem Krichpaumum de Ingolstat finite in die sancti Bernardi") and to Oresme in manuscript Erfurt, Universitäts- und Forschungsbibliothek, Dep. Erf. $4^{\circ}$ 299 (f. 128: "Questiones Parvorum naturalium Orem"). This commentary was edited by J. Agrimi, Le Questiones de sensu attribuite a Oresme e Alberto di Sassonia, Florence 1983 (Pubblicazioni della Facoltà di lettere e filosofia dell'Università di Pavia, 29), who did not manage to solve the problem of its attribution (see particularly 9-33 of the introduction).

46 Inc.: "Queritur utrum sompnus sit causa sanitatis. Arguitur quod non, quia si sic, sequitur quod vigilia est”; expl: "nec etiam generatur disproportio humorum nec qualitatum. Et sic patet questio". II. Inc.: "Queritur utrum oculus mulieris menstruose inficiat speculum. Et videtur quod non: omne agens est simile cum passo"; expl.: "quod eodem modo mulier menstruosa ..." [incomplete].

47 In his inventory of medieval commentaries on Aristotle in the Bavarian State Library, Markowski fails to notice that this text does not end at f. $124^{\mathrm{vb}}$, but continues on $\mathrm{f} .15 \mathrm{O}^{\mathrm{va}}$. 
in occursu medii densioris et rarioris), which is the twelfth of the third book, is, however, introduced by the words "tredecimo queritur". This mistake persists until the question Utrum yris sit forma dyaphanalis vel specularis, vel utrum fiat per reflexionem vel per refractionem, which in this manuscript is numbered III.23 and in the others III.22. The following question (Utrum, supposito quod yris fiat per reflexionem radiorum, utrum tunc fiat in nube vel super guttulas roridas vel super stillicidia), at $\mathrm{f} .43^{\mathrm{vb}}$, is preceded by the words "queritur vicesimo secundo", even if it is numbered III.24 (III.23 in the other manuscripts). As a result, the following two questions (Utrum omnes yris debeat esse tricolor and Utrum yris solum dupliciter et non multipliciter potest apparere) are numbered III.23 and III.24. Surprisingly, the subsequent question (Utrum semper, apparentibus duabus yridibus, superior yris debet habere colores conversim positos) is introduced by the words "queritur vicesimo octavo". This new numbering continues until the question Utrum, visa yride et Sole vel astro elevato notabiliter super horizontem, apparet minor portio maioris circuli quam appareat Sole existente in fine horizontis (f. $5^{2 \mathrm{a}}$ ), which is numbered III.35 in our codex and III.33 in the other manuscripts. At that point, the copyist, who probably became aware of the mistake, numbered the following questions III.34 and III.35 (and not III.36 and III.37, as he should have done on the basis of his erroneous numbering) in agreement with the numbering of the other manuscripts.

Incipit and explicit of the books

I, ff. $1^{\text {ra }}-15^{\text {vb: }}$ Primo queritur circa initium primi libri Metheororum utrum possibile sit de impressionibus metroloycis [sic] habere simul scientiam et opinionem. Et arguitur quod non, quia de impressionibus metheorologicis non contingit habere scientiam nec opinionem; ergo questio falsa ...X... Ad quartam: 'si galaxia non esset de natura celi, tunc de ea non esset determinandum in isto libro', condedo. Tamen Aristoteles determinavit de ea hic propter hoc quia plures antiquorum crediderunt galaxiam esse de natura elementari. Expliciunt questiones primi libri Metheororum, finite die beati Erhardi martiris atque pontificis, anno Domini 1366.

II, ff. $15^{\mathrm{vb}}-24^{\mathrm{va}}$ : Circa secundum Metheororum queritur secundum distinctionem in principio huius libri positam ab Alberto, et est questio ista: utrum locus generationis pluvie sit media regio aeris. Et arguitur quod nullum elementum debet primo generari extra locum non naturalem ...X... Ad rationes in oppositum patet ex secundo articulo. Et sic est finis questionum secundi libri Metheororum, finite in die sancti Vincentii in civitate Pragensi tunc temporis anno Domini millesimo 1366-to hora quasi crepusculi.

III, ff. $24^{\mathrm{vb}}-56^{\mathrm{rb}}$ : Circa tertium Metheororum queritur primo secundum distinctionem totius libri istius in principio positam ab Alberto. Ista sit questio prima, utrum ventus sit exalatio calida et sicca. Et arguitur primo quod non sit 
exalatio calida, quia si sic, sequeretur quod in temporibus ventosis aer deberet esse calidus ...X... Ad ultimam dico quod non in vanum laborant, ex quo aliam artem ignorant. Et sic est finis questionum tertii libri Metheororum. Finitus Prage anno Domini 1366 sabbato, die proximo ante festum purificationis Virginis gloriose.

IV, ff. $56^{\text {rb }}-64^{\text {rb: }}$ Circa quartum Metheororum queritur utrum tantum sunt quatuor qualitates prime, scilicet caliditas, humiditas, frigiditas et siccitas. Et arguitur quod non, quia quod per superhabundantiam dicitur, uni soli convenit ...X... Ad sextam dico quod in salamandra non dominatur ignis in quantitate; sed tale animal non est ustibile ab igne; et ideo, quia non uritur ab igne, dicimus quod tale animal habitet in igne, etc. Deo gratias. Expliciunt questiones quatuor librorum Metheororum Byridani, finite Prage anno Domini $13^{\circ} 66$-to in vigilia beate Dorothee virginis per pedes Johannis Krichpaumi de Ingol〈stat $\rangle$.

\section{Bibliography}

Catalogues: K. Halm, G. v. Laubmann, and W. Meyer, Catalogus codicum latinorum Bibliothecae Regiae Monacensis. I.2, Codices num. 2501-5250 complectens, Munich 1894 (Catalogus codicum manu scriptorum Bibliothecae Regiae Monacensis III.2), 181-182 [here Oresme's Questions on Meteorology are ascribed to Buridan, as in the colophon of the manuscript]; M. Markowski, Buridanica quae in codicibus manu scriptis bibliothecarum Monacensium asservantur, Wrocław/ Warsaw 1981, 70, 73-74, 94, 133; Lohr, Latin Aristotle Commentaries, I.2. Medieval Authors $M-Z: 43,258 ; 2: 35$.

Literature: P. Duhem, Le système du monde: histoire des doctrines cosmologiques de Platon à Copernic, Paris 1913-1959 (10 vols.), 4: 129ss.; Agrimi, Le "Quaestiones de sensu"; Michael, Johannes Buridan, 2: 639-640, 661, fn. 10, 736; J. Agrimi, "Les Questions de sensu attribuées à Albert de Saxe. Quelques remarques sur les rapports entre philosophie naturelle et médecine chez $\mathrm{Bu}-$ ridan, Oresme et Albert", in J. Biard (ed.), Itinéraires d'Albert de Saxe. ParisVienne au XIV siècle. Actes du colloque organisé le 19-22 juin 199o dans le cadre des activités de l'URA 1085 du CNRS à l'occasion du 600 anniversaire de la mort d'Albert de Saxe, Paris 1991 (Études de philosophie médiévale, 69), 191-204, esp. 193; Streijger, Bakker, and Thijssen (eds.), John Buridan Quaestiones super libros De generatione et corruptione Aristotelis, 17.

\section{München, Bayerische Staatsbibliothek, Clm 17226, ff. $1^{r a}-140^{r b}\left(\mathrm{M}^{1}\right)$}

Paper; mm 310 × 215; ff. 140 + III; 1413

Date and origin. The colophon informs us that the text was copied in 1413 by a certain Lanzman: "Et sic est finis huius operis. Deo gratias, etc. Et questiones 
ille scripte sunt per Lanzman ... suo domino sub anno incarnationis domini Iesu Christi M CCCC XIII ${ }^{\circ}$ etc." (f. $14 \mathrm{O}^{\mathrm{rb}}$ ).

Composition. Pasteboard binding covered with leather. On the front cover a medieval hand has written: "Questiones Metheororum Burydani in primo, in secundo et in quarto libro. Questiones Metheororum Orem(?) in primo, in tertio et in quarto libro". The volume consists of 140 paper leaves grouped in senions according to the following formula: I $(1-12)^{6+6}$; II $\left(13^{-24}\right)^{6+6}$; III $\left(25^{-36}\right)^{6+6}$; IV $\left(37^{-48}\right)^{6+6}$; V $(49-60)^{6+6}$; VI $(61-72)^{6+6}$; VII $\left(73^{-84}\right)^{6+6}$; VIII $\left(85^{-96}\right)^{6+6}$; IX $(97-108)^{6+6}$; x (109-120 $)^{6+6}$; XI (121-132 $)^{6+6}$; XII $(133-140 c)^{6+(6-1)}$. Catchwords on the verso leaves at the end of the fascicules: f. 12 , f. 24 , f. 36 , f. 48 , f. 6 , f. 72 , f. 96 , f. 108 , f. 120 . Signatures on the recto leaves at the beginning of the fascicules: f. 13 (secundus); f. 25 (tertius); f. 37 (quartus). Modern foliation in black pen and pencil. The last three leaves are blank and have not been numbered.

Content. This manuscript contains a compilation of questions on Aristotle's Meteorology based on the commentaries of John Buridan, Nicole Oresme and Themo Iudeus. In the first two books, we find an alternation of Oresme's and Buridan's questions; starting from the third book, the compilator also introduces some excerpts from Themo. In his catalogue of commentaries on Aristotle at the Bavarian State Library, Markowski attributes the whole text to John Buridan, probably having been misled by the incipit, which does indeed correspond to that of Buridan. ${ }^{48}$ (f. $1^{\text {ra: }}$ " $\langle\mathrm{S}\rangle$ i scientiam oppinamur honorabiliorem ex eo ceteris paribus quod est de magis mirabilibus ..."). ${ }^{49}$ However, as has been pointed out by Birkenmajer, the explicit does not correspond to the other manuscripts of Buridan's text, ${ }^{50}$ but rather to the second redaction of Oresme's Questions (f. 140 ${ }^{\text {ra: }}$ "Ad sextam dico quod in salamandra non dominatur ignis in quantitate nec etiam nutritur igne, sed tale animal non est ustibile ab igne; et ideo, quia non uritur ab igne, dicitur quod tale animal habitat in igne").51 The compilator does not make an effort for consistency, as he does not omit the frequent references in Buridan's questions that point to passages in the

48 Markowski, Buridanica, 72-73, 140.

49 The prologue and the first book of Buridan's Questions on Meteorology have been edited by S. Bages in her doctoral dissertation: S. Bages, Les Questiones super tres libros Metheororum Aristotelis de Jean Buridan. The prologue can be consulted in vol. 2:1-2.

The list of these manuscripts can be consulted in E. Faral, "Jean Buridan: notes sur les manuscrits, les éditions et le contenu de ses ouvrages", Archives d'histoire doctrinale et littéraire du Moyen Âge 21 (1946), 1-53, esp. 22-24, and in Bages, Les Questiones super tres libros Metheororum Aristotelis de Jean Buridan, 1: 185-188.

51 The explicit of Buridan's Questions is as follows: "sive lapidibus sive plantis sive animalibus sive earum principiis et metallis et aliis". For the different forms in which this explicit is 
original text, rendering them completely meaningless after the process of interpolation. For example, in question I.11 we read: "Sicut de motu quesitum est, ita quinto querimus de lumine, videlicet utrum omne lumen sit calefactivum", f. $18^{\text {rb. }}$.

The text is copied in a single hand in two columns of about forty lines per page. The handwriting is regular and easily readable. The decoration has not been completed: the space intended for the initials of the first (f. $1^{\text {ra }}$ ) and of the third (f. $\left.91^{\mathrm{vb}}\right)$ book has been left blank. The incipit of the second (f. $63^{\mathrm{ra}}$ ) and of the fourth (f. $13 \mathrm{O}^{\mathrm{ra}}$ ) book have not been copied at all. The incipits of the questions in textualis stop at f. $9^{\text {ra }}$. From then on, a plain blank space separate the questions. Only ff. $83^{\text {va }}-84^{\text {vb }}$ and ff. $87^{\text {ra }}-91^{\text {va }}$ contain rubrics. Corrections by the copyist himself.

\section{Incipit and explicit of the books}

Prohemium, ff. $1^{\text {ra_rb}}$ : $\langle S\rangle$ i scientiam oppinamur honorabiliorem ex eo ceteris paribus quod est de magis mirabilibus et appetibiliorem, prout habetur in prohemio De anima, constat quod scientiam libri Metheororum valde reputare debemus ...X... Ex omnibus autem coarticulatis fieri magnitudine aliqua. Sequitur nunc questio prima.

I, ff. $1^{\text {rb }}-63^{\text {ra }}:\langle\mathrm{C}\rangle$ irca materiam, utrum de impressionibus metheorologicis sit tradenda scientia naturalis distincta a scientia De celo et mundo, De generatione et corruptione, De mineralibus et De animalibus et animatis. Arguitur primo quod non sit scientia de eis ...X... De alio loquendo ad illum. Et hec sufficiant de ista materia. Et sic est finis primi libri Methaurorum. Sequitur.

II, ff. $63^{\text {ra }}-91^{\text {va: }}$ Iam de mari quesita fuerunt multa super primum librum, sed adhuc super secundum queritur de perpetuitate vel generatione maris, scilicet utrum fuit perpetuum vel aliquando factum. Et arguitur quod non ...X... Inflamabantur et ardebant consequenter grossiora. Hec ergo sint dicta de hac materia. Sequitur questio. Et sic est finis illarum questionum predictarum, etc.

III, ff. $91^{\mathrm{vb}}-130^{\text {ra }}:\langle\mathrm{C}\rangle$ irca tertium librum Metheororum queritur utrum omnis radius visualis reffrangatur in occursu medii densioris vel radioris [sic]. Arguitur primo quod non ...X.... Ad ultimam dicendum quod omnino in vanum laborant, ex quo aliam artem ignorant. Expliciunt questiones libri Methaurorum, primi, secundi et tertii; sequuntur quarti.

IV, ff. $130^{\text {ra }}-140^{\text {rb }}$ : Utrum tantum quatuor sint qualitates prime, scilicet caliditas, humiditas, frigiditas et siccitas. Et arguitur primo quod non: quod per

transmitted in the manuscripts, see Bages, Les Questiones super tres libros Metheororum Aristotelis de Jean Buridan, 1: 148-177. 
superhabundantiam dicitur, uni soli convenit ...X... Ad sextam dico quod in salamandra non dominatur ignis in quantitate nec etiam nutritur igne; sed tale animal non est ustibile ab igne; et ideo, quia non uritur ab igne, dicimus quod tale animal habitat in igne, etc. Et sic est finis huius operis. Deo gratias, etc. Et questiones ille scripte sunt per Lanzman ... suo domino sub anno incarnationis Domini nostri Jesu Christi $\mathrm{M}^{\circ} \mathrm{CCCC}^{\circ} \mathrm{XIII}$, etc.

\section{Bibliography}

Catalogues: K. Halm, G. von Laubmann, and W. Meyer, Catalogus codicum latinorum Bibliothecae Regiae Monacensis. IV.3, Codices num. 15121-21313 complectens, Munich 1878 (Catalogus codicum manu scriptorum Bibliothecae Regiae Monacensis IV.3), 89; Markowski, Buridanica, 72-73, 140; Lohr, Latin Aristotle Commentaries, I.2. Medieval Authors M-Z: 35 .

Literature: Birkenmajer, Études d'histoire des sciences en Pologne, 193; Bages, Les Questiones super tres libros Metheororum Aristotelis de Jean Buridan, 1: 176177; Michael, Johannes Buridan, 2: 656-657; Panzica, "Nicole Oresme à la Faculté des Arts de Paris", 35 and 73-78 [list of questions with indication of their sources].

\section{Paris, Bibliothèque Nationale de France, lat. 15156, ff. $226^{r}-265^{v}(\mathrm{P})$}

Paper; mm 225×15o; ff. II+227+II; ca. 1369

Date and origin. The manuscript belonged to the Library of Saint Victor at the University of Paris (f. $34^{\mathrm{r}}$, $m g$. inf:: "Iste liber est Sancti Victoris parisiensis. Cuicumque eum furatus fuerit vel tolaverit vel titulum istum deleverit anathema sit. Amen"). On the verso of the second parchment guard leaf, we find an old signature: "n.n.2o". In the upper margin of the first paper leaf (numbered 26), we find three numbers (probably old signatures) written by modern hands: "288" (crossed out), "729" and "c.2.20". On the same line, a modern hand has written: "S. Victor 514 ". One of the texts contained in this manuscript is dated 1369 (f. $34^{\mathrm{v}}$ : "anno Domini 1369").

Composition. Wooden binding covered with leather. Traces of two pegs on the front cover. On the inside cover, we find a paper rectangle with the following modern inscription: "Volume de 288 feuillets. Moins les feuillets 3-26, 28-31, 194-226. Les feuillets 32, 33, 56, 59, 181-266 sont blancs. Le feuillet 1 est mutilé. 10 Mai 1869". Two parchment guard-leaves. On the verso of the second leaf, a medieval hand has written: "Tabulam hic contentorum reperies folio 297". The folio number was thereafter erased by a modern hand, which wrote on the same line " 31 ". On the same parchment leaf, we find an old signature: "n.n.2o". The guard-leaves are followed by 227 paper leaves grouped mainly in senions: I $\left(3^{-} 33\right)^{(3-1)+3}$; II $(34-45)^{6+6}$; III $(46-57)^{6+6}$; IV $\left(5^{8-69}\right)^{6+6}$; V $(70-81)^{6+6}$; VI 
$(82-93)^{6+6}$; VII $(94-105)^{6+6}$; VIII $(106-117)^{6+6}$; IX $(118-129)^{6+6}$; x (130-141 $)^{6+6}$; XI $(142-153)^{6+6}$; XII $\left(154^{-165}\right)^{6+6}$; XIII $(166-177)^{6+6}$; XIV $(178-181)^{2+2}$; XX (182$193)^{6+6}$; XXI $(226-237)^{6+6}$; XXII $(238-247)^{6+6}$; XXIII $(248-259)^{6+6}$; XXIV (26o$271)^{6+6}$; $\mathrm{xxV}(272-285)^{7+7}$; Xxvi three folios. At the end of the volume some leaves have been cut off (nine, as we can infer from the numbering of the following leaf). Two parchement guard-leaves, numbered by a medieval hand 298 and 299. Signatures in the upper margin of each recto leaf: f. 34 (primus 6); f. 46 (2us); f. 58 (3us); f. 70 (4us); f. 82 (5us); f. 94 (6us); f. 106 (7us); f. 118 (8us); f. 130 (gus); f. 142 (1ous); f. 154 (11us); f. $166^{\text {r }}$ (12us); f. 178 (13us). Catchwords in the inner lower margin of the verso leaves: f. 45; f. 69; f. 81; f. 93; f. 105; f. 117; f. 129; f. 141; f. 153 ; f. 165 ; f. 177 ; f. 259 ; f. 237 ; f. 247 ; f. 271 ; f. 285 .

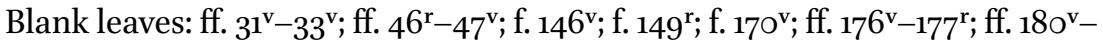

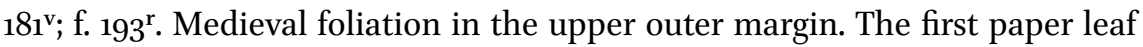
is numbered 26 , as leaves $1-25$ have been torn out. A modern hand added " 3 " before " 26 ", in order to make clear that the preceding leaves were missing. The same hand numbered the two parchment guard-leaves 1 and 2. Folio 27 is followed by f. 31. The modern hand wrote "28-" before 31, to make clear that folios $28-30$ were missing. Ff. 34-181 must have circulated independently in the Middle Ages, as they are consecutively numbered with another foliation. This foliation has been crossed out. F. 193 is followed by f. 226. A modern hand has written "194-" before 226, to make clear that ff. 194-225 were missing.

Content. This manuscript gathers various heterogeneous texts. On f. $31^{r}$, a modern hand has compiled a table of contents: "Tabula contentorum / Metra quedam fol. 26 / Plura theologicalia a fol. 44 usque 180 / tractatus quidam de consequentiis 183 / Questiones super librum Metheororum 226". The table is followed by a list of missing texts: "Desiderata in hoc codice / Tractatus quidam de Rhetorica fol. 2 / Epistola Luciferi ad prelatos Ecclesie 28 / Aristotelis Secreta secretorum sive De regimine principum 194". I have identified the verses on ff. $26^{\mathrm{r}}-27^{\mathrm{v}}$ as Geoffroi of Vinesauf's Poetria nova. ${ }^{52}$ The second text contained in this codex (the Plura theologicalia) is a commentary on the Sentences. A fifteenth-century hand, different from that of the copyist, ascribes it to John Gerson (f. 178v: "Sententie magistri Joannis Gerson"). This ascription is accepted by A. Combes ${ }^{53}$ and contested by Glorieux, who ascribes this commentary

52 J.V. Le Clerc, B. Hauréau, and P. Meyer (eds.), Histoire littéraire de France, XIII e siècle, 18, Paris $1835,305^{-311 .}$

53 A. Combes, "Note sur les Sententiae MagistriJoannis Gerson du manuscrit B.N.LAT. 15156", Archives d' histoire doctrinale et littéraire du Moyen Âge 14 (1939), 365-385. 
to Jean Régis, a Franciscan who lectured on the Sentences in the academic year $1369-1370 .{ }^{54}$ The third text, on $\mathrm{ff} .182^{\mathrm{r}}-192^{\mathrm{v}}$, is a treatise on logic in ten chapters. ${ }^{55}$

The Questions on Meteorology. The text, which is transmitted anonymously, is copied in a single column of about forty lines per page. The handwriting, typical of mid-fourteenth-century Paris, is regular and easy to read. The large initials that should appear at the beginning of each question are missing. The first words of the books and of the questions are copied in textualis, as are the words that introduce a new part of the question ("in oppositum, quantum ad primum, ad rationes"). The text stops, unfinished, on f. $288^{v}$, at question III.2O (Utrum omni hora dieiyris posset apparere), with the words: "quod semper semidyameter iridis est equalis, ideo dicendum est quod hoc est". A first interruption occurs on $\mathrm{f} .265^{\mathrm{v}}$, at question II.10 (Utrum mare debeat fluere et refluere), with the words: "eius a Sole augetur eius virtus a Sole"; the commentary resumes on f. $267^{\mathrm{r}}$, with the question Utrum aqua maris debeat esse salsa, f. 266 having been left blank. McCluskey has noticed that, starting from this question, the text no longer follows Oresme's Questions, but rather Albert of Saxony's. The collation of the Parisian commentary with the other witnesses of Albert's commentary enabled me to confirm this statement, ${ }^{56}$ which nonetheless requires some clarification. While the third book of Albert's Questions only contains nine questions, the Parisian manuscript consists of twenty. This can easily be explained by the different division of the books adopted in the Parisian manuscript: while in Albert's manuscripts the question Utrum ventus sit exalatio calida et sicca is the seventh of the second book, in the Parisian manuscript it is placed at the beginning of the third book. The Questions on Meteorology contained in this manuscript is therefore a compilation consisting of questions I.1-II.10 by Nicole Oresme and questions II.11-III.9 by Albert of Saxony.

Incipit and explicit of the books

I, ff. $226^{\mathrm{r}}-253^{\mathrm{r}}$ : $\langle\mathrm{C}\rangle$ irca librum Metheororum, qui est quartus naturalium, queritur primo utrum possibile sit de impressionibus metheorologicis habere simul scientiam et opinionem. Et arguitur primo quod non: de impressionibus metheorologicis non contingit habere scientiam nec etiam opinionem; ergo

54 P. Glorieux, "Le Commentaire sur les Sentences attribué à Jean Gerson", Recherches de théologie ancienne et médiévale 18 (1951), 128-139. Glorieux has shown that the principia, the commentary on the Sentences, and the table of contents, which are written in the same hand, form a textual unity (134-135). He also identified the masters referred to in the principia of the commentary (133).

55 Inc:: "Benivolentia theologorum studentium me compulit".

56 For the other manuscripts of Albert's Questions on Meteorology see Panzica, "Albert of Saxony's Questions on Meteorology", 248-256. 
questio falsa ...X... Ad quartam: 'si esset de natura celi, de ea non esset determinandum', concedo. Sed tamen Aristoteles determinavit de ea hic propter hoc quod plures antiquorum crediderunt galachiam esse de natura elementari. Et sic patet ad questionem.

II, ff. $253^{\mathrm{v}}-269^{\mathrm{r}}$ : $\langle\mathrm{C}\rangle$ irca secundum librum Metheororum queritur utrum locus generationis pluvie sit media regio aeris. Et arguitur primo quod non: nullum elementum debet generari extra locum sibi naturalem ...X... Ratio in oppositum soluta est, quia considerabatur quod radii Solis sunt causa salsedinis, et intelligebatur de salsedine maris. Hoc de questione.

III, $269^{\mathrm{r}}-288^{\mathrm{v}}$ : $\langle\mathrm{C}\rangle$ irca tertium librum Metheororum queritur utrum ventus sit exalatio calida et sicca. Et videtur primo quod sit aer motus, quia aliquis motus est ventus, ut patet in follibus ...X... Semper semidiameter yridis est equalis, ideo dicendum est quod hoc est ...

\section{Bibliography}

Catalogues: L. Delisle, Inventaire des manuscrits de l'Abbaye de Sainct-Victor conservés à la Bibliothèque Impériale, sous les numéros 14232-15175 du fonds latin, Paris 1869, 76-77; W. Seńko, Repertorium commentariorum Medii Aevi in Aristotelem Latinorum quae in bibliothecis publicis Parisiis asservantur (Bibliothèque Nationale, Arsenal, Mazarine, Sorbonne, Ste Geneviève), Warsaw 1982, 192-193; G. Ouy, Les manuscrits de l'Abbaye de Saint-Victor: catalogue établi sur la base du répertoire de Claude de Grandrue (1514), Turnhout 1999 (Bibliotheca Victorina, 10) (2 vols.), 2: 341; Lohr, Latin Aristotle Commentaries, I.2. Medieval Authors M$Z: 35$.

Literature: A. Combes, "Note sur les Sententiae Magistri Joannis Gerson du manuscrit B. N. LAT. 15156", Archives d'histoire doctrinale et littéraire du Moyen Âge 14 (1939), 365-385; P. Glorieux, "Le Commentaire sur les Sentences attribué à Jean Gerson”, Recherches de théologie ancienne et médiévale 18 (1951), 128-139; L. Thorndike, "Oresme and Fourteenth Century Commentaries on the Meteorologica", Isis 45 (1954), 145-152 [list of questions at pp. 150-152]; McCluskey, Nicole Oresme on Light, Color and the Rainbow, 34, fn. 3, 97-98; Panzica, "Nicole Oresme à la Faculté des Arts de Paris", 34.

\section{Poznań, Archivum Archidiecezjalne, Cms 53, ff. ${ }^{r_{-}}{ }^{2}{ }^{v}(\mathrm{Po})$}

Paper; mm 205×150; I+368+I; 15 th C

Date and origin. Nothing is known about the date or provenance of this codex, except that it belonged to the Cistercensian friars, as is evident from a note on f. $\mathrm{r}^{\text {ra: }}$ "Ex libris fratrum B.M.v. de [...] Ord. Cisterc".

Codicology. Medieval wooden binding. The front cover is missing. A clasp on the back cover. A parchment guard-leaf followed by 368 paper leaves grouped 
mainly in senions, according to the following scheme: I $(1-12)^{6+6}$; II $\left(13^{-24}\right)^{6+6}$; III $\left(25^{-36}\right)^{6+6}$; IV $(37-48)^{6+6} ; \mathrm{V}(49-60)^{6+6}$; VI $(61-70)^{5+5}$; VII $(71-82)^{6+6}$; VIII $\left(83^{-94}\right)^{6+6}$; IX $\left(95^{-107}\right)^{7+(7-1)}$; X (108-119) ${ }^{6+6}$; XI $(120-131)^{5+5}$; XII $\left(13^{2-143}\right)^{6+6}$; XIII $(144-155)^{6+6} ; \operatorname{XIV}\left(15^{6-167}\right)^{6+6} ;$ XV $(168-179)^{6+6} ;$ XVI $(180-191)^{6+6}$; XVII (192$207)^{8+8}$; XVIII $(208-219)^{6+6}$; XIX $(220-231)^{6+6}$; XX $\left(23^{2-243}\right)^{6+6}$; XXI $\left(244^{-}\right.$ $\left.25^{\circ}\right)^{4+(4-1)}$; XXII $\left(25^{-262}\right)^{6+6}$; XXIII $\left(263^{-274}\right)^{6+6}$; XXIV $\left(275^{-286}\right)^{6+6} ; \operatorname{XXV}$ $(287-298)^{6+6}$; XXVI $(299-310)^{6+6} ; \operatorname{XXVII}(311-322)^{6+6} ; \operatorname{XXVIII}(323-334)^{6+6}$; XXIX $\left(335^{-346}\right)^{6+6}$; XX $\left(347-35^{8}\right)^{6+6}$; XXI $\left(359^{-368}\right)^{6+(6-2)}$. At the end of the volume we find another parchment guard-leaf.

Three main codicological units can be distinguished: I (ff. 1-95); II (ff. 96248); III (ff. 251-367). In the first unit, we find signatures in the inner margin of the first leaf of each fascicule: f. 13 (2us); f. 25 (3us); f. 37 (4us); f. 49 (5us); f. 61 (6us); f. 71 (7us); f. 83 (8us). In the second codicological unit, the signatures can be found sometimes in the inner, sometimes in the upper margin, between the two columns: f. 110 (2); f. 120 (3); f. 132 (4us); f. 144 (5us); f. 156 (6us); f. 168 (7us); f. 18o (8us); f. 192 (nonus); f. 208 (decimus); f. 220 (undecimus, upper margin between the two columns); f. 232 (12us, upper margin between the two columns); f. 244 (13us). Finally, in the third codicological unit, the signatures are always in the upper central margin: f. 263 (2us); f. 275 (3us); f. 287 (4us); f. 299 (5us); f. 311 (6us); f. 323 (7us); f. 335 (8us); f. 347 (gus); f. 359 (1ous). Modern foliation in pencil in the upper outer margin, every ten leaves. Ff. $148^{\mathrm{v}}-15^{0^{\mathrm{v}}}$ and ff. $267^{\mathrm{v}}-268^{\mathrm{v}}$ are blank.

Content. Three textual units correspond to the three codicological units of this manuscript. The first part $\left(\mathrm{ff} .1^{\mathrm{r}}-95^{\mathrm{v}}\right)$ contains the second redaction of Oresme's Questions on Meteorology; the second part (ff. $96^{\mathrm{r}}-248^{\mathrm{r}}$ ), a set of anonymous Questions on the Physics; the third part $\left(\mathrm{ff} .25^{\mathrm{r}}-367^{\mathrm{r}}\right)$, Lawrence of Lindores's Questions on De anima. ${ }^{57}$

The Questions on Meteorology. The text is anonymous. In his catalogue of commentaries on Aristotle in Poznan's Libraries, Markowski ascribes it to John Buridan, without justifying this choice. Yet the incipits and the explicits of the books do not correspond to Buridan's text, but to the second redaction of Oresme's Questions on Meteorology. Moreover, Buridan did not comment on the fourth book of Aristotle's Meteorology, while Oresme did. Following a direct study of the text, we can now confirm that it is a copy of the second redaction of Oresme's Questions on Meteorology. 
The text is written in different hands and laid out in two columns of about forty-eight lines each. There is no decoration. The words that introduce the structural parts of the questions are sometimes written in bigger character; in other cases, these words are missing and replaced by a blank space. Nine questions from the third book are missing: III.24-III.32. At the end of question III.32 (f. $78^{\text {va }}$ ), the copyist has written: "Item sequuntur adhuc decem questiones, scilicet inter illam 'supposito quod yris fiet secundum reflexionem', et illam 'utrum, visa yride et Sole'. This note is followed by a blank space of eleven lines. The scribe then resume the copy with question III.33 (Utrum, visa yride et Sole vel astro elevato notabiliter super horizontem, apparet minor portio maioris circuli quam appareat Sole existente in fine horizontis).

Incipit and explicit of the books

I, ff. $1^{\text {ra }}-29^{\text {vb: }}$ Queritur primo utrum possibile sit de impressionibus meteoroloycis $[$ sic $]$ simul habere scientiam et opinionem. Et arguitur primo quod non, quia de impressionibus metheorologicis non contingit habere scientiam nec opinionem; ergo etc. ...X... Ad quartam: 'si galaxia non esset de natura celi, tunc de ea non esset determinandum in isto libro', concedo. Et cum dicitur: 'tamen Aristoteles determinavit de ea hic', respondetur quod hoc fecit propter hoc quod plures antiquorum crediderunt galaxiam esse de natura elementari, et propter eorum opiniones ipse talem materiam hic tegit. Et sic est finis questionum primi libri Metheororum.

II, ff. $29^{\mathrm{vb}}-44^{\mathrm{vb}}$ : Circa secundum librum Meteororum queritur primo utrum locus generationis pluvie sit media regio aeris. Et arguitur primo quod non: nullum elementum debet generari extra locum sibi naturalem ...X... Ad rationes ante oppositum patet ex secundo articulo. Et sic est finis secundi libri, etc. Sequitur tertius liber.

III, ff. $45^{\text {ra }}-85^{\text {ra: }}$ Queritur primo utrum ventus $\langle$ sit $\rangle$ exallatio calida et sicca. Et arguitur primo quod non sit exallatio calida, nam sic sequeretur quod in temporibus ventosis aer deberet esse calidus ...X... Ad ultimam dico quod non in vanum laborant, ex quo aliam artem ignorant. Sequitur quartus.

IV, ff. $85^{\text {ra }}-95^{\text {va: }}$ Circa initium quarti libri Methaurorum queritur primo utrum tantum quatuor sunt qualitates prime, scilicet caliditas, humiditas, siccitas et frigiditas. Et arguitur primo quod non, quia quod $\langle$ per $\rangle$ superhabundantiam dicitur, uni soli convenit ...X... Ad sextam dico quod in salamandra non dominatur ignis in quantitate nec nutritur ab igne; sed tale animal non est combustibile ab igne; et ideo dicimus quod ipsum habitat in igne. Et sic est finis.

\section{Bibliography}

Catalogues: A. Lisiecki, Katalog rękopisów bibliotecki seminarynej w Poznaniu, Poznań 1905, 30; Markowski, "Aristotelica Poznaniensia", 289-29o. On the 
manuscript collection of the Diocesan Archiv of Poznan, see T. Makowski, Rękopisy w zbiorach kościelnych, Warsaw 2014 (Zbiory rękopisów w Polsce, 2), 279-293.

Literature: Panzica, "Commenter les Météorologiques à l'Université de Cracovie", 84, 103, 16o; Ead., "Henricus Totting de Oyta's and Nicole Oresme's Commentaries on Meteorology: Some New Identifications in Eastern Europe", Bulletin de philosophie médiévale 62 (2020), 195-211, at 200, n. 7.

St. Gallen, Stiftsbibliothek, Cod. Sang. 839, ff. $1^{r}-177^{r}(\mathrm{Sg})$

Paper; mm 220 × 165; ff. 180; 1459

Date and origin. This manuscript was copied in 1459, as stated by the colophon: "Rescripte sunt hee questiones venerabilis magistri Orem Metheororum Aristotelis paripatetici $[s i c]$ anno domini 1459 pridie idus mensis septembris indictione septima" (f. $175^{\mathrm{v}}$ ). A scribe's marginal note in Middle High German proves that the codex was copied in a German speaking region (f. $54^{\text {r: }}$ "Is Schiff ist gut"). The same scribe copied another manuscript conserved in St. Gallen: ms. 840, which contains Nicholaus Theoderici of Amsterdam's Questions on Aristotle's Metaphysics. The manuscript belonged to the library of the monastic community of St. Gallen already in the sixteenth century, as witnessed by the coat of arms of Prince-Abbot of St. Gallen Diethelm Blarer (1530-1564), on f. $175^{\mathrm{v}}$.

Composition. The binding, restored in the eighteenth century, is made of leather and pasteboard. The first leaf, numbered A in pencil by a modern hand, was probably added afterwards, as it has not been numbered by the medieval hand and as the subsequent leaf is rather worn, which indicates that it was previously the first leaf of the volume. Pius Kolb, an eighteenth-century librarian, has written on this leaf: "Tractatus egregius seu questiones in IV libros Metheororum Aristotelis". In the upper margin of the same leaf, Kolb entered the signature "s.n.308", under which the manuscript was registered in an old catalogue of 1755 . The old signature is followed by the modern one, " 839 ", written in red ink.

The volume consists of fifteen senion quires: I (A-11 $)^{6+6}$; II $(12-23)^{6+6}$; III $(24-35)^{6+6} ; \mathrm{IV}(36-47)^{6+6} ; \mathrm{V}(48-59)^{6+6}$; VI $(60-71)^{6+6}$; VII $(72-84)^{6+6}$; VIII $\left(85^{-}\right.$ $96)^{6+6}$; IX $\left(97^{-108}\right)^{6+6}$; x $(109-120)^{6+6}$; XI $(121-132)^{6+6}$; XII $\left(133^{-144}\right)^{6+6}$; XIII $\left(145^{-156}\right)^{6+6} ; \operatorname{xIV}\left(157^{-168}\right)^{6+6} ; \mathrm{xV}\left(169-179^{B}\right)^{6+6}$.

Starting with the second fascicule, we find signatures in the recto lower margin of every first leaf: f. 12 (2us); f. 24 (3us); f. 36 (4us); f. 48 (5us); f. 6o (6us); f. 72 (7us); f. 85 (8us); f. 97 (gus); f. 109 (1ous); f. 121 (11us); f. 133 (12us); f. 145 (13us); f. 157 (14us); f. 169 (15us). Medieval foliation in the upper outer margin. Ff. $177^{\text {v }}$ $179^{v}$ are blank. The numbering skips from 76 to 78 . 
The Questions on Meteorology. This manuscript only contains the second redaction of Oresme's Questions on Meteorology $\left(\mathrm{ff}^{\mathrm{r}} \mathrm{1}^{\mathrm{r}}-175^{\mathrm{r}}\right)$, followed by a table of contents (ff. $176^{\mathrm{r}}-177^{\mathrm{r}}$ ). The text is copied in a single column with about forty lines per page. The handwriting is a fifteenth-century bastarda; the ink is brown. The incipits of the questions are boxed in red. The decoration is unfinished: the space intended for the initials of the books has been left blank (f. $1^{\mathrm{r}}$, f. $42^{\mathrm{v}}$, f. $67^{\mathrm{r}}$, f. $15^{2}$ ).

Incipit and explicit of the books

I, ff. $1^{r}-42^{r}$ : $\langle C\rangle$ irca primum Metheororum queritur primo utrum possibile sit de impressionibus metheorologicis habere simul scientiam et oppinionem. Et arguitur quod non, quia de impressionibus metheoroloycis non contingit habere scientiam et oppinionem; igitur questio falsa ...X... Ad quartam dico: 'si gallaxia esset de natura celi, tunc de ea non esset determinandum in isto libro', concedo. Et cum dicitur: 'tamen Aristoteles determinavit de ea', respondetur quod hoc facit propter hoc quia plures antiquorum crediderunt gallaxiam esse de natura elementari, propter eorum oppinionem ipse talem materiam hic tangit. Explicit primus Metheororum.

II, ff. $42^{\mathrm{v}}-66^{\mathrm{v}}$ : $\langle\mathrm{C}\rangle$ irca secundum Metheororum queritur primo utrum locus generationis pluviarum sit media regio aeris. Et arguitur primo quod non, nam nullum elementum debet generari extra suum locum naturalem ...X... Rationes patent in secundo articulo huius questionis.

III, ff. $67^{\mathrm{r}}-15^{2} \mathrm{v}$ : $\langle\mathrm{C}\rangle$ irca tertium Metheororum queritur, secundum distinctionem istius totius in principio positam ab Albertho, utrum ventus sit exalatio calida et sicca. Et arguitur quod non sit exalatio calida et sicca, nam sic sequeretur quod in temporibus ventosis aer deberet esse calidus ...X... Ad ultimam dico quod non in vanum laborant, ex quo aliam artem ignorant. Et sic finis est questionum tertii Metheororum Aristotelis.

IV, ff. $15^{2}-175^{\mathrm{v}}:\langle\mathrm{C}\rangle$ irca quartum Metheororum queritur primo utrum tantum quatuor sint qualitates prime, scilicet caliditas, humiditas, frigiditas, siccitas. Et arguitur primo quod non, quia quod per superhabundantiam dicitur, uni soli convenit ...X... Ad sextam dico quod in salamandra non dominatur ignis in quantitate nec etiam nutritur ab igne; sed tale animal non est ustibile ab igne; et ideo, quia non uritur ab igne, dicimus quod tale animal habitet in igne, et non quod nutriatur ab igne vel quod in eo dominetur $\left[175^{\mathrm{v}}\right]$, sed illo modo quo dictum est, scilicet quod sit inustibile ab ipso igne. Et sic finis est huius libri, de quo fine laudetur Deus gloriosus in secula benedictus. Amen. Rescripte sunt hee questiones venerabilis magistri Orem supra libris Metheororum Aristotelis paripotetici $[s i c]$ anno domini 1459 , pridie ydiis mensis septembris, indictione septima. 


\section{Bibliography}

Catalogues: G. Scherrer, Verzeichniss der Handschriften der Stiftsbibliothek von St. Gallen, Halle 1875, 285; B.M. von Scarpatetti, R. Gamper, and M. Stähli, Katalog der datierten Handschriften in der Schweiz in lateinischer Schrift vom Anfang des Mittelalters bis 1550, 3: Die Handschriften der Bibliotheken St. Gallen-Zürich, Dietikon/Zurich 1991, nr. 195, 71; Ch. Lohr, Aristotelica Helvetica, 259-26o; Lohr, Latin Aristotle Commentaries. Medieval Authors, 2: 35.

Literature: H. Suter, "Eine bis jetzt unbekannte Schrift des Nic. Oresme", Zeitschrift für Mathematik und Physik, 27 (1882), Hist.-Lit. Abteilung, 121-125; L. Thorndike, "More Questions on the Meteorologica", Isis 46 (1955), 357-36o.

Paper; mm 310 × 220; ff. 313; 1424

Date and origin. The colophon of the Questions on Meteorology informs us that the text was copied in 1424 (f. $96^{\mathrm{v}}$ : "Anno MCCCC $24^{\circ}$ "). The manuscript may have originated in Germany. It belonged to the monastery of Vadstena in Swabia until the latter was abandoned in 1595. The manuscript was then bought by the King of Sweden. In 1620, king Gustavus Adolphus of Sweden donated it to the University library of Uppsala.

Composition. See M. Andersson-Schmitt, H. Hallberg, and M. Hedlund, Mittelalterliche Handschriften der Universitätsbibliothek Uppsala, Katalog über die C-Sammlung, 6: Handschriften C 551-935, Stockholm 1995 (Acta Bibliothecae Regiae Universitatis Upsaliensis, 26), 8o-81.

Content. The manuscript contains two texts: the second redaction of Oresme's Questions on Meteorology (ff. $2^{\mathrm{r}}-97^{\mathrm{r}}$ ), followed by Marsilius of Inghen's Questions on the Metaphysics (ff. $98^{\mathrm{r}}-308^{\mathrm{v}}$ ).

The Questions on Meteorology. The colophon ascribes the commentary to Guillaume Oresme: "Et sic est finis quarti libri Metheorologicorum reverendi magistri Wilhelmi de Orem" (f. $96^{v}$ ). The text is laid out on two columns of about forty-five lines each. The ink is brown; the handwriting regular. Rubrics and rubricated pilcrows. The first words of the questions are copied in textualis. The words that refer to the argumentative structure of the text are sometimes highlighted in red, as are other parts of the text that were probably regarded as important (see for example f. $3^{\mathrm{v}}$ ). In the margins, we find brief annotations in red, which refer to the structure of the text. Large initials in red at the beginning of the books. On f. $97^{r-v}$, we find a table of contents written by the hand of the copyist.

Incipit and explicit of the books

I, ff. $2^{\text {ra }}-23^{\text {vb: }}$ Metrorum [sic] questiones. Incipiendo ita queritur primo utrum possibile sit de impressionibus metroloycis [sic] simul habere scientiam 
et opinionem. Et arguitur primo quod non, quia de impressionibus metroloycis $[s i c]$ non contingit habere scientiam ...X... Ad quartam: 'si galaxia esset de natura celi, tunc de ea non esset in illo libro determinandum', concedo. Sed tamen Aristoteles declarat de ea hic propter hoc quia plures antiquorum crediderunt quod galaxia esset de natura elementari. Et sic est $\langle$ finis $\rangle$ questionum primi libri.

II, ff. $24^{\text {ra }}-36^{\text {ra }}$ : Apud initium secundi libri Metheororum, secundum distinctionem in principio illius positam ab Alberto, sit prima questio illa: utrum locus generationis pluvie sit media regio aeris. Et arguitur quod non: nullum elementum debet generari extra locum sibi naturalem ...X... Ad rationes ante oppositum patet ex secundo articulo. Et sic est finis questionum secundi Metheororum.

III, ff. $36^{\text {ra }}-81^{\text {va }}$ : Circa tertium librum Metheororum sit prima questio illa, utrum ventus sit exalatio calida et sicca. Et arguitur primo quod non sit exalatio calida, nam sic sequeretur quod in temporibus ventosis aer deberet esse calidus ...X... Ad ultimam dico quod non in vanum laborant, ex quo alia arte ignorant, etc. Et patet questio. Et sic est finis questionum tertii libri Metheororum.

IV, ff. $81^{\mathrm{vb}}-96^{\mathrm{vb}}$ : Nunc circa quartum Metheororum primo queritur utrum tantum quatuor sunt qualitates prime, scilicet caliditas, humiditas, siccitas et frigiditas. Et arguitur quod non, quia quod per habundantiam dicitur, uni soli rei convenit ...X... Ad sextam dico quod in salamandra non dominatur ignis in quantitate nec etiam nutritur ab igne; sed tale animal non est combustibile ab igne; et ideo, quia non comburitur ab igne, dicimus quod ipsum habitet in igne, etc. Et sic est finis quarti libri Metheorologicorum reverendi magistri Wilhelmi de Orem.

\section{Bibliography}

Catalogues: Andersson-Schmitt, Hallberg, and Hedlund, Mittelalterliche Handschriften der Universitätsbibliothek Uppsala, Katalog über die C-Sammlung, 6, 80-81; P.O. Kristeller, Iter Italicum, 5: Alia itinera III and Italy III, Sweden to Yugoslavia, Utopia, Supplement to Italy $(A-F)$, London 1963, 20; Lohr, Latin Aristotle Commentaries. Medieval Authors, 2: 35 .

Literature: Birkenmajer, Études d'histoire des sciences en Pologne, 193; McCluskey, Nicole Oresme on Light, Color, and the Rainbow, 95.

Paper; mm 330 × 225; ff. 109; 1370

Date and origin. The colophon of Buridan's Questions on De generatione et corruptione informs us that the text was written in Prague in 1370: "Expliciunt questiones magistri Biridani super De generatione et corruptione reportate Prage sub 
anno millesimo $\mathrm{C}^{\circ} \mathrm{C}^{\circ} \mathrm{C}^{\circ} \mathrm{LXX}{ }^{\circ}$ in die sancti Petri ad vincula" (f. $48^{\mathrm{v}}$ ). Like the texts in manuscript BJ 749, the commentaries contained in this codex derive from a pronuntiatio, as is witnessed by the use of the expression reportate. The material aspects of the texts confirm this hypothesis: the handwriting is hasty and there are many interruptions.

Codicology. Parchment binding. The volume contains 109 paper leaves grouped as follows: I $(1-9)^{4+(4+1)}$; II $(10-22)^{6+(6+1)}$; III $\left(23^{-29)^{5+(5-3)}}\right.$; IV (30$41)^{7+(7-2)}$; V $(42-49)^{4+4}$; VI $(50-61)^{6+6}$; VII $(62-73)^{6+6}$; VIII $(74-85)^{6+6}$; IX $(86-$ $97)^{6+6} ; \mathrm{x}(98-109)^{6+6}$. Signatures in the central upper margin of the first leaf of each fascicule: f. 10 (2); f. 23 (3); f. 30 (4); f. 42 (5); f. 50 (6); f. 62 (7); f. 74 (8); f. 86 (9); f. 98 (10). Modern foliation in the upper outer margin. Blank leaves: ff. 9-10, f. 13 , ff. $28^{\text {rb }}-29^{\mathrm{vb}}$, f. $45^{\mathrm{v}}$.

Content. The manuscript contains texts on natural philosophy by Parisian masters of the fourteenth century: some questions abbreviated from the first two books of Albert of Saxony's Questions on De celo (ff. $\left.1^{\mathrm{ra}}-8^{\mathrm{vb}}\right) ; 58$ an incomplete copy of Buridan's Questions on De anima, redactio A ( $\left.\mathrm{ff}^{1} 1^{\mathrm{ra}}-28^{\mathrm{ra}}\right)$; the redactio $B$ of Buridan's Questions on De generatione et corruptione ( $\left(\mathrm{ff} .3 \mathrm{O}^{\mathrm{ra}}-48^{\mathrm{va}}\right)$; a fragment from Albert of Saxony's Questions on Meteorology (f. $\left.48^{\mathrm{vb}}\right),{ }^{59}$ and the second redaction of Oresme's Questions on Meteorology (ff. $\left.49^{\mathrm{ra}}-109^{\mathrm{vb}}\right)$.

The Questions on Meteorology. The text, which is anonymous, is laid out in two columns of about sixty lines each. The handwriting is hasty and tight, sometimes almost unreadable (see for instance ff. $82^{\mathrm{v}}-83^{\mathrm{r}}$ ). Long marginal notes have also been written very hastily (see for instance f. $5^{2^{\mathrm{r}}}$, f. $64^{\mathrm{r}}, \mathrm{f} .106^{\mathrm{r}-\mathrm{v}}$ ). The incipits of the first and the second book are copied in textualis; the other incipits are missing. The incipits of the questions are written in textualis only until f. $67^{\mathrm{r}}$, after which a simple blank space separates the questions. In the margins of $f .79^{\mathrm{v}}$ and $f .8 \mathrm{o}^{\mathrm{r}}$, we find some rough figures drawn by the scribe in order to illustrate the geometrical demonstrations contained in the text.

$5^{8}$ Inc.: "Utrum cuilibet corpori simplici naturaliter insit unus motus. Arguitur quod non, quia celo non inest naturaliter unus simplex motus; igitur questio falsa"; I.2, Utrum in mundo sint etiam [sic] corpora distincta secundum speciem, scilicet elementa et celum, seu quinta essentia (f. $1^{\mathrm{rb}}$ ); I.3, Utrum preter elementa et celum sit pondendum sextum corpus simplex (f. $\left.1^{\mathrm{va}}\right) ;$ I.4, Utrum totalis mundus aggregatus ex quatuor corporibus simplicibus sit unum continuum (f. $1^{\mathrm{vb}}$ ); I.5, Utrum sursum et deorsum debeant capi in celo secundum polos, sic quod unus sit sursum et aliter deorsum (f. $2^{\text {ra }}$ ); I.6, Utrum polus articus nobis apparens sit sursum et aliter deorsum (f. $2^{\mathrm{rb}}$ ). The text is interrupted at the very beginning of the third book, with the words: "queritur primo circa tertium librum De celo et mundo utrum aliquod elementum", and so on. Ff. $9^{r}-10^{v}$, which were intended to host the rest of the text, have been left blank.

Panzica, “Albert of Saxony's Questions on Meteorology", 255-257. 


\section{Incipit and explicit of the books}

I, ff. $49^{\text {ra }}-63^{\text {rb: }}\langle Q \mathrm{Q}\rangle$ ueritur circa primum Metheororum utrum de impressionibus meteoroloycis possibile sit habere scientiam simul et opinionem. Et arguitur quod non, quia de eis nec contingit habere scientiam nec opinionem; igitur questio falsa ...X... Ad quartam: 'si [ $63^{\text {rb }}$ ] galaxia esset de natura celi', concedo. Sed tamen Aristoteles determinavit de ea in isto libro quia plures antiquorum crediderunt galaxiam esse de natura elementari.

II, ff. $63^{\mathrm{rb}}-71^{\mathrm{vb}}$ : $\langle\mathrm{Q}\rangle$ ueritur primo circa secundum librum Metheororum utrum locus generationis pluvie sit media regio aeris. Arguitur quod non debet generari extra locum suum naturalem ...X... Ad rationes in oppositum patet ex secundo articulo. Et sic sequitur tertius liber.

III, ff. $71^{\mathrm{vb}}-103^{\text {ra: }}$ : Utrum ventus sit exalatio calida et sicca. Et arguitur quod non sit exalatio calido [sic], quia sic sequitur quod in temporibus ventosis aer deberet esse calidus ...X... Ad ultimam dico quod non in vanum laborant, ex quo aliam artem ignorant. Et sic est finis questionum tertii libri huius.

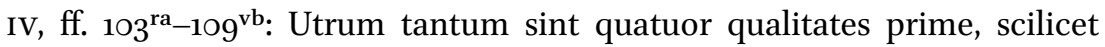
caliditas, humiditas, frigiditas, siccitas. Et arguitur primo quod non, quia quod per superhabundantiam dicitur, uni soli convenit ...X... Ad sextam dico quod in salamandra non dominatur ignis in quantitate nec etiam nutritur ab igne; sed tale animal non est ustibile ab igne; et ideo, quia non uritur ab igne, dicimus quod tale animal habitat in igne, etc. Deo gratias.

\section{Bibliography}

Catalogues: F. Unterkircher, Die datierten Handschriften der Österreichischen Nationalbibliothek von 1501 bis 1600, Vienna 1976 (Katalog der datierten Handschriften in lateinischer Schrift in Österreich 4), 208; M. Markowski, Repertorium commentariorum medii aevi in Aristotelem Latinorum quae in Bibliothecis Wiennae asservantur, Wrocław 1985, 73, 82, 83, 89, 269; Lohr, Latin Aristotle Commentaries. Medieval Authors, 1: 258; 2: 35 .

Literature: Michael, Johannes Buridan, 2: 641, 689; Streijger, Bakker, and Thijssen (eds.), John Buridan Quaestiones super libros De generatione et corruptione Aristotelis, 18-19; Panzica, "Nicole Oresme à la Faculté des Arts de Paris", 36; Ead., "Albert of Saxony's Questions on Meteorology", 255-257.

\section{Wroctaw, Biblioteka Uniwersytecka, IV Q 27, ff. $1^{r}-163^{r}(\mathrm{Wr})$}

Paper; mm 220 × 150; ff. II +165; 14th century

Date and origin. On f. $165^{\mathrm{v}}$, we find a mark of possession that has subsequently been erased: "Liber Nicolai de scola $†$ artium baccalaurei". The date and provenance of this manuscript are unknown. On the back inside-cover, we read: "Anno millesimo trecentesimo nonagesimo nono obyt serenissima princeps regina 
Hedwigis in Cracovia in die sancti Galli". This note proves that the manuscript circulated at Krakow University. It came into the possession of the Wrocław University Library in 1810.

Codicology. Wooden binding. Traces of pegs on both covers; traces of the central boss on the front cover. A paper guard-leaf, on the verso of which we find a table of contents of the first book of Oresme's Questions on Meteoro$\operatorname{logy}$. At the bottom of this leaf, numbered I on the verso by a modern hand, we find a piece of modern paper, upon which is written: "Aus der Bibliothek des Kollegiatstifts zu Glogau". A second guard-leaf, this one in parchment, has been numbered II on the recto by a modern hand. On the verso of this leaf, we read: "Dominus Petrus Nachancze dedit". The guard-leaves are followed by 165 paper leaves grouped mainly in senions: I $(1-12)^{6+6}$; II $(13-26)^{7+7}$; III $(27-38)^{6+6}$; IV $\left(39^{-50}\right)^{6+6}$; V $\left(5^{1-62}\right)^{6+6}$; VI $\left(63^{-74}\right)^{6+6}$; VII $\left(75^{-86}\right)^{6+6}$; VIII $\left(87^{-98}\right)^{6+6}$; IX $\left(99^{-}\right.$ $110)^{6+6}$; X (111-122) ${ }^{6+6}$; XI $(123-134)^{6+6}$; XII $\left(135^{-146}\right)^{6+6}$; XIII $(147-158)^{6+6}$; XIV $\left(159^{-163}\right)^{(3-1)+3} ; \mathrm{xv}(164-165)^{1+1}$. Signatures on the recto of the following leaves: f. 1 (us), f. 13 (2us), f. 27 (3us), f. 39 (4us), f. 51 (5us), f. 63 (6us), f. 75 ( 7 us), f. 87 (8us), f. 99 (9us), f. 111 (10), f. 123 (XI), f. 135 (XIIUs), f. 147 (XIIIUs), f. 159 (XIIII). Modern foliation in black ink in the upper outer margin.

Content. This manuscript only contains Oresme's Questions on Meteorology, (ff. $1^{\mathrm{r}}-163^{\mathrm{r}}$ ), followed by a table of contents of the four books (ff. $164^{\mathrm{r}}-165^{\mathrm{r}}$ ). Another table of contents, concerning only the first book, can be found on the verso of the first guard-leaf.

The Questions on Meteorology. A rubricated initium by the hand of the copyist ascribes the text to Nicole Oresme: "Hee sunt questiones magistri Orem super libris Metheororum" (f. $1^{r}$ ). This ascription is repeated in the colophons of the third and of the fourth book (see below). The text, which was copied in a single hand in brown ink, is written in a single column of about thirty-five lines per page. The handwriting is regular and easily readable. The incipits of the books and of the questions are written in textualis and framed in red. Short marginal notes referring to the structure of the text, written by the copyist. Rubricated pilcrows; pointing hands (for example on f. $2^{\mathrm{r}}$ ).

Incipit and explicit of the books

I, ff. $1^{\mathrm{r}}-41^{\mathrm{v}}$ : Circa librum Metheororum Aristotelis, peritissimi philosophi, queritur utrum possibile sit de impressionibus habere metroloycis [sic] simul scientiam et opinionem. Et arguitur primo quod non, quia de impressionibus metroloycis non contingit habere scientiam nec opinionem; igitur questio falsa ...X... Propter quod quia plures antiquorum crediderunt gallaxiam esse de natura elementari. Et sic patent questiones primi libri.

II, ff. $41^{\mathrm{v}}-64^{\mathrm{v}}$ : Questio prima circa secundum, secundum distinctionem in principio positam ab Alberto, et est questio ista: utrum locus generationis 
pluvie sit media regio aeris. Et arguitur primo quod non ...X... Ad rationes in oppositum patet in secundo articulo. Explicit secundus liber libri Metheororum. Sequitur tertius.

III, ff. $64^{\mathrm{v}}-144^{\mathrm{v}}$ : Circa tertium, secundum distinctionem illius libri totius in principio positam ab Alberto, sit questio prima: utrum ventus sit exalatio calida et sicca. Et arguitur primo quod non sit exalatio calida ...X... Ad rationem ultimam dico quod non in vanum laborant, ex quo aliam artem ignorant. Hec sunt dicta de questionibus tertii. Expliciunt questiones tertii libri Metheororum reverendi magistri Orem.

IV, ff. $145^{\mathrm{r}}-163^{\mathrm{r}}$ : $\langle\mathrm{C}\rangle$ irca principium istius quarti queritur primo utrum tantum sint quatuor qualitates prime, scilicet caliditas, frigiditas, humiditas et siccitas. Et arguitur quod non, quia quod per superhabundantiam ...X... ratio huius, quia non uritur ab igne, dicimus quod tale animal habitat in igne. Hec de questione. Amen. Expliciunt questiones Metheororum seu Metherorum magistri Orem.

\section{Bibliography}

Catalogues: W. Göber, and J. Klapper, Katalog der Handschriften der ehemaligen Universitätsbibliothek Breslau, ca. 1920-1944 [manuscript catalogue], 19 (IV Q 1-50); Lohr, Latin Aristotle Commentaries, I.2. Medieval Authors M-Z: 35 .

Literature: A.G.E.Th. Henschel, Catalogus codicum Medii Aevi medicorum ac physicorum qui manuscripti in bibliothecis Vratislaviensibus asservantur, Wrocław 1847 (2 vols.), 2: 30; Birkenmajer, Études d'histoire des sciences en Pologne, 193-194; McCluskey, Nicole Oresme on Light, Color and the Rainbow, 95; Panzica, "Commenter les Météorologiques à l'Université de Cracovie", 78, 157.

20 Città del Vaticano, Biblioteca Apostolica Vaticana, Pal. lat. 1045, f. $118^{v}$ Paper; mm 275 $\times 225$; II $+120+$ I; second half of the fourteenth century Date and origin. The codex consists of two parts: the first one (ff. 1-9o) was copied in Prague in the second half of the fourteenth century; the second part (ff. 91-120) was probably copied in Paris in the same period. The manuscript belonged to Marsilius of Inghen, who left a short annotation on f. $120^{v}$.

Content. This manuscript contains Albert of Saxony's Questions on De celo (ff. $1^{\text {ra }}-61^{\text {rb }}$ ), Albert of Saxony's Sophismata (ff. $65^{\text {ra }}-9 \mathrm{9}^{\mathrm{rb}}$ ); John Buridan's Questions on De anima $\left(91^{\mathrm{ra}}-118^{\mathrm{ra}}\right)$ followed by its table of contents; a partial table of contents of the second redaction of Oresme's Questions on Meteorology $\left(118^{\mathrm{v}}\right)$, and a note on the magnets by the hand of Marsilius of Inghen $\left(120^{\mathrm{v}}\right)$.

The table of contents of Oresme's Questions on Meteorology. The table of contents is preceded by the following words, which ascribe the text to Nicole Oresme: "Hii sunt tituli questionum quas format magister Nicolaus Orem super 
librum Metheororum". The table only covers the first two books of Oresme's commentary. As far as the first part of the text is concerned, the table is quite selective and omits questions I.1-2, I.4, I.6-7. Starting with question I.8, the table corresponds to the actual content of Oresme's commentary. The titles of the questions are followed by their answer, in an extremely concise form. In the following I provide a transcription of this table.

I.3 Primum, utrum iste mundus inferior sit contiguus lationibus superioribus ut eius virtus inde gubernetur, et dicit cum Aristotele quod sic.

I.5 Utrum eedem opiniones infinities reiterentur. Dicit cum Aristotele quod sic.

I.8 Utrum motus celi sit causa calefactionis ignis in spera sua et etiam supreme regionis aeris. Dicit cum Philosopho quod sic.

I.9 Utrum lumen sit productivum caloris. Dicit cum Philosopho quod sic.

I.10 Utrum contrarium circumstans suum contrarium fortificet ipsum per anthiparistasim. Dicit cum Philosopho quod sic.

I.11 Utrum media regio aeris sit semper frigida. Dicit cum Philosopho quod sic.

I.12 Utrum omnium impressionum metheorologicarum exalatio et vapor sunt materia. Dicit cum Philosopho quod sic.

I.13 Utrum impressiones ignite que fiunt per inflammationem exalationis fiunt naturaliter in aere. Dicit quod sic.

I.14 Utrum de nocte, serenitate existente, debeant apparere hyatus et voragines et sanguinei colores. Dicit cum Philosopho quod sic.

I.15 Utrum cometa sit de natura celesti vel de natura elementari. Dicit cum Philosopho quod sit de natura elementari.

I.16 Utrum cometa sit exalatio callida [sic] inflamata [sic]. Dicit cum Philosopho quod sic.

I.17 Utrum motus comete sit naturalis vel violentus. Dicit quod sit naturalis.

I.1 8 Utrum comete significent mortem principum, siccitates, ventos et terre motus. Dicit quod sic.

I.19 Utrum galaxia sit de natura elementari vel celesti. Dicit quod sit de natura celesti. Sequitur de secundo libro.

II.1 Utrum locus generationis pluvie sit media regio aeris. Dicit cum Philosopho quod sic.

II.2 Utrum pluvia, nix et pruina sint eiusdem speciei. Dicit cum Philosopho quod sic.

II.3 Utrum grandines magis debeant generari in hyeme et estate quam in vere et autumpno. Dicit cum Philosopho quod magis in vere et autumpno. 
II.4 Utrum aqua calida applicata frigori congelanti citius congeletur quam aqua frigida. Dicit cum Philosopho quod sic.

II.5 Utrum rubedo matutina sit signum pluvie. Dicit quod sic.

II.6 Utrum caligo sit signum future pluvie. Dicit cum Philosopho quod non.

II.7 Utrum aqua naturaliter ascendat ad orificia fontium. Dicit quod non.

II.8 Utrum aque fontium generentur in terra. Dicit cum Philosopho quod sic.

II.9 Utrum mare sit perpetuum vel aliquando fuerit factum. Dicit cum Philosopho quod sic.

II.1O Utrum mare debeat fluere et refluere. Dicit quod sic.

II.1 1 Utrum aqua maris debeat esse salsa. Dicit quod sic.

II.12 Utrum aque puteales debeant esse salse. Dicit quod sic.

\section{Catalogues}

D. Walz, Die historischen und philosophischen Handschriften der Codices Palatini Latini in der Vatikanischen Bibliothek (Cod. Pal. Lat. 921-1078), Wiesbaden 1999 (Kataloge der Universitätsbibliothek Heidelberg, 3), 200-202.

Overview of the Manuscripts

\begin{tabular}{|c|c|c|c|}
\hline Signature & Siglum & Date & Origin \\
\hline Basel, uB, lat. F I 11 & $\mathrm{Ba}$ & 1369 & Prague \\
\hline Basel, uB, lat. F v 2 & $\mathrm{Ba}$ & 1369 & Prague \\
\hline Berlin, sB-PK, lat. fol. 631 & $\mathrm{Be}$ & 1470 & Central Europe \\
\hline Erfurt, $\mathrm{CA}, 2^{\circ} 334$ & $\mathrm{E}$ & 1421 & Göttingen \\
\hline Kassel, LB, $2^{\circ}$ Phys. et hist. nat. 12 & Ka & 1424 & Central Europe \\
\hline Klagenfurt, Bisch. Bibl., XXXI b 5 & $\mathrm{Kl}$ & ca. $1395^{-1405}$ & Central Europe \\
\hline Kraków, BJ, 749 & $\mathrm{Kr}$ & $1360-1370$ & Prague \\
\hline Kraków, BJ, $75^{1}$ & $\mathrm{Kr}_{1}$ & $1360-1370$ & Prague \\
\hline Kraków, BJ, 2095 & $\mathrm{Kr}_{2}$ & 1406 & Prague \\
\hline Kraków, BJ, 2117 & $\mathrm{Kr}_{3}$ & $1444-145^{\circ}$ & Frankfurt (Oder) \\
\hline Leipzig, uB, 1387 & $\mathrm{~L}$ & 1429 & Leipzig \\
\hline München, вs в, Clm 4376 & M & $1365^{-13} 86$ & Prague \\
\hline München, вs в, Clm 17226 & $\mathrm{M}^{1}$ & 1413 & Central Europe \\
\hline Paris, BnF, lat. 15156 & $\mathrm{P}$ & ca. 1369 & Paris \\
\hline St. Gallen, Stibi, Cod. Sang. 839 & $\mathrm{Sg}$ & 1459 & Germany? \\
\hline Uppsala, uB, C 596 & $\mathrm{U}$ & 1424 & Germany? \\
\hline
\end{tabular}


(cont.)

\begin{tabular}{llll}
\hline Signature & Siglum & Date & Origin \\
\hline Wien, ÖNB, Cod. 5453 & Wi & 1370 & Prague \\
Wrocław, BU, IV Q 27 & Wr & 14th C expl. & Central Europe \\
Vaticano, BAV, Pal. lat. 1045 & Va & 14 th & Prague/Paris? \\
\hline
\end{tabular}

\section{Relationships between the Manuscripts: A Twofold Tradition}

The collation clearly shows that the manuscript tradition of the second redaction of Nicole Oresme's Questions on Meteorology is divided into two branches: on the one side family $\alpha$, of which only one member has so far been identified, namely $P$; on the other side family $\beta$, which comprises all other witnesses $(B a$, $B a^{1}, \mathrm{Be}, \mathrm{Ka}, \mathrm{Kl}, \mathrm{Kr}, \mathrm{Kr}^{1}, \mathrm{Kr}^{2}, \mathrm{Kr}^{3}, \mathrm{~L}, \mathrm{M}, \mathrm{M}^{1}, \mathrm{Po}, \mathrm{Sg}, \mathrm{U}, \mathrm{Wi}, \mathrm{Wr}$ ).

I shall discuss the particularities of $P$ as the sole representative of family $\alpha$ later in more detail. For the moment, I will present the common accidents of family $\beta$ and its subfamilies. I consider an accident as typical for one family if it is shared by half of the members of this family +1 . If the accident is also shared by other manuscripts, I do not consider it as typical for this family. The following lists present the results of a sample portion of the collation, namely the beginning of question I.1 (lines $1-5 \mathrm{O}$ in our edition) and of question II.2 (lines 1-44 in our edition). The text before the brackets is the text of $P$.

\section{Additions of family $\beta$}

1) I.1, 1 non] quia add. $\mathrm{Ba} B a^{1} \mathrm{Be} K a \mathrm{Kl} \mathrm{Kr} K r^{1} \mathrm{Kr}^{2} \mathrm{Kr}^{3} \mathrm{LM}$ Po Sg UWi Wr

2) I.1, 3 posteriorum] sed add. Ba Ba ${ }^{1} \mathrm{Be} \mathrm{Ka} \mathrm{Kl} \mathrm{Kr}^{1} \mathrm{Kr}^{2} \mathrm{Kr}^{3} \mathrm{~L} M$ Po Wi Sg UWr

3) I.1, 5 scientia] illa $a d d$. $B a^{1} B e ~ K a ~ K r^{1} K^{2} K^{3} L M P o ~ S g ~ U W i$

4) I.1, 6 formidine] ad oppositum add. Ba ${ }^{1} \mathrm{Be} \mathrm{Ka} \mathrm{Kl} \mathrm{Kr} \mathrm{Kr}{ }^{1} \mathrm{Kr}^{2} \mathrm{Kr}^{3} \mathrm{LM} \mathrm{Po} \mathrm{Sg}$ $U W i W r$

5) I.1, 6 formidine] ad oppositum add. $\mathrm{Ba} \mathrm{Ba}{ }^{1} \mathrm{Ka} \mathrm{Kr} \mathrm{Kr}^{1} \mathrm{Kr}^{2} \mathrm{Kr}^{3} \mathrm{Po} U \mathrm{Wi}$

6) I.1, 6 sicut] prius add. Ba Ba $a^{1} \mathrm{Be} \mathrm{Ka} \mathrm{Kl} \mathrm{Kr} \mathrm{Kr}^{1} \mathrm{Kr}^{2} \mathrm{Kr}^{3} \mathrm{MPo} \mathrm{Sg} U W i \mathrm{Wr}$

7) I.1, 6 non] est add. $\mathrm{Ba} \mathrm{Ba}{ }^{1} \mathrm{Ka} \mathrm{Kr}^{1} \mathrm{Kr}^{2} \mathrm{Kl} U \mathrm{Wi} \mathrm{Wr}$

8) I.1, 6 subiectum] istius add. $B a^{1} K l K r_{K r}{ }^{1} K^{2} M$ Po $S g U W i W r$

9) II.1, 1 nec aqua] nec pluvia nec aqua $\left.B a^{1} K a K^{1} L M P o M^{1} W i W r\right]$ nec aqua nec pluvia $\mathrm{Ba} \mathrm{Kl} \mathrm{K}^{1} \mathrm{Kr}^{2} \mathrm{Kr}^{3} \mathrm{Sg} U$

10) II.1, 3 regionem] aeris add. Ba Be Ka Kl Kr $\mathrm{Kr}^{1} \mathrm{Kr}^{2} \mathrm{~L} M \mathrm{M}^{1} \mathrm{Po} S g \mathrm{UWr}$

11) II.1, 3 illius] in add. Ba Be Ka L Kl Kr $\mathrm{Kr}^{1} \mathrm{Kr}^{2} \mathrm{Kr}^{3} \mathrm{USg} \mathrm{Wi} \mathrm{Wr}$ 
12) II.1, 4 regionem] aeris add. Be Ka LM Kl Kr $\mathrm{Kr}^{2} K r^{3} M^{1} \mathrm{Po} S g U W i W r$

13) II.1, 7 probatur] quia add. Be $K l K r^{3} L M^{1} \mathrm{Po} S g U K W r$

14) II.1, 7 vapores] sufficientes add. Ba ${ }^{1} \mathrm{Be} K a \mathrm{Kl} L \mathrm{M} \mathrm{Kr} K r^{1} \mathrm{Kr}^{2} \mathrm{Kr}^{3} \mathrm{M}^{1} \mathrm{Po} \mathrm{Sg} U$ Wi Wr

15) II.1, 7 regionis] aer $a d d$. $\left.B a K a K l K r^{3} L W i W r\right]$ aeris $\left.a d d . M\right]$ aeris aer $a d d$. $B a^{1} B e K r r^{1} K^{2} M^{1}$ Po SgW

16) II.1, 7 sufficientes] ibi add. Ba Ba $a^{1} B e K a L M K r K r^{1} K r^{2} M^{1} P o S g U W i W r$

Omissions of family $\beta$

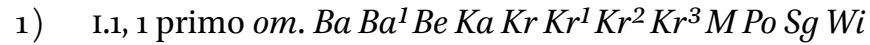

2) I.1, 1 etiam om. Ba Ba ${ }^{1} B e ~ K a K l K r^{1} K r^{2} K r^{3} M$ Po Sg UWi Wr

3) I.1, 2 de se om. Ba Ba ${ }^{1} B$ e Ka KlMPo Sg Kr Kr $\mathrm{Kr}^{2} K r^{3} W i W r$

4) I.1, 2 in om. Ba Ba ${ }^{1} \mathrm{Be} K a K l K r^{1} K r^{2} K^{3} L M S g U W i W r$

5) I.1, 3 et om. Ba Ba ${ }^{1} B e K a K l K r^{1} K r^{2} K^{3} L M P o S g U W i W r$

6) I.1, 6 qui tradiderunt nobis scientiam de impressionibus metheorologicis et sic patet auctoritatibus quod de impressionibus metheorologicis potest

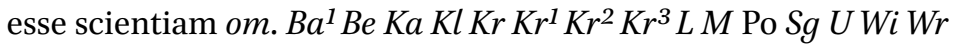

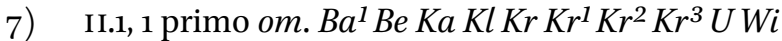

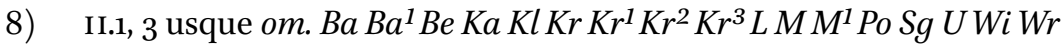

9) II.1, 4 in vallibus om. Ba Ba ${ }^{1} \mathrm{Be} \mathrm{Ka} \mathrm{Kl} \mathrm{Kr} \mathrm{Kr}{ }^{1} \mathrm{Kr}^{2} \mathrm{Kr}^{3} \mathrm{~L} M M^{1} \mathrm{Po} S g U W i W r$

10) II.1, 4 nubes et om. Ba ${ }^{1} \mathrm{Be} K a \mathrm{Kl} \mathrm{Kr} \mathrm{Kr}{ }^{1} \mathrm{Kr}^{2} \mathrm{Kr}^{3} \mathrm{~L} M M^{1} \mathrm{Po} S g \mathrm{UWi} W r$

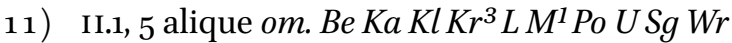

12) II.1, 6 videndum est om. Ba Ba ${ }^{1}$ Be Ka Kl Kr Kr $\mathrm{Kr}^{2} \mathrm{Kr}^{3} \mathrm{LM} \mathrm{M}^{1} \mathrm{Sg}$ Po UWi

13) II.1, 6 videndum est ${ }^{2}$ om. Ba Ba ${ }^{1} B e K a K l K r K r^{1} K r^{2} K r^{3} L M M^{1} P o S g U W i$ $W r$

14) II.1, 6 videndum est om. Ba Ba ${ }^{1} B$ e Ka Kl Kr Kr ${ }^{1} r^{2} K^{3} L M M^{1} P o S g U W i$ $W r$

15) II.1, 7 vel om. Ba Ba ${ }^{1}$ Be Ka Kl Kr Kr ${ }^{1} K^{2} K r^{3} L M M^{1} P o S g U W i W r$

16) II.1, 7 si om. Ba Ba ${ }^{1} \mathrm{Be} K a \mathrm{Kl} \mathrm{Kr} \mathrm{Kr}{ }^{1} \mathrm{Kr}^{2} \mathrm{Kr}^{3} \mathrm{LM} M^{1} \mathrm{Po} S g U W i W r$

Variants of family $\beta$

1) I.1, 1 impressiones autem metheorologice] sed impressiones metheorologice $B a B a^{1} K r K r^{1} K r^{2} L U W i$

2) I.1, 3 nota est] tenet $B e K a K l K r L M P o S g U W i W r$ ] patet $B a B a^{1} K^{1} K^{2}$

3) I.1, 3 quod non est verum non potest sciri] nichil contingit sciri nisi verum $\mathrm{Ba} \mathrm{Ba}{ }^{1}$ Be Ka Kl L Kr ${ }^{1} \mathrm{Kr}^{2} \mathrm{Kr}^{3} \mathrm{MPo} S g \mathrm{U} W \mathrm{~W} \mathrm{rr}^{60}$

6o We can consider this variant to be shared by all the members of family $\beta$ : in fact, the only witness that transmits a different text, $K r$, reads: "nichil convenit sciri nisi verum", which 
4) I.1, 4 quia] ex eo quod $\left.B a K r K r^{1} K r^{3} L M U W i W r\right]$ eo quod $\left.K r^{2}\right]$ ex eo quia $K a K l]$ de eo quod $B a^{1}$

5) I.1, 4 de illo de quo] de illis de quibus $B a B a^{1} B e K r K r^{1} K r^{2} L M S g U W i W r$ ] ex hiis de quibus $K l K^{3}$

6) I.1, 4 corruptibili] corruptibilibus $B a \mathrm{Ba}^{1} \mathrm{Be} K a \mathrm{Kl} K r^{1} \mathrm{Kr}^{2} \mathrm{Kr}^{3} \mathrm{LM} \mathrm{Po} S g U$ Wi $W r$

7) I.1, 4 ut videtur non possunt] $B a B a^{1} K r K r^{1} K r^{2} L M W i W r$ ] non videntur posse $K l$

8) I.1, 5 fiunt] sunt $B a B a^{1} K l K r^{1} K r^{2} W i W r$

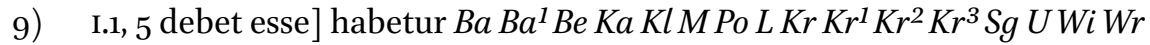

10) I.1, 5 in littera] in primo illius/huius libri $\mathrm{Be} \mathrm{Ka} \mathrm{Kr^{3 }} \mathrm{LMPo} \mathrm{SgU}$ ] in primo huius $\mathrm{Ba} \mathrm{Kl} \mathrm{Kr}{ }^{1} \mathrm{Kr}^{2} \mathrm{Wi} W r$

11) I.1, 5 dicit enim] ubi dicit $\left.B a B a^{1} B e K a K l K r^{1} K r^{2} K r^{3} M P o S g U W i W r\right]$ ut dicit $L$

12) I.1, 5 accidunt] contingunt $\mathrm{Ba} \mathrm{Ba}{ }^{1} \mathrm{Be} \mathrm{Ka} \mathrm{Kl} \mathrm{Kr}^{1} \mathrm{Kr}^{2} \mathrm{Kr}^{3} \mathrm{~L} M \mathrm{Po} S g \mathrm{UWi} W r$

13) I.1, 6 in oppositum est aristoteles et albertus et alii] oppositum vult aristoteles albertus et alii $B a B a^{1} K l K r^{1} K r^{2} L M S g W i W r$ ] oppositum vult albertus et alii $B e$

14) I.1, 6 ipsis] impressionibus $B a^{1} B e K r K r^{1} K r^{2} M S g W i$

15) I.1, 6 quia] nam $B a B a^{1} B e K a K l K r^{1} K r^{2} K r^{3} L M P o S g U W i W r$

16) I.1, 6 quia $^{2}$ ] nam $B a B a^{1} B e K a K l K r^{1} K r^{2} K r^{3} L M P o S g U W i W r$

17) I.1, 6 quia de eadem re possibile est] immo possibile est de eadem re $B a$ $B a^{1} B e K l K r^{1} K^{2} K^{3} L M P o S g U W i W r$

18) I.1, 6 et iret] ambulans $\left.B a B a^{1} K l K r K r^{1} K r^{2} W i W r\right]$ et ambularet $B e L M S g$ ] ambulat $K r^{3}$ ] ambulet $K a U$

19) I.1, 6 ista] tunc hac $\left.B a B a^{1} B e K a K l K r^{1} K r^{2} K r^{3} S g U W i W r\right]$ hac $L M$

20) I.1, 6 demonstrando patrem tuum] et sic $B a B a^{1} B e K a K l L M P o K r^{1} K^{2} K^{3}$ $\mathrm{Sg} U \mathrm{Wi} \mathrm{Wr}$

21) I.1, 6 est] esset $\mathrm{Ba} \mathrm{Be} \mathrm{Ka} \mathrm{Kr} \mathrm{Kr}{ }^{3} \mathrm{~L}$ Po USg Wi

22) I.1, 6 ipse enim est] quia pater tuus est $\mathrm{Ba} \mathrm{Ba} a^{1} \mathrm{Be} K a \mathrm{Kl} \mathrm{Kr} K r^{1} \mathrm{Kr}^{2} \mathrm{Kr}^{3} \mathrm{~L}$ Po $S g U W i W r$ (quia pater est $M$ )

23) I.1, 6 istius propositionis] talis conclusionis $\mathrm{Ba} \mathrm{Ba}^{1} \mathrm{Ka} \mathrm{Kl} \mathrm{Kr}$ (ante correctionem) $\left.K r^{1} L M S g U W i W r\right]$ istius conclusionis $\left.K r^{2} K r^{3}\right]$ illius conclusionis $\mathrm{Be}$

24) I.1, 6 similiter eandem conclusionem quam sor opinatur plato potest scire] similiter eandem conclusionem quam sor scit plato potest opinari

is nothing other than a somewhat corrupted form of the variant shared by family $\beta$ due to a faulty reading of the abbreviation used for the word "contingit". 
$\mathrm{Ba} \mathrm{Ba} a^{1} \mathrm{Be} \mathrm{Ka} \mathrm{Kr}{ }^{1} \mathrm{Kr}^{2} \mathrm{Kr}^{3} \mathrm{~L}$ M Po Sg U Wi] similiter eandem conclusionem quam sor scit plato potest opinare $\mathrm{Wr} K l]$ similiter eandem conclusionem quam scit sor plato potest opinari $\mathrm{Kr}$

25) I.1, 6 potest esse] esset $\left.B a \mathrm{Ba}^{1} \mathrm{Be} \mathrm{Ka} \mathrm{Kl} \mathrm{Kr} \mathrm{Kr}^{1} \mathrm{Kr}^{2} \mathrm{~L} M S g \mathrm{UWi} W r\right]$ sit $\mathrm{Kr}^{3}$

26) II.., 2 videtur tenere] tenet $\left.B a^{1} K a K l K r^{1} K r^{3} M M^{1} P o U W i W r\right]$ nota est L] est nota $B e S g$ ] patet $B a K^{1} K^{2}$

27) II.1, 2 idem non est] idem non videtur esse $B a \mathrm{Ba}^{1} \mathrm{Be} \mathrm{Kl} \mathrm{Kr} \mathrm{Kr}^{1} \mathrm{Kr}^{2} \mathrm{Kr}^{3} \mathrm{M}^{1}$ Po $U S g W i W r]$ non videtur esse idem $M$

28) II..1, 2 fulgura] fulmina $\mathrm{Ba} \mathrm{Ba} a^{1} \mathrm{Be} \mathrm{Ka} \mathrm{Kr}^{1} \mathrm{Kr}^{2} \mathrm{Kr}^{3} \mathrm{~L} M M^{1} \mathrm{Po} S g \mathrm{U} W \mathrm{Wr}$ ] ultima $K l$

29) II.1, 2 per] propter $B a B a^{1} K a K r K r^{1} K r^{2} K r^{3} L M^{1} P o S g W i W r$

30) II.1, 3 inde] deinde $B a \mathrm{Ba}^{1} \mathrm{Be} \mathrm{Ka} \mathrm{Kr} \mathrm{Kr}{ }^{1} \mathrm{Kr}^{2} \mathrm{Kr}^{3} \mathrm{~L} M \mathrm{Po} \mathrm{Sg} U W i$

31) II.1, 3 converteretur in aquam] sequeretur pluvia $\mathrm{Be} \mathrm{Ka} \mathrm{Kl} \mathrm{Kr}{ }^{3} \mathrm{LPo} \mathrm{Sg} \mathrm{Wr}$ ] sequitur pluvia $B a K r K r^{1} K r^{2} M M^{1} U W i$

$3^{2}$ ) II.1, 3 deberet fieri] fieret $B a B a^{1} B e ~ K a ~ K l ~ K r ~ K r^{1} K^{2} K^{3} L M M^{1} P o ~ U S g W i$ Wr

33) II.1, 3 ita] sic $B a B a^{1} B e ~ K a ~ K l ~ K r ~ K r^{1} K^{2} K^{3} L M M^{1} P o ~ U W r$ om. $S g$

34) II.., 4 existens] stans $\left.B a^{1} K a K l K r^{1} K r^{2} K r^{3} M M^{1} P o U W i W r\right]$ steteat $L$ ] stetit $\mathrm{Ba}$ ] steterat $\mathrm{Be} \mathrm{Sg}$ om. $\mathrm{K}$

35) II.1, 4 montes enim illi non sunt] quia montes non sunt $\mathrm{BaBa}{ }^{1} \mathrm{Be} \mathrm{Ka} \mathrm{Kr} \mathrm{Kr}{ }^{1}$ $\left.\mathrm{Kr}^{2} \mathrm{Kr}^{3} \mathrm{Po} S g \mathrm{U} W \mathrm{i}\right]$ quia sunt $\mathrm{Kl} W r$ ] quia montes sunt $M M^{1}$ ] quia aliqui montes sunt $L$

36) II.1, 4 ita] tam Ba Be Ka Kl Kr Kr ${ }^{1} \mathrm{LMSg}$ Wi Wr om. $\mathrm{Kr}^{2}$

37) II.1, 4 attingerent] attingunt $\left.B a^{1} \mathrm{Ka} \mathrm{Kl} \mathrm{Kr}{ }^{1} \mathrm{Kr}^{2} \mathrm{M} M^{1} \mathrm{Po} \mathrm{Wi} W r\right]$ attingant $\mathrm{Ba}$ K

38) II.1, 5 in oppositum est] oppositum dicit $\mathrm{Ba} \mathrm{Ba}{ }^{1} \mathrm{Be} \mathrm{Kl} \mathrm{Kr} \mathrm{Kr}^{1} \mathrm{Kr}^{2} \mathrm{LSg} \mathrm{WiWr}$ (in oppositum est $U$ )

39) II.1, 6 exponende] ponende $\mathrm{Be} \mathrm{Ka} \mathrm{Kl} \mathrm{Kr}^{3} \mathrm{LM} M^{1} \mathrm{Po} S g U W r$

40) II.1, 6 pluvie] pluviarum $\mathrm{Ba}^{1} \mathrm{Be} \mathrm{Ka} \mathrm{Kr}{ }^{1} \mathrm{Kr}^{2} \mathrm{Kr}^{3} L M M^{1} \mathrm{Po} S g \mathrm{UWi} \mathrm{Wr}$ (pluvie $K l)$

41) II.1, 6 pluviarum quoad quantitatem] guttarum ipsius pluvie $\mathrm{Ka} \mathrm{Kl} \mathrm{Kr}^{3} \mathrm{M}$ $M^{1} U P o W r$ ] guttarum $B e S g$ ] guttarum earum $L$ (de quantitate pluviarum $\left.\mathrm{Ba} \mathrm{Ba}{ }^{1} \mathrm{Kr} K r^{1} \mathrm{Kr}^{2} \mathrm{Wi}\right)$

42) II.1, 7 declaratur] probatur $\mathrm{Ba} \mathrm{Ba} a^{1} \mathrm{Be} \mathrm{Ka} \mathrm{Kl} \mathrm{Kr} \mathrm{Kr}^{1} \mathrm{Kr}^{2} \mathrm{Kr}^{3} \mathrm{~L} \mathrm{M}^{1} \mathrm{Po} \mathrm{Sg} \mathrm{UWi}$ $W r($ M lect. dub.)

43) II.1, 7 elevatum in nubem et convertere in aquam] et convertere in nubem et sic sequitur pluvia $\mathrm{Ba} \mathrm{Ba}{ }^{1} \mathrm{Kl} \mathrm{Kr}{ }^{1} \mathrm{Kr}^{3} \mathrm{LPo} \mathrm{Wi}$ ] et convertere in nubem et ut sic sequitur pluvia $K r$ ] et convertitur in nubem et sic sequitur pluvia $\left.K r^{2}\right]$ et convertere in nubem et sequitur pluvia $K a M M^{1} U$ ] et vertere in pluvias et sequitur inde pluvia $B e S g$ 
44) II.1, 7 ecce causas sufficientes in media regione aeris] ergo sunt in media regione aeris cause sufficientes $B a \mathrm{Ba}^{1} \mathrm{Kl} K r \mathrm{MWi}$ ] igitur in media regione aeris sunt cause sufficientes $B e K r K r^{1} K r^{2} S g$ ] ergo in media regione aeris cause sufficientes $W r$ ] ideo sunt cause sufficientes in media regione aeris $K a K r^{3} M M^{1} P o U$

45) II.1, 7 et fieret] quod fieret $\left.B a B a^{1} K a K l K r K r^{1} K r^{2} K r^{3} L M M^{1} P o U W i W r\right]$ quod fiat $\mathrm{Be} S g$

46) II.1, 7 reliquum] alterum $B a^{1} K a K l K r K r^{1} K r^{3} L M M^{1} P o U W i W r$ ] aliud $B a$ $K r^{2}$

Inversions and transpositions of family $\beta$

1) I.1, 6 aliquis assentit] assentit aliquis $B a B a^{1} B e ~ K a K l M K r K r^{1} K^{2} K^{3} M$ $S g U W i W r$ (consentit aliquis Po)

2) I.1, 6 super manus et pedes] super pedes et manus $\mathrm{Ba} \mathrm{Ba} a^{1} \mathrm{Ka} \mathrm{Kl} \mathrm{Kr} \mathrm{Kr}{ }^{1}$ $\left.K r^{3} L P o S g U W i W r\right]$ super pedes et super manus $M$ ] per pedes et manus Be

3) I.1, 6 a te opinata] opinate a te $B a B a^{1} B e K a K l K r K r^{1} K r^{2} K r^{3} L M P o S g U$ $W i W r$

Question I.5 provides a good example of the differences between $P$ and manuscripts of family $\beta$. In the following table, I present an example taken from the solution of this question, transcribed from manuscript $P$ and from manuscript $K l$, chosen as representative for family $\beta$ :

Quantum ad tertium, sit ista conclusio: huiusmodi variatio fit effective a corpore celesti tamquam ab agente universali et generali. Patet ex precedentibus duabus questionibus, nam ista inferiora reguntur ab illis superioribus, sicut prius dicebatur; ergo, causa variationis in istis inferioribus est influentia celestis. Istud etiam patet per astrologos, ponentes quod aliquando fiunt alique magne coniunctiones que sunt cause inceptionis quarundam sectarum et opinionum que diu durant, si non sint mediocres; si autem sint parve, tunc sunt cause inceptionis sectarum et.
Ad tertium sit conclusio hec: quod huiusmodi variatio opinionum fit effective a corpore celesti tamquam a causa effective universali et generali. Patet ex duabus questionibus precedentibus, nam inferiora reguntur a superioribus, sicut prius dicebatur; ergo causa variationis in istis inferioribus est influentia celestis. Hoc etiam patet per astrologos, volentes quod aliquando fiunt alique magne coniunctiones que sunt cause inceptionis quarundam sectarum et quarundam opinionum, et quedam coniunctiones, si sunt magne, tunc sunt cause inceptionis quarundam 
(cont.)

Text of $P 233^{\mathrm{r}}$

opinionum que per modicum tempus durant $[\ldots]$

Similiter variatio opinionum in aliquo regno potest fieri per guerras in illo regno; unde, cum sunt guerre in aliquo regno, homines non possunt insistere studio, sed oportet eos insistere aliis, et sic potest accidere variatio opinionum in regno. Etiam potest fieri propter sterilitatem; unde, acquisitis necessariis, Antiqui inceperunt philosophari.

Similiter potest accidere variatio opinionum propter variationem complexionum et inclinationum hominum; unde aliquando homines magis inclinantur ad praxim quam ad speculandum, et hoc aliquando accidit propter malitiam hominum. Cum enim speculativi non honorentur, qui bene insisterent speculationibus ponunt se ad practicam, sicut tempore hodierno experimur. Plures enim se dant legibus quam artibus, et isto modo opiniones variantur in ignorantiam et non in opinionem contrariam.

Quantum ad quintum, potest dici quod causa finalis huiusmodi variationis et reiterationis opinionum est decor universi, unde propter talem variationem, universum est pulchrius. Unde propter aliquam rem in se turpem una tota multitudo potest fieri pulchrior, sicut potest
Text of family $\beta(K l)$

sectarum et quarundam opnionum que diu durant; si autem tales coniunctiones sunt mediocres, tunc essent cause inceptionis opinionum que mediocriter durant, sed si sunt parve, tunc etiam cause talis durationis sunt parve. Hoc de tertio [...].

Etiam variatio opinionum in aliqua regione potest fieri per guerras, nam in regionibus homines propter guerras non coexistunt studio. Potest etiam fieri propter sterilitatem, quia, habitis necessariis, antiqui ceperunt phylosophari, sicut recitat Aristoteles in prohemio Metaphysice, ubi dicit quod antiqui sacerdotes in Egipto iam habentes omnia vite necessaria invenerunt scientias speculativas.

Similiter, etiam fieri potest variatio opinionum propter naturalem inclinationem hominum ad opiniones, unde aliqui homines magis inclinantur ad praxim, id est ad scientias practicas, quam ad speculandum, et hoc aliquando fit propter malitiam hominum. Cum nunc viri speculativi non honorantur, ponunt se ad leges, et in isto fit variatio opinionum in ignorantiam et non in scientiam, ut si artiste student leges. Hoc de quarto.

Quantum ad quintum, potest dici quod causa finalis huiusmodi variationis et reiterationis opinionum est decor universi, unde propter talem variationem opinionum universum est pulchrius. Nam etiam propter aliquam rem in se turpem una tota multitudo potest fieri pulchrior, sicut 
(cont.)

Text of $P$ 233

apparere picturis. Alia causa similiter huiusmodi variationis potest esse exercitium et intellectus hominum delectatio, quia delectatur in novitatibus et variationibus.

Ad rationes. Ad primam dico quod secundum Philosophum conceditur quod mundus est eternus, et isto sumpto infinities eedem opiniones reiterantur; cuius causa dicta est in questione, quia infinities consimiles fiunt coniunctiones planetarum que aliquando erant, que sunt causa huiusmodi variationis et reiterationis opinionum.
Text of family $\beta(K l)$

patet in picturis, ut si aliquis paries est depictus albo colore et viridi et nigro, qui color tamen in se turpis est, et sic de alijs coloribus, tamen ex hoc ille color redderetur pulchrior. Secundo dico quod causa finalis istius variationis est exercitium et delectatio intellectui humani, nam intellectus humanus delectatur in varietatibus et novitatibus. Hoc de articulo quinto.

Ad primam dico: si conceditur secundum Aristotelem quod mundus esset eternus, tunc eedem opiniones infinities reiterentur, et huiusmodi causa dicta est.

Manuscripts of family $\beta$ alter the arguments contra of question I.11:

Text of $P$ 241 ${ }^{\mathrm{v}}$

Et arguitur primo quod non: semper media regio aeris est calida; igitur non frigida. Consequentia tenet; antecedens patet ex eo quod aer per se et naturaliter est calidus et humidus.

Secundo: si semper media regio aeris esset frigida, vel ergo illa frigiditas inesset sibi naturaliter, vel violente. Non potest dici quod naturaliter, cum contrarium frigiditatis insit sibi naturaliter, puta caliditas; nec potest dici quod violente, quia tunc

\section{Text of family $\beta$}

Et arguitur primo quod non, quia semper media regio aeris est calida; ergo non frigida. Consequentia tenet et antecedens patet ex eo quod aer per se et naturaliter est calidus et humidus.

Secundo: si semper media regio aeris esset frigida, sequeretur quod esset multum densa, sed hoc est falsum. Consequentia tenet ex eo quod frigus est causa condensationis. Falsitas consequentis patet, quia tunc nos impediret ne videmus celum et 
(cont.)

Text of $P$ 241

non semper media regio aeris esset frigida, cum nullum violentum semper duret.

Tertio: si sic, sequeretur quod media regio aeris sit semper densa; sed hoc est falsum. Consequentia tenet ex quo frigiditas est causa condensationis. Falsitas consequentis patet, nam tunc impediret ne videremus celum et astra, nam propter eius densitatem species visibiles celi et etiam astrorum non possent multiplicari usque ad visum nostrum.

Quarto sequeretur quod aer qui est in media regione aeris esset gravior quam aer qui est hic inferius. Hoc est falsum. Consequentia tenet ex eo quod frigida minus frigidis sunt graviora; aer autem hic inferius esset minus frigidus aere existente in media regione, si semper media regio aeris esset frigida. Falsitas consequentis patet, quia tunc aer qui est in media regione descenderet et aer qui est hic inferius ascenderet, cum ordo gravium et levium sit graviora esse sub levioribus et leviora esse super graviora.

Quinto: si sic, sequeretur quod in media regione non generantur impressiones in aere; sed hoc est falsum. Consequentia tenet propter nimiam frigiditatem medie regionis ipsius aeris. Falsitas consequentis patet, nam ibi generantur corruscationes

\section{Text of family $\beta$}

astra, nam propter eius densitatem species visibiles celi et species astrorum non possent multiplicari usque ad visum nostrum.

Tertio: si sic, sequeretur quod aer qui est in media regione aeris esset gravior aere qui est hic inferius. Consequentia tenet ex eo quod magis frigida minus frigidis sunt graviora: aer autem hic inferius est minus frigidus aere existente in media regione aeris. Falsitas consequentis patet, quia tunc aer ille qui est in media regione aeris descenderet et aer inferius ascenderet, cum ordo gravium et levium sit graviora esse sub levioribus et leviora super graviora.

Quarto: si sic, sequitur quod in media regione aeris non generarentur impressiones ignee; sed hoc est falsum. Et consequentia tenet propter nimiam frigiditatem aeris. Falsitas consequentis patet, quia ibi generantur corruscationes et fulgura; illa autem sunt impressiones ignee.

Quinto: si semper media regio aeris esset frigida, vel ergo ista frigiditas inesset sibi naturaliter vel violente. Non potest dici quod naturaliter, quia tunc contrarium inesset sibi naturaliter, puta caliditas. Nec etiam potest dici quod insit sibi violente, 
(cont.)

Text of $P$ 241

et fulgura. Ista autem sunt impressiones ignee.
Text of family $\beta$

quia tunc non semper media regio aeris esset frigida, cum nullum violentum semper duret.

The first sentence of the second argument in manuscripts of family $\beta$ is identical to the corresponding argument in $P$ : afterwards, manuscripts of family $\beta$ mistakenly switch to the third argument in $P$. The content of the second argument in $P$ can be found in the fifth argument of family $\beta$. Moving the second argument to the fifth place creates a difference in the numbering of the arguments which persists until the sixth argument. We find the same difference in the answer to the arguments contra.

The same principle applies to the arguments contra in question I.15. In this case, the order of arguments 5 and 6 is inverted and argument 4 is formulated slightly differently in $P$ and in the manuscripts of family $\beta$. However, as in the other cases, this modification does not affect the content of the text:

\section{Text of $P$}

Quarto ad idem rationibus Senece, nam, si esset de alia natura quam de natura celi, tunc fieret in aere, sicut alie impressiones; sed quecumque impressiones fiunt in aere sunt parve durationis, sicut videmus de nubibus et consimilibus; sed comete non sunt parve durationis, immo magne; igitur etc.

Quinto: impressiones que fiunt in aere non durant nec manent sub eodem astro nec moventur ad motum illius astri, et hoc si fiunt per inflammationem; sed visum est quod cometa movebatur ad modum astri.

\section{Text of family $\beta$}

Quarto confirmatur rationibus Senece, nam, si esset de alia natura quam de natura celi, tunc tales impressiones non diu durarent, et hoc si fieret in aere; sed comete diu durant.

Quinto: comete sunt magne significationis et significant aliquos effectus futuros qui non statim eveniunt; sed impressiones alie non significant aliquos effectus futuros, cum illi cito eveniunt, sicut patet de rubedine matutina ad quam statim sequitur pluvia, ex quo videtur quod 
(cont.)

Text of $P$

Sexto: comete sunt magne significationis et significant aliquos effectus futuros qui non statim eveniunt; sed impressiones alie, si significant aliquos effectus proprios, illi statim eveniunt, sicut patet de rubedine matutina, postquam statim videtur sequi pluvia.
Text of family $\beta$

cometa non sit de natura elementari, sed de natura celi.

Sexto: impressiones que fiunt in aere non diu manent nec moventur sub aliquo astro erratico nec ad motum istius astri, et hoc si fiunt per inflammationem; sed visum est quod cometa movebatur ad motum astri, ex quo sequitur quod non est de natura elementari de qua sunt alie impressiones.

In the second article of question I.14, manuscripts of family $\beta$ omit a long passage:

\section{Text of $P 246^{v}$}

Quantum ad secundum, sit prima suppositio: quando aliqua duo equaliter distant a visu, quorum unum est coloratum vel saltem apparens sub colore magis claro, reliquum vero sub colore minus claro, tunc istud quod apparet sub colore clariori apparet esse propinquius quam istud quod est coloratum colore minus claro. Et istud sciunt pictores: partem enim que debet apparere supereminere colorant colore magis claro et illam que debet apparere densa colore minus claro, sicut colore nigro vel alio tendente ad nigredinem. Et propter istam causam potest contingere quod aliqua superficies plana potest apparere concava vel convexa.

Si enim continue versus medium coloretur colore claro et versus extremum colore

\section{Text of family $\beta$}

Quantum ad secundum, sit prima suppositio: quando aliqua duo equaliter distant a visu quorum unum est coloratum vel saltem apparens sub colore magis claro, reliquum vero sub colore minus claro, tunc illud quod apparet sub colore clariori apparet esse propinquius quam istud quod est magis coloratum. Et hoc bene sciunt pictores: quando enim volunt aliquam partem facere apparere magis prope, tunc colorant ipsam colorem magis claro quam illam partem quam volunt apparere minus. Et propter istam causam potest contingere quod aliqua superficies plana potest apparere concava et profunda. 
(cont.)

Text of $P 246^{v}$

Text of family $\beta$

obscuro, iudicaretur convexa, quia partes medie apparerent propinquiores, quia essent colorate colore clariori. Si autem partes versus medium alicuius superficiei plane essent colorate colore obscuro et versus extremum colore claro, tunc illa superficies apparet concava, quamvis esset plana, quia partes extreme apparent propinquiores quam partes medie; nam essent colorate colore clariori. Sic similiter superficies convexa posset apparere plana, sicut si partes magis versus nos essent colorate colore obscuro et remotiores a nobis colore claro, tunc posset fieri recompensatio claritatis et distantie.

Secunda suppositio: cum lux vel album videtur per nigrum, apparet rubeum. Ista suppositio patet cum videmus Solem per fumum, et propter hoc ignis etiam in carbone apparet coloris rubei: carbo enim est nigri coloris; ignis autem est lucidus.

Secunda suppositio: cum lux vel album videtur per nigrum, tunc apparet rubeum. Ista suppositio patet, quia, cum Solem videmus per fumum, tunc apparet nobis rubeus, et propter hoc etiam ignis in carbone apparet coloris rubei: carbo enim est nigri coloris; ignis autem est lucidus.

All these examples confirm that the manuscript tradition of the second redaction of Oresme's Questions on Meteorology is divided in two branches: on the one side, an isolated manuscript, namely $P$; on the other side, all other copies.

\section{Manuscript $\mathbf{P}$}

Birkenmajer - who, as we have already seen in the introduction, did not know of manuscript $P$-noticed that all the manuscripts of the second redaction of Oresme's Questions on Meteorology he had identified could be related to Central Europe. According to him, "the father of all German copies" did not transmit the original text of Oresme's commentary, but a reworking of it by an anonym- 
ous Prague master. ${ }^{61}$ McCluskey, for his part, mentioned other arguments in favour of Birkenmajer's thesis. He pointed out that seven witnesses of Oresme's Questions - including some of the oldest ones-came from the University of Prague. There bachelors and masters of the Arts Faculty commonly based their lectures on the commentaries of famous masters from Paris and Oxford. ${ }^{62}$ The discovery of a Parisian manuscript provides possible confirmation of Birkenmajer's assumption, as this codex transmits a slightly different text than the other witnesses of Oresme's Questions.

Given the differences between manuscript $P$ and all other copies, one might consider it to be corrupted, but following a complete collation of the text, it seems to me that in the majority of cases where $P$ and manuscripts of family $\beta$ disagree, it is $P$ that provides the better variants. In what follows, I shall give some examples to demonstrate this.

In question I.2, Oresme states that nature is ordered. To corroborate this principle, manuscript $P$ refers to the third book of Aristotle's De celo and to the eighth book of Aristotle's Physics: "natura non est inordinata. Tertio enim Celi et octavo Physicorum dicitur: 'nichil est inordinatum eorum que secundum naturam fiunt'”. The literal quotation can indeed be found in the Latin translation of

61 Birkenmajer, Études d'histoire des sciences en Pologne, 239.

62 This practice is mentioned by the statutes of the University. The Liber decanorum of the Prague Arts Faculty contains a decision, dated 1367 , which regulates the practice of the pronuntiatio. See Statuta et Acta rectorum Universitatis Carolinae Pragensis: 1360-1614, eds. F. Šmahel and G. Silagi, Prague 2018 (Documenta Historica Universitatis Carolinae Pragensis, 1), 235-236: "Item eodem anno domini 1367, 20. die aprilis in plena congregacione facultatis magistri considerantes, quod multe inordinaciones et deformitates fierent per pronunciatores, et multi errores, ex quibus studentibus in artibus magnum dispendium, et toti facultati, imo toti universitati grave scandalum posset exoriri; nam quivis scholaris pronuntiavit, quidquid et quandocunque voluit, propria temeritate et scripta incorrecta et ignota, multos errores continentia dabant ad pennam, ipsa reverendis magistris false adscribendo, ut tanto plures sibi allicerent reportantes: facultas igitur cupiens illorum pronunciatorum temerariam abusionem supprimere et utilitati studentium fideliter providere, matura deliberacione prehabita et unanimi consensu statuerunt, quod quivis magistrorum poterit, super quolibet libro de facultate artium propria dicta dare, per se vel per alium pronunciando, poteritque scripta et dicta aliorum per se vel per alium pronunciare, dummodo sint ab aliquo vel aliquibus famoso vel famosis de universitate Pragensi, Parisiensi, vel Oxoniensi magistro vel magistris compilata, et dummodo ista antea fideliter correxerit, et pronunciatorem assumpserit idoneum et valentem. Baccalarii super libros Aristotelis et alios libros difficiles propria dicta dare, vel pronunciare non debebunt, dicta tamen aliorum magistrorum de ista universitate, vel aliorum de universitatibus, Parisiensi scilicet vel Oxoniensi, famosorum dare potuerunt, non quidem per alios, sed per semetipsos pronunciando, dummodo tamen decanum, qui pro tempore fuerit, prerequirant, ut ista committat alicui magistrorum, qui examinet, si sint dicta istius, cui adscribuntur, aut etiam sint correcta". 
the Physics by Iacobus Venetus and in the revision by William of Moerbeke. ${ }^{63}$ Interestingly, manuscripts of family $\beta$ do not refer either to De celo or to the Physics, but rather to the third book of the Meteorology ("ut dicitur in tertio huius"), in which this quotation cannot be found.

In question I.3, Oresme deals with the concepts of continuity and contiguity, defined by Aristotle in the fifth book of the Physics. Oresme argues against the view according to which the parts of continuous bodies have to move homogeneously. The Seine, for instance, consists of a continuous mass of water, but its parts can move in different directions: "Secana est una massa continua, et tamen una eius pars potest moveri versus unam partem et alia versus aliam". The Latin word for the Seine is "Secana". In most of the manuscripts of family $\beta$ this word is replaced by the expression "lancea mota ad latus". While this modification radically changes the meaning of the text, the reasoning is still applicable with some effort. A long body rotated around its core will have some of its parts moving in the opposite direction to the others. Yet it seems evident that, in contrast to what happens with a river, such an object moves homogeneously. Moreover, strictly speaking, its parts do not move in opposite directions, as they all have the same angular difference. In addition to this, the characterisation of continuous mass ("Secana est una massa continua") is more suitable to a river than to a long body such as a spear. The example found in the manuscripts of family $\beta$ is therefore not as pertinent as the one we find in $P$. Three manuscripts of family $\beta$ have other variants, semantically different from each other, but graphically quite similar: $B e, K a, S g$ and $P o$ read "locus", $L$ reads "lapis", $M$ and $U$ read "lacus", which restores, though in a slightly modified way, the original meaning of $P$.

The same question provides us with further examples of ways in which the text of family $\beta$ can be considered as a corruption of the text of $P$. An interesting case concerns the following passage: "Et cum arguebatur: 'materia Sortis et materia aeris circumstantis Sortem sunt continue; ergo Sortes et aer sunt continui', negetur antecedens". Manuscripts of family $\beta$ replace the term "consequentia" with the term "antecedens". In fact, Oresme would not have admitted the antecedent of his conclusion, namely that the matter of Socrates and that of the air around him are continuous. Based on Aristotle's Physics (v, 4, 228a20-22), Oresme maintains that in order for two bodies to be continuous,

63 Aristotle, Physica, viII, 1, 252 a 12-13, Translatio Iacobi Veneti (translatio vetus), eds. F. Bossier and J. Brams, Leiden/New York 1990 (Aristoteles Latinus vil 1-2) (2 vols.), 1, 28211: "At vero nichil inordinatum est eorum que natura et secundum naturam sunt"; Translatio Guillelmi de Morbeka (translatio noua), $A L$ VII 3, 373 ${ }^{10}$ : "At vero nihil inordinatum eorum quae natura et secundum naturam sunt". 
it is not enough for them to be juxtaposed: they must form a substantial unity (I.3, 14: "ad hoc quod aliqua sint continua, requiritur quod ultima eorum sint unum per se"). This is far from being the case with Socrates' matter and that of the air surrounding him, which possess different forms. The substitution of the term "consequentia" for the term "antecedens" should thus be considered as an error in manuscripts of family $\beta$.

The following paragraph of question I.3 contains a substitution that is easily explainable from a paleographical point of view. Manuscripts of family $\beta$ read "taliter" instead of "totaliter" in the following passage: "sciendum est quod illud dicitur fieri a motibus supercelestibus quod fit ab intelligentiis et corpore celesti totaliter moto". The reading "taliter" (in this way) does not seem appropriate in this context, as the preceding sentences did not expand upon celestial motions. The reading "totaliter" fits much better, since it implies a distinction that Oresme will employ in a subsequent question (I.6), namely the distinction between the particular motions of the planets and the general, unique motion of the celestial sphere, which is the ultimate cause of all of the effects in the sublunar region.

Question I.8, which concerns the relationship between motion and heat, contains another passage in which a quite uncommon word of $P$-at least, in the field of meteorology - has been replaced in manuscripts of family $\beta$ by a more widely used one in this context. One of the arguments against the principle that motion generates heat is that a hot soup cools down once it is moved. Manuscript $P$ reads: "videmus quod poreta calida, cum movetur, frigefit; unde videtur quod motus localis sit causa frigiditatis". Manuscripts of family $\beta$ replace the term "poreta" (soup) with "Boreas", the Greek name of a northern wind. This substitution allows manuscripts of family $\beta$ to eliminate an unexpected term in favour of another, graphically not so distant one, which seems to fit better in the semantic field of meteorology, since the term "Boreas" occurs several times in the second book of Aristotle's Meteorology. The reasoning is still applicable, because one could admit that as Boreas blows, it chills hot things: in this case, the adjective "calida" would no longer be a nominative feminine singular, but an accusative neuter plural. Nevertheless, the answer to the argument, at the end of the question, is better explained by the lectio "poreta". Manuscript $P$ states in fact that once the soup is moved (let us say, with a spoon), it cools down because it comes into contact with cold particles of air. In this sense, one can say that motion generates cold ("Ad primam, de motu porete, dicitur quod, cum poreta movetur, est in alio et alio aere continue recenti et frigido, qui plus infrigidat quam ex tali motu possit calefieri"). Manuscripts of family $\beta$ replace the term "poreta" with the term "Boreas" also in the answer, which makes the explanation less comprehensible. 
Another example of the superiority of $P$ over the manuscripts of family $\beta$ can be found in question I.9, in which Oresme inquires whether light generates heat. In the answer, Oresme states that fire is one of the luminous bodies ("unum corpus de corporibus lucidis"). Instead of this expression, most of the manuscripts of family $\beta$ ( $\mathrm{Be} \mathrm{Kl} \mathrm{Wr} \mathrm{Ba} \mathrm{Kr}{ }^{1} \mathrm{Kr}^{2} \mathrm{MSg}$; Wi omits this passage) have an incorrect reading: "minimum corpus de corporibus magnis". The reading "minimum" instead of "unum" can be explained by the graphical resemblance between the two abbreviated words in gothic handwritings. The replacement of "lucidis" by "magnis" could be the result of the first error: we can suppose that the copyists, finding this statement unusual, tried to interpret and to correct the rest of the sentence. Some fifteenth-century manuscripts present a reading that, without being completely correct, is closer to $P$ than to the majority of the manuscripts in family $\beta$. The reading of $L$ is namely "minimum corpus de corporibus" (without "magnis"); manuscripts $\mathrm{Ka}, \mathrm{Kr}^{3} \mathrm{Po}$ and $U$, for their part, have "unum corpus de corporibus magnis".

The same question contains another passage in which manuscript $P$ proves better than manuscripts from family $\beta$. A possible objection against the thesis according to which light generates heat is that some luminous bodies, such as fish scales and rotten wood, do not produce heat ("Octavo: multa lucent, sicut squame piscium et putredines quercuum, que tamen non sunt productiva caloris"). Oresme, who maintains that light generates heat, explains that it is not to be excluded that these bodies too can produce a small amount of heat. Moreover, it is possible that they have a cooling effect (virtusfrigefactiva) that is stronger than the heating one. ${ }^{64}$ At the end of the question, Oresme replies to the objections against the thesis according to which light generates heat. When it comes to the argument about fish scales and rotten wood, he refers to the body of the question (corpus questionis) instead of repeating the explanation he had already given. Manuscript $P$ has the following reading: "Ad octavam, de squamis piscium, dictum est in corpore questionis". Manuscripts of family $\beta$, for their part, transmit variants of this reading: "Ad octavam, de squamis piscium, videbitur in questione sequenti". Now the following question does not deal with light, but with the process of antiperistasis, namely the intensification of a quality due to the action of the contrary quality (I.10, Utrum contrarium circumstans suum contrarium fortificet ipsum). As Oresme does not come back to the heat-

64 I.9, 20: "De aliis lucidis, sicut sunt squame piscium, potest dici quod etiam lux ipsarum calefacit, sed hoc est bene remisse; et forte habent quasdam alias virtutes fortiores frigefactivas, quarum actio per huiusmodi lucem vel lumen remittitur; et ergo, quia virtus eius est fortior, aliquando effectus eius apparet et non effectus lucis, quamvis forte intensius appareret si non obstaret lumen". 
ing effect of fish scales and rotten wood in the rest of the text, we can consider the variant of family $\beta$ as erroneous.

In question I.8, Oresme shows that the circular motion of the sphere of fire and of the upper part of the sphere of air can be considered neither as natural nor as violent, but preternatural ("preter naturam"). While speaking about comets, in question I.15, Oresme refuses to admit that the circular motion of these bodies is a proof of their celestial nature. In doing so, he refers to the example of the sphere of fire and the upper part of the sphere of air, which both have a circular motion while being of a terrestrial nature: "Nec propter hoc oportet quod cometa sit de natura celi non plus quam aer vel ignis: talis enim motus non inest istis naturaliter, sed inest eis preter naturam, sicut prius dicebatur". Only manuscript $P$ has the correct reading, since he writes that the circular motion belongs to these spheres "preter naturam". All other manuscripts state that the motion of the sphere of fire and the upper part of the sphere of air is violent, which does not correspond to Oresme's opinion in question I.8. ${ }^{65}$

At the end of question 1.15, Oresme states that sometimes a comet takes the shape of a star, particularly when it is round: "sed tunc apparet quod sit una stella celi propter eius rotunditatem". Manuscript $P$ is the only witness which reads: "rotunditatem". All other manuscripts replace this term with "profunditatem", which makes no sense. If Oresme had meant to say that a comet could be mistaken for a star because of its distance from the Earth, he would have used the term "distantia".

In the following question, I.16, which also concerns comets, Oresme exposes a theory according to which the matter that constitutes these bodies is similar to the celestial one. In this sense, one could say that this substance does not shine because it is fiery, but because it is very similar to the matter of the stars, which are luminous: "Ulterius ymaginatur quod nec cometa fit per inflammationem huius exalationis ab igne, sed a natura alicuius planete, ita quod ista opinio ymaginabatur quod cometa est unum corpus valde simile nature stellarum, nec est ibi proprie inflammatio, sed illud corpus fit sic lucidum quia valde declinat ad naturam stellarum". Manuscripts of family $\beta$ replace the term "exalatio" with the term "inflammatio".

In the same question, Oresme excludes the possibility that the comet has a celestial nature. His main argument is that if this were the case, a comet would disappear under only two circumstances: 1 ) if it came too close to the

65 See for instance $L$ : "talis enim motus non est ignis naturalis, sed violentus, ut prius dicebatur"; $K l$ : "talis enim motus non est naturalis in istis, sed violente, sicut prius dictum est"; $U$ : "cum motus non est in istis naturalis, sed violenter, ut prius dicebatur". 
Sun, or 2) if it distanced itself too much from it. In the first case, the comet would be outshone by the Sun; in the second case, the comet would become invisible because it would no longer reflect the light of the Sun. Now, continues Oresme, a comet often disappears independently from its proximity to the Sun ("absque eius approximationem ad Solem"): "cometa non est de natura celi. Patet: nam, si sic, numquam deficeret a lumine nisi per approximationem et accessum eius ad Solem, sicut et alie stelle; sed hoc falsum. Patet falsitas, quia sepe cometa visus est deficere a lumine absque eius approximationem ad Solem". Manuscript $P$ is the only one which has the correct reading "absque eius approximationem ad Solem". Manuscripts of family $\beta$ invert the sense of the reasoning and invalidate it, since they state that comets have been seen disappearing because they came too close to the Sun or moved away from it. Manuscripts $\mathrm{Ka} K l \mathrm{~L} \mathrm{MSg} \mathrm{U}$ read for instance: "propter hoc quod approximabat ad Solem"; manuscript $B a$ has: "quando recessit a Sole".

Another interesting example can be found in question I.19, in which Oresme deals with the Milky Way. Oresme discusses an ancient theory on the Milky Way refuted by Aristotle. The adherents of this theory believed that the parts of the sky in which there are many stars attract a great quantity of exhalation. They claim that the exhalation acts as a mirror reflecting the light of the Sun ("tamquam speculum reflectens lumen Solis") and the Milky Way would result from this phenomenon. The reading "tamquam speculum reflectens lumen Solis" can be found only in manuscript $P$. Manuscripts of family $\beta$ have instead: "tamquam speculum reflectens istam exalationem". This variant is incorrect, because the exhalation is not the reflected object, but the reflective one!

In question II.1, Oresme asks whether rain is produced in the middle region of the air ("media regio aeris"). Among the arguments against this thesis, he states that fiery phenomena are produced in the middle region of the air, which seems to exclude the generation of humid phenomena in the same part of the atmosphere. Having shown how rain is produced in the middle region of the air, Oresme explains that both humid and fiery phenomena can be generated in this region of the atmosphere, and that the difference concerns the process. While humid phenomena are generated through the condensation of vapor, fiery phenomena are generated through the ejection (extrusio) of combustible matter downwards. The technical term "extrusio" is used in the Greek-Latin translation of the Meteorologica when discussing lightnings and thunders. ${ }^{66}$ The lectio difficilior "extrusio" is attested only in manuscript $P$ : "ad secundam: noua), $A L \times 2.2,82^{971}$ : "Sed ad contrarium inspissationis necessarium fieri extrusionem, uelut pyrenes ex digitis exilientes". 
'ibi generantur impressiones ignite', dico quod est alio modo, quia iste generantur ibi per extrusionem; aquee autem per condensationem". Manuscripts $B a$, $B a^{1}, K l, K r, K r^{1}, K r^{2}, M, W i, W r$ read "incensionem" (manuscripts $W i$ and $B a$ add "ipsius exalationis"). Manuscripts $\mathrm{Ka}, \mathrm{Kr}^{3}, \mathrm{Po}, \mathrm{L}, \mathrm{Sg}, \mathrm{U}$, have variants of this lectio: "intensionem vel extensionem". ${ }^{67}$ No manuscript except $P$ transmits the correct lectio difficilior "extrusionem".

In question II.2, Oresme asks whether rain, snow, dew and frost are of the same nature. Following Aristotle, he confirms this thesis and explains that the differences between these phenomena are only accidental. Manuscript $P$ is the only witness that has a good reading of this passage: "ad quartam dico quod huiusmodi bene habent descriptiones accidentales differentes, non autem substantiales". Manuscripts $K l$ and $W r$, along with manuscript $L$, have an incorrect lectio. While the first reads: "huiusmodi bene habent descriptiones, non autem essentiales"; the latter has: "huiusmodi bene habent descriptiones, non autem essentiales diffinitiones". Manuscripts $\mathrm{Ba}, \mathrm{Ba}, \mathrm{Kr}, \mathrm{Kr}^{1}, \mathrm{Kr}^{2}$, Wi have a different, but equally incorrect lectio, since they transmit variants of this sentence: "huiusmodi sunt bene descriptiones, sed non sunt diffinitiones essentiales".68 Manuscript $\mathrm{Kr}$ has a different, better text: "ad quartam dico quod huiusmodi habent bene descriptiones differentes, non autem dispositiones essentiales". Nevertheless, like the majority of manuscripts of family $\beta$, it omits the key word "accidentales". This term can be found only in manuscripts $\mathrm{Ka}, \mathrm{Kr}^{3}, \mathrm{M}^{1} \mathrm{Po}$ and $U$, which read: "huiusmodi bene habent descriptiones accidentales, non autem essentiales". ${ }^{69}$ In any case, no manuscripts of family $\beta$ transmits the correct reading.

In other cases, manuscripts of family $\beta$ contain readings that, while not being completely wrong, can be considered as lectiones faciliores. This occurs for instance in the following passage of question I.3: "Sol per accessum ad nos et recessum in obliquo circulo est causa generationis et corruptionis multorum in hoc mundo". Manuscripts of family $\beta$ write "a nobis" instead of "in obliquo circulo", which implies a repetition and a loss of information.

$67 S g$ : “intensionem vel extensionem"; $B e, K a, K r^{3} P o, S g, U$ : "vel per intensionem vel per extensionem"; $L:$ :vel per intensionem vel extensionem"; $M^{1}$ : "extensionem".

68 Ba: "huiusmodi sunt bene descriptiones, sed non sunt diffinitiones essentiales"; $W i$ : "huiusmodi sunt bene descriptiones, non autem diffinitiones essentiales"; $K r$ : "huiusmodi bene habent descriptiones, non autem diffinitiones essentiales"; $K r^{2}$ : "huiusmodi bene habent descriptiones, non autem diffinitiones essentiales". $S g$ and $B e$; "huiusmodi termini habent descriptiones, non autem essentiales diffinitiones".

69 The variant transmitted by $M^{1}$ can be considered as a corruption of the variant typical of this group: "ad quartam dico quod huiusmodi bene probat quod habent descriptiones accidentales, non autem essentiales". 


\section{The Central European Group: The Opposition between Family $\gamma$ and $\delta$} The opposition between $\delta$ and $\gamma$ is proved by a certain number of omissions and errors shared by $\gamma$, but not by $\delta$. For example, in the following cases, manuscripts of group $\gamma$ omit the words in italics, while manuscripts of group $\delta$ transmit them:

I.8, 6 deinde specialiter probatur quod motus celi non calefacit speram ignis I.16, 3 tertio ad idem: si esset aliqua talis exalatio ignita, aliquando deberet eclipsari, quia aliquando esset in umbra Terre causata ex obiectione Terre ad Solem.

II.1, 8 aliquando infra mediam regionem vapor elevatus, qui de natura sua est frigidus, quamvis accidentaliter sit calidus calore Solis, potest per antiparistasim reduci ad frigiditatem sibi naturalem et condensari in nubem $e t$ converti in aquam et sequitur pluvia.

The first question of the second book provides us with a very interesting example of the opposition between family $\gamma$ and family $\delta$. Oresme explains that rain can be generated in three ways. The text of $P$ reads as follows:

Quantum ad secundum, patet ex iam dictis quid sit modus generationis pluvie. Sciendum tamen quod tripliciter possunt generari nubes et pluvie. Uno modo per condensationem vaporis elevati in nubem; secundo modo per condensationem aeris in nubem a frigiditate medie regionis; tertio modo per repulsionem vaporis a media regione.

Manuscripts $K l$ and $W r$ omit the second modality by homoioteleuton:

Sciendum tamen quod tripliciter possunt generari nubes et pluvie. Uno modo per condensationem vaporis elevati in nubem a frigiditate medie regionis [ingrossatus $a d d$. $W r$ ] secundo modo per repulsionem vaporis a media regione.

A copyist must have noticed this anomaly and tried to remedy it by substituting "dupliciter" for "tripliciter". This variant is attested by manuscripts $B a, B a{ }^{1}, K r$, $K r^{1}, K r^{2}, M, W i$. Only manuscripts of sub-family $\delta$ transmit the correct version. ${ }^{70}$ We can thus distinguish three groups: 1) manuscripts which have the correct

70 Interestingly, manuscript $L$ exposes the three modalities of generation of rain, but announces this distinction with the adverb "dupliciter", instead of "tripliciter". 
version ( $P$ and sub-family $\delta) ; 2$ ) manuscripts which contain a homoioteleuton, namely $K l$ and $W r$ - the text of these manuscripts speaks of three modalities of the generation of rain, but mentions only two; 3 ) manuscripts which speak of two, and not three, modalities of the generation of rain. This is the case of all manuscripts of family $\beta$ with the exception of manuscripts $K l$ and $W r$ and of sub-family $\delta$. This lead us to infer that $\beta$ transmitted the correct version (with the three modalities) to $\delta$ and to $\gamma$. The latter omitted the second modality by homoioteleuton, but kept the adverb "tripliciter". This version is transmitted in manuscripts $K l$ and $W r$. The father of manuscripts $B a, B a^{1}, K r, K r l, K^{2}$, $M, W i$ noticed this inconsistency and corrected the adverb, writing "dupliciter" instead of "tripliciter".

\section{The Subfamily $B a B a^{1} K l K r^{1} K^{2} W i(\eta)$}

Within family $\gamma$, we can distinguish an important group of manuscripts, namely $\mathrm{Ba} \mathrm{Ba}{ }^{1} \mathrm{Kr} \mathrm{Kr}{ }^{1} \mathrm{Kr}^{2} \mathrm{Wi}$, which form a subfamily that I will call $\eta$. In what follows, I will present the list of shared accidents of this family based on the sample collated text:

Omissions of family $\eta$
1) I.1, 1 de se om. $\mathrm{Ba} \mathrm{Ba}{ }^{1} \mathrm{Kr} \mathrm{Kr}^{1} \mathrm{Kr}^{2} \mathrm{Wi}$
2) I.1, 1 sicut patet de se $o m . B a K r K r^{1} W i$ (sicut patet $K r^{2}$ )
3) I.1, 3 de se om. Ba Ba $\mathrm{Kr} \mathrm{Kr}^{1} \mathrm{Kr}^{2} \mathrm{Wi}$

Variants of family $\eta$
1) I.1, 1 de impressionibus metheorologicis] de eis $B a B a^{1} K r K r^{1} K^{2} W i$
2) I.1, 1 nota est] patet $\mathrm{Ba} B a^{1} \mathrm{Kr} \mathrm{Kr}^{1} \mathrm{Kr}^{2}$
3) I.1, 2 de impressionibus metheorologicis non potest simul haberi scientia et opinio] questio falsa $B a B a^{1} K r K^{1} K^{2}{ }^{2}$ i
4) I.1, 2 aristotelem] philosophum $B a B a^{1} \mathrm{Kr} \mathrm{Kr}^{1} \mathrm{Kr}^{2} \mathrm{Wi}$
5) I.1, 3 impressionibus metheorologicis] eis $\mathrm{Ba} \mathrm{Ba}^{1} \mathrm{Kr} \mathrm{Kr}^{1} \mathrm{Kr}^{2} \mathrm{Wi}$
6) I.1, 3 non est possibile de eis simul esse scientiam et opinionem] questio falsa $\mathrm{Ba} \mathrm{Ba}{ }^{1} \mathrm{Kr} K r^{1} \mathrm{Kr}^{2} \mathrm{Wi}$
7) I.1, 4 impressionibus metheorologicis] ipsis $B a B a^{1} \mathrm{Kr} \mathrm{Kr}^{1} \mathrm{Kr}^{2} \mathrm{Wi}$
8) I.1, 4 tenet] patet $B a B a^{1} \mathrm{Kr}^{1} \mathrm{Kr}^{2}$
9) I.1, 4 impressiones metheorologice] ipse $\mathrm{Ba} \mathrm{Ba} a^{1} \mathrm{Kr} \mathrm{Kr}^{1} \mathrm{Kr}^{2} \mathrm{Wi}$
10) I.1, 5 inordinate] inordinata $\mathrm{Ba} \mathrm{Ba}{ }^{1} \mathrm{Kr} \mathrm{Kr}^{1} \mathrm{Kr}^{2} \mathrm{Wi}$
11) I.1, 5 est nota] patet $B a B a^{1} K r K r^{1} K r^{2} W i$
12) I.1, 5 aristotelem] philosophum $B a B a^{1} \mathrm{Kr} \mathrm{Kr}^{1} \mathrm{Kr}^{2} \mathrm{Wi}$
13) I.1, 6 assensus autem] et talis assensus $B a B a^{1} \mathrm{Kr} \mathrm{Kr}^{1} \mathrm{Kr}^{2} \mathrm{Wi}$
14) I.1, 6 allegabatur] allegatum est $B a B a^{1} \mathrm{Kr} \mathrm{Kr}^{1} \mathrm{Kr}^{2} \mathrm{Wi}$ 
15) I.1, 6 aristotelem] philosophum $\mathrm{Ba} \mathrm{Ba}{ }^{1} \mathrm{Kr} \mathrm{Kr}^{1} \mathrm{Kr}^{2} \mathrm{Wi}$

16) I.1, 6 syllogismus dyalecticus et syllogismus demonstrativus dyalecticus quidem qui generat opinionem demonstrativus vero qui generat scientiam qui generat scientiam] syllogismus dyalecticus qui generat opinionem et syllogismus demonstrativus qui generat scientiam igitur etc. $\mathrm{Ba} \mathrm{Ba}{ }^{1} \mathrm{Kr} \mathrm{Kr}^{1} \mathrm{Wi}$ (om. $\mathrm{Kr}^{2}$ )

17) II.1, 2 ex eo quod] eo quod $\left.B a B a^{1} K r K r l W i\right]$ ex se quod $M$ ] ex eo quia $B e$ $\mathrm{L} \mathrm{Ka} \mathrm{Kr}{ }^{3} \mathrm{Po} \mathrm{Sg}$

18) II.1, 3 exalationis] exalationum $\mathrm{Ba} \mathrm{Kr} \mathrm{Kr}{ }^{2}$

19) II.1, 4 aliquando] quandoque $\mathrm{BaBa}{ }^{1} \mathrm{Kr} \mathrm{Kr}^{1} \mathrm{Kr}^{2} \mathrm{Wi}$

20) II.1, 4 nam] quia $B a K K r^{1} K^{2} W i$

21) II.., 5 in primo tractatu et primo capitulo huius secundi] in primo capitulo tractatus primi secundi huius $\mathrm{Ba} \mathrm{Kr} \mathrm{Kr}^{1} \mathrm{Kr}^{2} \mathrm{Wi}$ ] in primo capitulo tractatus primi huius secundi $K l]$ in primo capitulo tractatu primo huius secundi libri $W r]$ in primo capitulo tractatus primi secundi $L]$ in primo capitulo primo tractatu secundi primi libri secundi $M$ ] libro secundo capitulo primo tractatus primi $B e S g$ ] in primo capitulo tractatus primi huius secundi libri $P o U$ ] primo in primo capitulo tractatus primi secundi huius $\left.\mathrm{Ba}^{1}\right]$ in primo capitulo tractatus primi huius secundi $\mathrm{Ka}$

22) II.1, 6 primo exponende sunt alique conclusiones pro quesito] primo videndum est de loco generationis pluviarum $\mathrm{Ba} \mathrm{Ba}{ }^{1} \mathrm{Kr} \mathrm{Kr}^{1} \mathrm{Kr}^{2} \mathrm{Wi}$

23) II.1, 6 quoad figuram] de figura $B a B a^{1} \mathrm{Kr} \mathrm{Kr}^{1} \mathrm{Kr}^{2} \mathrm{Wi}$

24) II.1, 6 de diversitate pluviarum quod quantitatem] de quantitate pluviarum $\mathrm{Ba} \mathrm{Ba} \mathrm{Kr} \mathrm{Kr}^{1} \mathrm{Kr}^{2} \mathrm{Wi}$

25) II.1, 6 de diversitate pluviarum quoad modum cadendi guttarum] de modo cadendi pluviarum $\mathrm{Ba} \mathrm{Ba}{ }^{1} \mathrm{Kr} K r^{1} \mathrm{Kr}^{2} \mathrm{Wi}$

26) II.., 6 de pluviis quoad loca et regiones ubi fiunt] de regionibus in quibus solent cadere pluvie $\mathrm{BaBa}{ }^{1} \mathrm{Kr} \mathrm{Kr}^{1} \mathrm{Kr}^{2} \mathrm{Wi}$

27) II.1, 6 in media regione aeris] ibi $B a B a^{1} K r^{1} K r^{2} W i$

Additions of family $\eta$

II.1, 3 et] deinde $a d d . B a B a^{1} K r K r^{1} K^{2} W i$

Looking at the most significant variants, we notice that the members of family $\eta$ often present certain abbreviated forms in order to avoid repetitions. For example, they employ the pronominal forms eis and ille instead of repeating impressionibus metheorologicis and impressiones metheorologice (examples 5, 7). Similarly, this subfamily writes "questio falsa", instead of repeating the final formula for the conclusion (example 6). Another feature of the manuscripts of this group is that they always refer to "Aristoteles" as "Philosophus" (examples $4,12$ and 15$)$. 
But what is more interesting is that the manuscripts of group $\eta$ frequently organize the text differently from the other witnesses. This is already evident in the first question, as these manuscripts omit the divisio textus at the beginning of the answer $(P$ : "In ista questione primo videndum quid est scientia et quid opinio; secundo, quot modis aliquid dicitur 'scibile' et 'opinabile'; tertio, an idem sit scibile et opinabile; quarto respondendum est ad quesitum"). Consistently with this choice, manuscripts of group $\eta$ do not introduce the different articles of the answer with expressions like "quantum ad primum" and "quantum ad secundum", as the other witnesses do, but only with generic formulas such as "notandum est". Sometimes, the difference in the articulation of the text between subfamily $\eta$ and the other witnesses goes deeper, as shown by the following example taken from question I.2:

Text of the other witnesses ${ }^{71}$

Quantum ad tertium, sit prima conclusio: universum et omnia que sunt in ipso sunt bene ordinata loco, tempore et proportione, comparando quodlibet eorum ad omnia alia.

Probatur, quia omnia sunt bene disposita que sunt in universo; igitur omnia que sunt in universo sunt bene ordinata. Consequentia clara est de se. Antecedens patet, quia duodecimo Metaphysice dicitur quod entia nolunt male disponi.

Secundo: omnia que sunt in universo sunt disposita secundum quandam consonantiam et armonicam proportionem; igitur omnia que sunt in universo sunt bene ordinata.

\section{Text of family $\eta$}

Tunc etiam ponuntur alie conclusiones. Prima est: universum et omnia que sunt in ipso sunt bene ordinata loco, tempore et proportione. Patet, quia dicitur duodecimo Metaphysice: entia nolunt male disponi.

Secundo probatur eadem conclusio, nam elementa sunt bene disposita que sunt in mundo et in universo; igitur conclusio est vera. Consequentia tenet et antecedens patet per auctoritatem allegatam ex duodecimo Metaphysice.

Tertio: omnia que sunt in universo sunt disposita secundum consonantiam et armonicam proportionem; igitur conclusio vera.

Just as in question I.1, the divisio textus at the beginning of the answer is missing $(P$ : "In ista questione primo videndum est quid sit intelligendum per 'impres-

71 I have followed the text of $P$, but I collated it with that of the other witnesses. 
siones metheorologice'; secundo videndum est qualiter fiant secundum naturam; tertio videndum est quali ordine fiant"). As we have seen above, this fact determines the omission of introductory formulas such as "quantum ad primum" and "quantum ad secundum", in manuscripts of family $\eta$. The conclusion referred to as the first of the third article by the other manuscripts is therefore presented in manuscripts of family $\eta$ as the first among "alie conclusiones". But there is more. In manuscripts of family $\eta$, the demonstration of the first conclusion is subdivided into three arguments rather than two. However, if we compare the third argument in family $\eta$ with the second argument in the other manuscripts, we notice that this difference does not affect the content of the text, but only its structure.

The members of this family also omit the divisio textus of questions I.3, I.5, I.6, I.18. In question I.10, the divisio textus is reorganized and slightly reworded. In this case the divisio textus consists of two paragraphs (the first beginning with the words: "in ista questione primo videndum est"; the second beginning with the words: "quantum ad primum"). The order of the two paragraphs in family $\eta$ is inverted with respect to the rest of the tradition. Moreover, the text has been slightly modified:

\section{Text of the other witnesses}

$\langle 1\rangle$ In ista questione primo videndum est an unum contrarium possit movere aliud localiter; secundo videndum est de modo per quem unum contrarium movet suum contrarium localiter; tertio videndum est an ex condensatione alicuius subiecti caliditas vel frigiditas illius subiecti intendantur.

\section{$\langle 2\rangle$ Quantum ad primum, primo sciendum} est quod questio et illud quod dicetur in ista questione debet intelligi de qualitatibus primis, sicut sunt caliditas, frigiditas etc., et non de qualitatibus secundis, sicut sunt albedo, nigredo et consimilia. Unde albedo posita iuxta nigredinem non facit ipsam intensiorem, sed bene facit quod

\section{Text of family $\eta$}

$\langle 2\rangle$ Notandum primo quod questio et ea que dicentur in questione debent intelligi de qualitatibus primis, sicut sunt caliditas, frigiditas, humiditas et siccitas, et non de qualitatibus secundis, sicut sunt albedo, nigredo et consimilia. Unde albedo posita iuxta nigredinem non facit ipsam intensiorem, sed facit eam bene magis apparere: contraria enim iuxta se posita magis elucescunt.

$\langle 1\rangle$ In ista questione taliter intellecta primo videndum est utrum contrarium possit movere aliud localiter et fugare ipsum; secundo videndum est quomodo unum contrarium movet aliud localiter; tertio, utrum ex condensatione alicuius subiecti fiat fortificatio et intensio qualitatis et virtutis existentis in ipso. 
(cont.)

Text of the other witnesses

Text of family $\eta$

apparet intensior: contraria enim iuxta se

posita magis elucescunt.

While in manuscript $P$ and in the other witnesses of family $\beta$ the divisio textus is followed by an explanation of the qualities concerned by the mechanism of antiperistasis, manuscripts of subfamily $\eta$ invert these two points. Consistently with this inversion, the explanation concerning the qualities is not introduced by the expression "quantum ad primum", but, more generally, by the verb "notandum". Moreover, having introduced this explanation before the divisio textus, the latter opens with the words "in ista questio taliter intellecta". We thus notice that the manuscripts of subfamily $\eta$ not only structure the text differently, but also reformulate it accordingly.

In question I.12, the divisio textus transmitted by the manuscripts of subfamily $\eta$ differs slightly from the version that can be found in the other witnesses:

Text of the other witnesses

Text of family $\eta$

Breviter in ista questione videndum est quid sit exalatio et quid vapor; secundo videndum est de comparatione istorum ad invicem; tertio respondendum est ad quesitum.

In ista questione videndum est de natura exalationum et vaporum; secundo de comparatione ipsorum ad invicem; tertio qualiter et quarum impressionum ipse sunt materie.

The same applies to the following question, I.13, in which the gap between the manuscripts of family $\eta$ and the other witnesses further increases:

Text of the other witnesses

In ista questione videndum est quomodo diversificantur huiusmodi impressiones; secundo videndum est de causis harum

\section{Text of family $\eta$}

In ista questione numerande sunt experientie; secundo dicetur de causis illarum impressionum; tertio de modo genera- 
(cont.)

Text of the other witnesses

Text of family $\eta$

impressionum et in generali et in speciali, tionis et variationis; quarto movebuntur quibus visis patet faciliter responsio ad dubia.

quesitum.

In conclusion, the differences between family $\eta$ and the other witnesses do not concern doctrinal elements, but only the argumentative structure. These variants are not isolated and did not occur by accident during the copying process, but derive from a systematic reworking of the text. In some cases, the structure of the text is made more explicit and more formulaic, so that every paragraph begins with a piece of metadiscourse allowing the student and teacher to know exactly where in the text they are. It is therefore possible that the original text of this family represents a slightly modified version of Oresme's Questions. As indicated by the colophona of the manuscripts, this version circulated at the University of Prague.

Within family $\eta$, manuscripts $B a$ and $K$ contain some variants which stand out from the other witnesses:

1) I.1, 2 probatur] etiam $a d d . B a K r$

2) I.1, 3 cum] quia $\mathrm{Ba} \mathrm{Kr}$

3) I.1, 3 sunt complexa que qualitercumque sit sic significent] nec qualitercumque est fuit vel erit significent $\mathrm{Ba} \mathrm{Kr}$

4) I.1, 5 non videtur posse haberi] non potest haberi $\mathrm{Ba} \mathrm{Kr}$

5) I.1, 5 autem om. $\mathrm{Ba} \mathrm{Kr}$

6) I.1, 6 circa finem primi posteriorum] primo posteriorum circa finem $\mathrm{Ba} \mathrm{Kr}$

7) I.1, 6 per subiectum om. $\mathrm{Ba} \mathrm{Kr}$

8) II.1, 2 generationis impressionum ignitarum] impressionum ignitarum $\mathrm{Ba}$ $\mathrm{Kr}$

9) II.1, 2 generationis om. $\mathrm{Ba} \mathrm{Kr}$

Manuscripts $B a^{1}$ and $K r^{l}$ are, for their part, very close to each other, since they share some unique variants:

1) I.1, 2 eo] istis $B a^{1} K^{1}$

2) I.1, 3 non sint complexa que qualitercumque sit sic significant] non sint complexe nec qualitercumque fuit est vel erit sic significant $B a^{1} \mathrm{Kr}^{1}$ 


\section{Manuscripts $K l$ and $W r$}

Manuscripts $K l$ and $W r$ display a certain number of shared accidents.

Variants shared by manuscripts $K l$ and $W r$

1) I.1, 2 sed non est idem quod possibile est aliter se habere et quod impossibile est aliter se habere] sed non est idem impossibile aliter se habere et possibile aliter se habere $K l W r$

2) I.1, 6 quod autem de ipsis potest esse opinio patet] et patet $K l]$ ut patet $W r$

3) I.1, 6 syllogismus dyalecticus et demonstrativus dyalecticus quidem qui generat opinionem demonstrativus vero qui generat scientiam] syllogismus dyalecticus qui generat opinionem et syllogismus demonstrativus qui generat scientiam $\mathrm{Kl} W r$

4) II.1, 6 pluviarum] pluviali $K l W r$

5) II.1, 6 diversitate] varietate $K l W r$

6) II.1, 7 frigiditas] frigus $K l W r$

Additions shared by manuscripts $K l$ and $W r$

1) I.1, 6 alii] scilicet quod de impressionibus metroloycis potest esse scientia et opinio add. $K l W r^{72}$

2) I.1, 6 opinio] igitur etc. $a d d$. $K l W r$

3) II.1, 1 debet] primo add. $K l W r$ (this variant is shared also by manuscript $M$ )

4) II.1, 1 sibi] non add. $K l W r$ (manuscript $M$ has "non" instead of "sibi")

Omissions shared by manuscripts $K l$ and $W r$

I.1, 6 posito enim] posito $K l W r$

Inversions shared by manuscripts $K l$ and $W r$

I, 6 a te scite] scite a te $K l W r$

In some cases, $K l$ and $W r$ are the only witnesses sharing the variants of $P$ :

I.1, 5 inordinatiorem] inordinatam $P$ Wr Kl

In addition to the variants of $K l, W r$ presents some individual accidents:

I.1, 4 corruptibiles] corporales $W r$

I.1, 6 possibile sit de eis] de ipsis possibile sit $K l]$ de impressionibus possibile sit $W r$

It is therefore possible that $W r$ was copied from $K l$.

72 It is worth noticing that in this passage $L$ has a similar addition: "scilicet quod de impressionibus metheorologicis posset esse opinio et scientia". 


\section{Manuscript $M$}

Within group $\gamma$, manuscript $M$ has a special place, since it contains a lot of unique accidents, the majority of which can be considered as errors:

1) I.1, 2 impressionibus] scientia $M$

2) I.1, 3 sunt complexa que qualitercumque sit sic significant] non sunt complexa nec qualitercumque fiunt sicut fiunt $M$

3) I.1, 4 esse] haberi $M$

4) I.1, 5 est nota] nota $M$

5) I.1, 5 non debent fieri inordinate extra semper et frequenter] non debent fieri ordinate extra semper et frequenter $M$

6) I.1, 5 patet] arguitur $M$

7) I.1, 6 opinionem om. $M$

8) I.1, 6 propositionis] talis add. $M$

9) I.1, 6 ipse enim est] quia pater est $M$ (all other manuscripts of family $\beta$ read: quia pater tuus est)

10) I.1, 8 videndum est om. $M$

11) II.1, 1 primo quod non om. $M$

12) II.1, 1 sibi] non $M$ (sibi non $K l W r)$

13) II.1, 2 idem non est] non videtur esse idem $M$ (idem non videtur esse $B a$ $B a^{1} B e K l K r K r^{2} K r^{3} U S g$ Wi Wr $)$

14) II.1, 2 hoc esset per istum modum quod om. $M$

15) II.1, 4 aeris om. $M$

16) II.1, 4 generationis] generatio $M$

17) II.1, 4 videt] videns $M$ ]

18) II.1, 4 et hoc] secundo $M$

19) II.1, 4 generari] generare $M$

20) II.1, 7 sed om. $M$

21) II.1, 7 condensare] congelare $M$

Curiously, manuscript $M$ often adds or omits certain prefixes that invert the sense of the text. Sometimes these inversions are the result of the substitution of one word by another. The italicized words in the following examples indicate the major differences between the other witnesses and $M$ :

1) I.1, 5 non debent fieri inordinate extra semper et frequenter] non debent fieri ordinate extra semper et frequenter $M$

2) I.1, 14 quarta conclusio impossibile est ab aliquo idem complexum simul sciri et opinari] quarta conclusio possibile est de aliquo idem simul sciri et opinari $M$

3) I.2, 1 et dicit ibidem commentator impossibile est ut famosum sit falsum secundum totum] et ibidem dicit commentator quod possibile est ut famosum sit falsum secundum totum $M$ 
4) I.2, 10 secundo sciendum est quod huiusmodi impressiones fiunt sub orbe lune in regione elementari et ut in pluribus fiunt super nos] secundo est sciendum quod impressiones fiunt sub orbe lune in regione elementari et ut in pluribus fiunt $s u b \operatorname{nos} M$

5) I.3, 15 negetur antecedens] negetur consequentia $M$

6) I.3, 19 quia lumen est qualitas sensibilis] quia lumen est qualitas insensibilis $M$

7) I.3, 22 ad primam concedo quod mundus iste inferior non est continuus lationibus superioribus] ad primam concedo quod iste mundus inferior est continuus celo $M$

8) I.5, 5 quinto alique veritates sunt ita evidentes quod intellectus non potest eis assentire cum formidine ergo circa illas non contingit opinio] quinto alique veritates sunt ita evidentes quod intellectus non potest eis assentire cum formidine ergo circa illas non contingit scientia $M$

9) I.8, 7 sed quia igni naturaliter inest moveri sursum sequitur quod sibi non inest naturaliter moveri circulariter et per consequens inest sibi violenter] sed quia igni naturaliter inest moveri sursum sequitur quod sibi non inest naturaliter moveri circulariter et per consequens non inest sibi violenter M

Because these transformations occur systematically, one is tempted to believe that Iohannes Krickpaum, the scribe, did this on purpose. In fact, his goliardic temperament is witnessed by the colophon, in which he claims to have copied the text with his feet, instead of with his hands (see above, the description of the manuscript).

\section{The Group Be Ka Kr ${ }^{3} L M^{1} \mathrm{Po} S g U(\delta)$}

As we have seen above, a certain number of accidents within family $\beta$ counterpose manuscripts $B a B a^{1} K l K r K r^{1} K r^{2} M W i(\gamma)$ to manuscripts $B e K a K r^{3} L M^{1}$ $P o S g U(\delta)$, which were all copied in the fifteenth century. The collated passage from the first question confirms the existence of family $\delta$ :

1) I.1, 3 esse scientia] haberi scientiam $\mathrm{Be} \mathrm{Ka} \mathrm{Kr}{ }^{3} \mathrm{~L} \mathrm{Po} \mathrm{U}$

2) I.1, 5 non videtur posse haberi] non videtur posse esse $\mathrm{Be} \mathrm{Ka} \mathrm{Kr}{ }^{3} \mathrm{Po} \mathrm{Sg}$ $U$

3) I.1, 5 in littera] in primo illius libri $\mathrm{Be} \mathrm{Ka} \mathrm{Kr}{ }^{3} \mathrm{LPo} \mathrm{SgU}$

4) I.1, 6 est] esset $\mathrm{Ba} \mathrm{Be} \mathrm{Ka} \mathrm{Po} \mathrm{SgU}$ (esse $\mathrm{Kr}^{3}$ )

5) I.1, 6 esset] sit $\mathrm{Be} \mathrm{Ka} \mathrm{Kr}{ }^{3} \mathrm{Po} \mathrm{Sg} \mathrm{U}$

6) I.1, 6 simul esse] esse $K a K r^{3} L P o U$ 
Manuscripts $L S g(\varepsilon)$

Within this group, $L$ displays a quite individual behaviour. This manuscript is particularly close to $S g$, as shown by these unique shared accidents:

I.2, 20 coniunctio] effectus $L S g$

I.2, 21 fiunt] difformiter se habent $L S g$

I.11, 19 basse] spisse vel spissiores sive bassiores $L S g$ (spisse et spissiores $\mathrm{Ba} K l)$

I.11, 19 figure] figure sive dispositionis $L S g$ (dispositionis $B a K l$ )

I.16, 21 coniunctione] vel ex commixtione $a d d . L S g$

II.4, 1 tardior] minor $L S g$

II.7, 4 nec hoc facit alias calor elevans illam aquam sursum] nec hoc fit per aliquem calorem trahentem vel elevantem illam aquam sursum $L$ $S g$

\section{Manuscripts $\mathrm{Ka} \mathrm{Kr}^{3} \mathrm{LPo} U(\zeta)$}

Within family $\delta$, manuscripts $\mathrm{Ka} \mathrm{Kr}^{3}\left(M^{I}\right)$ Po $U(\zeta)$ are very close to each other, as is evident from the list of their common shared accidents:

Additions of family $\zeta$

1) I.1, 1 de se] sed $a d d$. $K a U$

2) I.1, 2 secundo] arguitur sic add. Ka Po U

3) I.1, 4 quarto] arguitur sic add. $K a U$ (sic add. Po)

4) I.1, 4 de] sed de $\mathrm{Ka} \mathrm{K}^{3}$ (et de $\mathrm{Be} S g U$ )

5) I.1, 5 quinto] arguitur sic add. $\left.\mathrm{Ka} \mathrm{Kr}^{3} \mathrm{U}\right]$ sic $\mathrm{add}$. Po

Variants of family $\zeta$

1) I.1, 2 sed non est idem quod impossibile est aliter se habere et quod possibile est aliter se habere] sed non est idem quod possibile est aliter se habere et quod impossibile est aliter se habere $\mathrm{Ka} \mathrm{Kr}^{3} \mathrm{Po} U$

2) I.1, 3 esse scientia] haberi scientiam nec esse $\mathrm{Ka} \mathrm{Kr}^{3} \mathrm{Po} \mathrm{U}$

3) I.1, 3 non sunt complexa que qualitercumque sit sic significant] non sint complexa quia qualitercumque se habent sic significant $\mathrm{Ka}$ Po $\mathrm{U}$

4) I.1, 6 de ipsis] de impressionibus metheorologicis $\mathrm{Ka} \mathrm{Kr}^{3} \mathrm{Po} \mathrm{U}$

5) I.1, 6 haberes opinionem de patre tuo] haberes de patre tuo scientiam $\mathrm{Ka}$ $\left.\mathrm{Kr}^{3} \mathrm{Po}\right]$ haberes scientiam de patre tuo scientia $U$

6) I.1, 6 tamen hoc non obstante] illo tamen non obstante $\mathrm{Ka} \mathrm{Kr}^{3} \mathrm{U}$

7) II.1, 1 debet ibi] ibi debent $K a M^{1} P o U$

8) II.1, 6 pluviis] pluvia $\mathrm{Ka} \mathrm{Kr}{ }^{3} \mathrm{Po} U$

9) II.1, 7 ecce causas sufficientes in media regione aeris] ergo sunt in media regione aeris cause sufficientes $\left.B a B a^{l} K l K r M W i\right]$ igitur in media regione 
aeris sunt cause sufficientes $B e K r K r^{1} K r^{2} S g$ ] ergo in media regione aeris cause sufficientes $W r$ ] ideo sunt cause sufficientes in media regione aeris $K a K r^{3} M M^{1}$ Po $U$

10) II.1, 7 etiam] et $K a K r^{3} M^{1} P o$

Omissions of family $\zeta$

1) I.1, 3 ex primo] primo $\mathrm{KaPo} U$ (om. $\mathrm{Kr}^{3}$ )

2) I.1, 4 posse om. $\mathrm{Ka} \mathrm{Kr}^{3} \mathrm{Po}$

3) I.1, 6 in oppositum est aristoteles et albertus et alii] in oppositum est aristoteles et alii $\mathrm{Ka} \mathrm{Kr}^{3}$ ] in oppositum autem est aristoteles et alii $U$

4) I.1, 6 hoc maxime] maxime $\mathrm{Ka} \mathrm{Kr}^{3} \mathrm{Po}$

5) I.1, 6 sed om. $\mathrm{Ka} \mathrm{Kr}{ }^{3} \mathrm{Po}$

6) I.1, 6 simul esse] esse $K a K r^{3} P o U$ (manuscript $L$ also shares this variant)

7) I.1, 6 et demonstrativus dyalecticus quidem qui generat opinionem demonstrativus vero qui generat scientiam] qui generat scientiam $\mathrm{Be} \mathrm{Kr}$ $P o S g U$ (manuscript $M$ also shares this variant)

Inversions and transpositions of family $\zeta$

1) I.1, 2 consequentia tenet inv. Ka Po U

2) I.1, 2 sed non est idem quod impossibile est aliter se habere et quod possibile est aliter se habere] sed non est idem quod possibile est aliter se habere et quod impossibile est aliter se habere $K a K^{3} U$

3) I.1, 3 non est possibile de eis simul esse] non est possibile de eis esse simul $\mathrm{Ka} \mathrm{Kr} \mathrm{r}^{3} \mathrm{U}$

4) II.1, 1 debet ibi] ibi debent $K a M^{1} P o U$

Within this group, $K r^{3}$ and $P o$ are particularly close, as they share some unique variants:

1) I.1, 1 igitur questio est falsa] igitur etc. $\mathrm{Kr}^{3} \mathrm{Po}$

2) I.1, 6 iret] ambulat $\mathrm{Kr}^{3} \mathrm{Po}$ ] ambularet $\mathrm{Be} L \mathrm{MSg}$ ] ambulans $\mathrm{Ba} \mathrm{Ba} \mathrm{I}^{1} \mathrm{Kl} \mathrm{Kr}$ $\left.K r^{1} K r^{2} W i W r\right]$ ambulet $K a U$

3) I.1, 6 conclusio] propositio $\mathrm{Kr}^{3} \mathrm{Po}$

4) I.1, 6 istam conclusionem] de ista propositione $K r^{3} \mathrm{Po}$ (de ista conclusione $\mathrm{Ka} \mathrm{Kl} \mathrm{Kr^{2 } U W r}$ )

5) I.1, 6 posset esse] sit $K^{3} P o$ (esset $B a B a^{1} B e ~ K a K l K r K r^{1} K r^{2} L M S g U W i$ Wr)

6) II.1, 3 est om. $K r^{3} M^{1} P o$

Manuscript $\mathrm{Kr}^{3}$ seems to be the worst witness of this group. 


\section{Manuscripts $B e$ and $S g$}

Manuscripts $B e$ and $S g$ are particularly close to each other:

Additions shared by manuscripts Be Sg

1) I.1, 2 secundo] arguitur add. Be $S g$

2) I..1, 2 ratione] sic add. $B e S g$

3) I..1, 4 quarto] sic add. Be $S g$

4) I.1, 4 autem ut videtur non possunt formari propositiones necessarie] non est scientia nec possunt formari propositiones necessarie $\mathrm{Be} \mathrm{Ka} \mathrm{Kr}^{3} \mathrm{Po} \mathrm{Sg}$ $U$

5) I..1, 5 quinto] sic add. Be $S g$

6) II.1, 1 non] nam $a d d . B e S g$

7) II.1, 3 est] verum add. $B e S g$

Omissions shared by manuscripts Be Sg
1) I.1, 1 igitur etc. om. $\mathrm{Be} \mathrm{Sg}$
2) I.1, 2 simul haberi] haberi $B e S g$
3) I.1, 2 autem om. $\mathrm{Be} S g$
4) I.1, 3 generationis om. $\mathrm{Be} \mathrm{Sg}$
5) II.1, 6 guttarum om. $\mathrm{Be} \mathrm{Sg}$
6) II.1, 7 maior est nota om. $\mathrm{Be} \mathrm{Sg}$

Variants shared by manuscripts Be Sg

1) I.1, o circa librum metheororum qui est quartum naturalium queritur primo] circa primum metheororum queritur primo $\mathrm{Be} S g$

2) I.1, 1 sicut patet de se] sicut clarus est $B e S g$

3) I.1, 3 non est possibile de eis simul esse] non est possibile de eis simul habere $S g$ ] non est possibile simul de eis habere $B e$

4) I.1, 3 cum] nam $\mathrm{Be} S g$

5) I.1, 5 inordinatam] inordinatissimam $\mathrm{Be} S g$

6) I.1, 6 sed hoc non quia de eadem re possibile est] sed hoc non est impossibile ymo possibile est de eadem re $S g$ ] sed hoc non est impossibile ymo possibile est de aliqua eadem re $B e$

7) I.1, 6 haberes opinionem de patre tuo] haberes de patre tuo opinionem $B e$ $\mathrm{Sg}$

8) II.1, 1 locum sibi naturalem] suum locum naturalem $\mathrm{Be} S g$

9) II.1, 4 existens] steterat $\mathrm{Be} S g$ ] stans $B a^{1} \mathrm{Ka} \mathrm{Kl} \mathrm{Kr}^{1} \mathrm{Kr}^{2} \mathrm{Kr}^{3} \mathrm{MU} \mathrm{Wi} \mathrm{Wr}$ (steteat $L$ stetit $B a$ )

10) II.1, 4 videt] et vidit $B e S g$ (et videt $L$ )

11) II.1, 6 ipsius pluvie] ipsarum $B e S g$ (and $L$ ) 
12) II.., 6 pluviarum quoad quantitatem] guttarum ipsius pluvie $\mathrm{Ka} \mathrm{Kl} \mathrm{Kr}^{3} \mathrm{M}$ $\mathrm{UWr}$ guttarum $\mathrm{Be} S g$

13) II.1, 6 quoad loca et regiones] quoad regiones et loca $B e S g$ ] quoad regiones et ad loca $K l L M W r$

14) II.1, 6 prima] hec $B e S g$

15) II.1, 7 vaporem elevatum] vapores $B e S g$ (and $W r$ )

16) II.1, 7 elevatum in nubem et convertere in aquam] et convertere in nubem et sic sequitur pluvia $B a B a^{1} K l K^{1} \mathrm{Kr}^{3} \mathrm{LWi}$ ] et convertere in nubem et ut sic sequitur pluvia $K r$ ] et convertitur in nubem et sic sequitur pluvia $\mathrm{Kr}^{2}$ ] et convertere in nubem et sequitur pluvia $\mathrm{KaMU}$ ] et vertere in pluvias et sequitur inde pluvia $\mathrm{Be} S g$

17) II.1, 7 pluvie] pluviarum $B e \mathrm{Kl} S g \mathrm{Wr}$

18) II.., 7 et fieri] quod fieret $B a B a^{1} \mathrm{Ka} \mathrm{Kl} \mathrm{Kr} \mathrm{Kr}^{1} \mathrm{Kr}^{2} \mathrm{Kr}^{3} \mathrm{~L} M U W i \mathrm{Wr}$ ] quod fiat $\mathrm{Be} S g$

19) II.1, 7 potest reliquum generari] potest alterum generari $\mathrm{Ba} \mathrm{Ba}{ }^{1} \mathrm{Ka} \mathrm{Kl} \mathrm{Kr}$ $\mathrm{Kr}^{1} \mathrm{Kr}^{3} \mathrm{LMUWi} \mathrm{Wr}\left(\right.$ aliud $\left.K r^{2}\right)$ ] potest generari alterum $\mathrm{Be} S g$

Besides sharing the accidents of $S g, B e$ has some unique accidents, the majority of which can be regarded as lectiones deteriores (examples 1, 3, 5):

1) I.1, 3 non sint complexa que qualitercumque sit sic significant] non sunt complexa que qualitercumque sint sic significant $B e$

2) I.1, 6 possibile sit de eis] de ipsis possibile sit $S g$ ] de ipsis sit possibile $B e$

3) I.1, 6 esset om. Be

4) I.1, 6 sed hoc non quia de eadem re possibile est] sed hoc non est impossibile ymo possibile est de eadem re $S g$ ] sed hoc non est impossibile ymo possibile est de aliqua eadem re $B e$

5) I.1, 6 super manus et pedes] per pedes et manus $B e$

6) II.1, 6 primo exponende sunt] primo ponende sunt $S g$ ] ponende sunt primo $B e$

7) II.1, 7 in illo loco possunt generari pluvie in quo $S g$ ] in nullo locu possunt generari pluvie nisi in quo $\mathrm{Be}$

As $B e$ shares all accidents of $S g$ and adds its own ones, it is likely that it derives from $S g$. 


\section{Stemma Codicum and Manuscripts Chosen for the Edition}

In light of all of these considerations, we can propose the following stemma codicum:

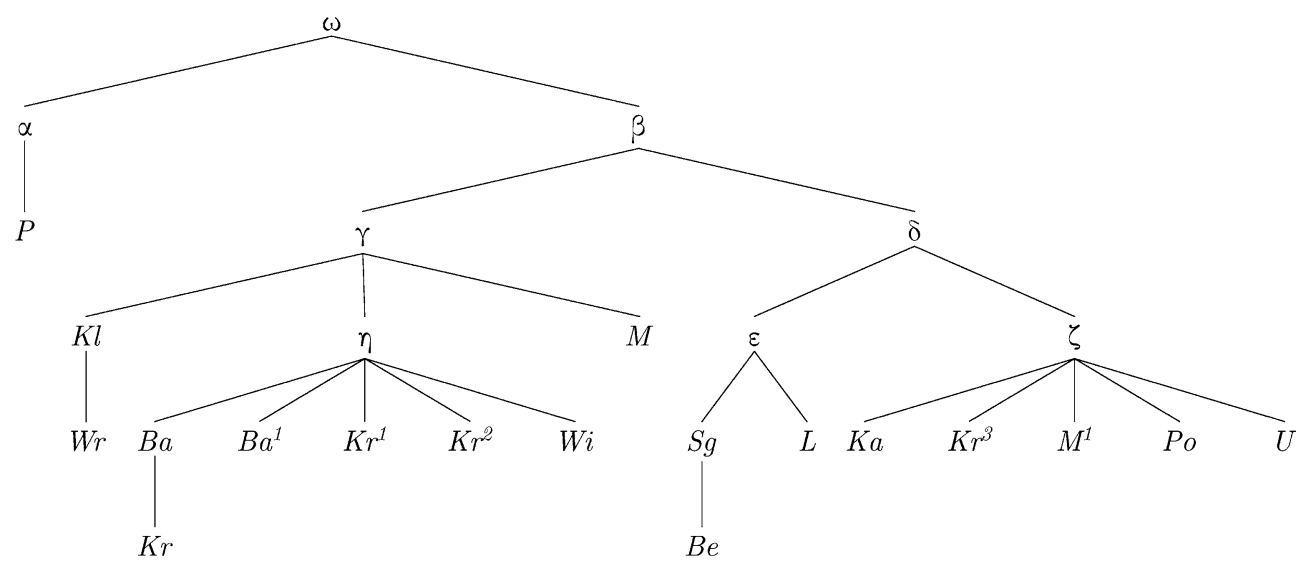

As a result of the study of the manuscript tradition of the second redaction of Oresme's Questions on Meteorology, I chose $P$ as the base text and $B a, K l, L$, and $U$ as representatives of the different groups of family $\beta$. The collation has shown that within their groups, these manuscripts have relatively few accidents not shared by the whole family.

\section{Location of the Questions in the Manuscripts}

The following list indicates the place of each question in the manuscripts transmitting the second redaction of Oresme's Questions on Meteorology. Its aim is to help scholars working directly with one of these codices to quickly locate specific passages in Oresme's text.

I.1 Utrum possibile sit de impressionibus metheorologicis habere simul scientiam et opinionem

$B a 4^{\text {ra }} B a_{1} 2^{\text {ra }} B e 39^{\text {r } K a 2^{\text {ra }} K l^{\text {ra }} K r} 59^{\text {va }} K_{1} 3^{\text {ra }} K r_{2} 245^{\text {ra }} K r_{3} 195^{\text {ra }} L 181^{\text {ra }} M 1^{\text {ra }} P$ $226^{\mathrm{r}} P O 1^{\text {ra }} S g 1^{\mathrm{r}} U 2^{\text {ra }} W i 49^{\text {ra }} W r 1^{\mathrm{r}}$

I.2 Utrum impressiones metheorologice fiant secundum naturam inordinatiorem quam sit natura celi

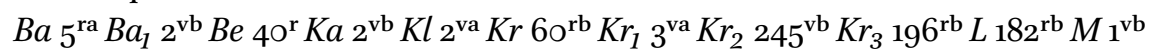
$P 227^{\mathrm{v}} \mathrm{Po}_{2^{\text {rb }}} \mathrm{Sg} 3^{\mathrm{r} U} 3^{\text {ra }} \mathrm{Wi} 49^{\mathrm{va}} \mathrm{Wr} 2^{\mathrm{v}}$ 
I.3 Utrum iste mundus inferior sit continuus lationibus superioribus ut virtus eius inde gubernetur

$\mathrm{Ba} 5^{\text {vb }} \mathrm{Ba} a_{1} 3^{\mathrm{ra}} \mathrm{Be} 41^{\mathrm{r}} \mathrm{Ka} 4^{\mathrm{ra}} \mathrm{Kl} 4^{\mathrm{ra}} \mathrm{Kr} 61^{\mathrm{va}} \mathrm{Kr}_{1} 4^{\mathrm{ra}} \mathrm{Kr}_{2} 246^{\text {vb }} \mathrm{Kr}_{3} 197^{\mathrm{rb}} \mathrm{L} 183^{\text {va }} \mathrm{M}^{\text {va }} \mathrm{P}$ $228^{\mathrm{v}} \mathrm{Po} 3^{\mathrm{vb}} \mathrm{Sg} 3^{\mathrm{v}} \mathrm{U}_{4}^{\mathrm{rb}} \mathrm{Wi} 5^{\mathrm{O}^{\mathrm{ra}} \mathrm{Wr} 4^{\mathrm{v}}}$

I.4 Utrum, cessante motu celi, cessarent motus in isto mundo inferiori $\mathrm{Ba} 7^{\mathrm{rb}} \mathrm{Ba}{ }_{1} 4^{\mathrm{va}} \mathrm{Be} 4^{\mathrm{r}} \mathrm{Ka} 5^{\mathrm{rb}} \mathrm{Kl} 6^{\mathrm{ra}} K r 61^{\mathrm{ra}} K r_{1} 4^{\mathrm{vb}} K r_{2} 248^{\mathrm{ra}} K r_{3} 199^{\mathrm{ra}} L{ }_{18} 5^{\mathrm{rb}} M 3^{\text {va } P}$ $230^{\mathrm{v}} \mathrm{Po} 5^{\mathrm{va}} S g 7^{\mathrm{v}} U 5^{\mathrm{vb}} W i 5^{1^{\mathrm{ra}} W r} 7^{\mathrm{v}}$

I.5 Utrum eedem opiniones infinities reiterentur

$\mathrm{Ba} 8^{\mathrm{rb}} \mathrm{Ba} 5_{1} 5^{\mathrm{ra}} \mathrm{Be} 43^{\mathrm{r}} \mathrm{Ka} 6^{\mathrm{ra}} \mathrm{Kl} 7^{\mathrm{ra}} K r 61^{\mathrm{rb}} K r_{1} 5^{\mathrm{rb}} \mathrm{Kr}_{2} 248^{\mathrm{rb}} K r_{3} 200^{\mathrm{ra}} L 1^{8} 6^{\mathrm{ra}} M 4^{\mathrm{ra}}$ $P 22^{\mathrm{r}} P o 6^{\text {va }} S g 9^{\mathrm{r}} U 6^{\mathrm{va}} W i 5^{{ }^{\mathrm{va}}} W r 8^{\mathrm{v}}$

I.6 Utrum elementa sint continue proportionalia ad invicem

$B a 9^{\mathrm{rb}} \mathrm{Ba} a_{1} 5^{\mathrm{vb}} \mathrm{Be} 43^{\mathrm{v}} K a 7^{\mathrm{ra}} K l 8^{\mathrm{vb}} K r 61^{\mathrm{vb}} K r_{1} 5^{\mathrm{vb}} K_{2} 249^{\mathrm{vb}} K r_{3} 2{ }^{\mathrm{O}}{ }^{\mathrm{rb}} L 1^{8} 7^{\mathrm{rb}} M 4^{\mathrm{vb}}$ $P 233^{\mathrm{v}} \mathrm{Po} 7^{\mathrm{rb}} \operatorname{Sg} 1^{\mathrm{r}} U 7^{\mathrm{va}} W i 5^{2^{\mathrm{ra}}} W r 10^{\mathrm{v}}$

I.7 Utrum quatuor elementa semper et immutabiliter habeant eandem proportionem ad invicem

$\mathrm{Ba} 11^{\mathrm{ra}} \mathrm{Ba} 7_{1} 7^{\mathrm{ra}} \mathrm{Be} 45^{\mathrm{r}} K a 8^{\mathrm{vb}} K l 1^{\mathrm{rb}} K r 62^{\mathrm{vb}} K r_{1} 6^{\mathrm{vb}} K r_{2} 25^{\mathrm{ra}} K r_{3} 203^{\mathrm{rb}} L 1^{8} 9^{\mathrm{ra}} M 5^{\mathrm{vb}}$ $P 235^{\mathrm{v}} \mathrm{Po} 10^{\mathrm{rb}} \mathrm{Sg} 14^{\mathrm{v}} U 9^{\mathrm{rb}} W i 53^{\mathrm{ra}} W r 14^{\mathrm{r}}$

I.8 Utrum motus celi sit causa calefactionis ignis in sua spera et etiam aeris superioris

$\mathrm{Ba} 12^{\mathrm{ra}} \mathrm{Ba} a_{1} 7^{\mathrm{vb}} \mathrm{Be} 4^{\mathrm{r}} \mathrm{Ka} 9^{\mathrm{va}} K l 1^{\mathrm{va}} K r 63^{\mathrm{ra}} K r_{1} 7^{\mathrm{rb}} K r_{2} 25^{\mathrm{vb}} K r_{3} 204^{\mathrm{va}} / 207^{\mathrm{v73}} L$ $190^{\text {ra }} M 6^{\text {va }} P 237^{\mathrm{r}} P o 1^{\text {va }} S g 16^{\mathrm{v}} U 10^{\mathrm{rb}} W i 53^{\mathrm{vb}} W r 15^{\mathrm{v}}$

I.9 Utrum lumen sit productivum caloris

$B a 13^{\mathrm{va}} B a_{1} 8^{\mathrm{vb}} B e 47^{\mathrm{r}} K a 1^{\mathrm{ra}} K l 13^{\mathrm{va}} K r 63^{\mathrm{vb}} K r_{1} 8^{\mathrm{ra}} K r_{2} 253^{\mathrm{ra}} K r_{3} 206^{\mathrm{ra}} / 208^{\mathrm{v}} L 191^{\mathrm{va}}$ $M 7^{\text {ra } P} 23^{\text {v }}$ Po $13^{\text {ra }} S g 18^{\text {v }} U 11^{\text {va }} W i 54^{\text {vb } W r} 18^{\text {v }}$

I.10 Utrum contrarium circumstans suum contrarium fortificet ipsum

$\mathrm{Ba} 14^{\mathrm{vb}} \mathrm{Ba} a_{1} 9^{\mathrm{va}} \mathrm{Be} 4^{\mathrm{r}} \mathrm{Ka} 12^{\mathrm{rb}} \mathrm{Kl} 16^{\mathrm{va}} K r 64^{\mathrm{rb}} K r_{1} 8^{\mathrm{vb}} K_{2} 254^{\mathrm{ra}} K r_{3} 209^{\mathrm{v}} L 191^{\text {vb }} M$ $8^{\text {ra }} \mathrm{P} 240^{\mathrm{r}} \mathrm{Po} 14^{\mathrm{va}} \mathrm{Sg} 21^{\mathrm{v}} U 13^{\mathrm{ra}} \mathrm{Wi} 55^{\mathrm{va}} \mathrm{Wr} 2 \mathrm{O}^{\mathrm{v}}$

73 This question and the following one can be found twice in this codex. See above the description of this manuscript. 
I.11 Utrum semper media regio aeris sit frigida

$B a{ }_{1} 6^{\text {rb }} B a_{1} 10^{\text {va }} B e 49^{\mathrm{r}} K a 13^{\text {vb }} K l_{1} 8^{\mathrm{va}} K r 65^{\text {ra }} K r_{1} 9^{\text {va }} K r_{2} 25^{6^{\mathrm{ra}}} K_{3} 211^{\mathrm{r}} L 194^{\mathrm{ra}} M 9^{\mathrm{ra}}$ $P 241^{\mathrm{v}}$ Po $16^{\mathrm{rb}} S g 24^{\mathrm{r}} U 14^{\mathrm{rb}} W i 5^{\text {va }} W r 23^{\mathrm{r}}$

I.12 Utrum omnium impressionum metheorologicarum vapor et exalatio sint principium materiale

$B a 18^{\text {va }} B a_{1} 1^{\text {va }} B e 5^{0^{\mathrm{v}}} K a 16^{\text {ra }} K l 21^{\text {va }} K r 65^{\text {vb }} K r_{1} 10^{\text {va }} K r_{2} 258^{\text {ra }} K r_{3} 213^{\text {r }} L 196^{\text {ra }} M$ $10^{\mathrm{va}} \mathrm{P} 244^{\mathrm{r}} \mathrm{Po} 19^{\mathrm{rb}} \mathrm{Sg} 28^{\mathrm{r}} U 16^{\mathrm{rb}} W i 57^{\mathrm{vb}} W r 27^{\mathrm{r}}$

I.13 Utrum impressiones ignite, seu ille que fiunt per inflammationem, fiant naturaliter in aere

$\mathrm{Ba} 19^{\mathrm{va}} \mathrm{Ba} a_{1} 12^{\mathrm{rb}} \mathrm{Be} 5^{2^{\mathrm{r}}} \mathrm{Ka} 17^{\mathrm{va}} K l 23^{\mathrm{rb}} K r 66^{\mathrm{va}} K r_{1} 1^{\text {ra }} K r_{2} 259^{\mathrm{ra}} K r_{3} 214^{\mathrm{v}} L 197^{\mathrm{ra}} M$

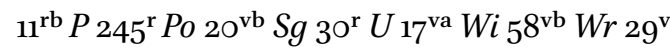

I.14 Utrum de nocte, serenitate existente, debeant apparere hyatus et voragines et sanguinei colores in celo

$\mathrm{Ba} 2 \mathrm{O}^{\mathrm{vb}} \mathrm{Ba} a_{1} 12^{\mathrm{vb}} \mathrm{Be} 5^{2^{\mathrm{v}}} K a 18^{\mathrm{va}} K \mathrm{~L}_{2} 5^{\mathrm{vb}} K r 66^{\mathrm{vb}} K r_{1} 1^{\mathrm{vb}} K r_{2} 259^{\mathrm{vb}} K r_{3} 215^{\mathrm{r}} L 197^{\mathrm{vb}} M$ ${ }_{11}^{\mathrm{vb}} P 246^{\mathrm{r}} \mathrm{Po} 22^{\mathrm{ra}} S g 31^{\mathrm{v}} U 18^{\mathrm{rb}} W i 59^{\mathrm{rb}} W r 31^{\mathrm{r}}$

I.15 Utrum cometa sit de natura celi vel elementari

$B a 21^{\text {va }} B a_{1} 1^{\text {va }} B e 53^{\text {v }} K a 19^{\text {va }} K l 26^{\text {ra }} K r 67^{\text {rb }} K r_{1} 12^{\text {ra }} K r_{2} 260^{\text {va }} K r_{3}{ }_{21} 6^{\text {r }} L 198^{\text {va }} M$ $12^{\mathrm{va}} \mathrm{P} 247^{\mathrm{r}} \mathrm{Po} 23^{\mathrm{rb}} \mathrm{Sg} 33^{\mathrm{r}} U 19^{\mathrm{rb}}$ Wi $60^{\mathrm{ra}} \mathrm{Wr} 32^{\mathrm{v}}$

I.16 Utrum cometa sit exalatio calida et inflammata

$\mathrm{Ba} 22^{\mathrm{vb}} \mathrm{Ba} a_{1} 14^{\mathrm{rb}} \mathrm{Be} 54^{\mathrm{v}} \mathrm{Ka} 2 \mathrm{O}^{\mathrm{va}} \mathrm{Kl} 27^{\mathrm{vb}} \mathrm{Kr} 67^{\mathrm{vb}} \mathrm{Kr}_{1} 12^{\mathrm{vb}} \mathrm{Kr}_{2} 261^{\mathrm{va}} \mathrm{Kr}_{3} 217^{\mathrm{r}} L 199^{\mathrm{va}} M$ ${ }_{13}{ }^{\mathrm{ra}} \mathrm{P} 248^{\mathrm{v}} \mathrm{Po} 24^{\mathrm{vb}} \mathrm{Sg} 35^{\mathrm{r}} U 2^{\mathrm{rb}} W i 60^{\mathrm{vb}} \mathrm{Wr} 34^{\mathrm{v}}$

I.17 Utrum motus comete sit naturalis vel violentus

$B a 23^{\text {va }} B a_{1} 14^{\text {vb }} B e 55^{\mathrm{r}} K a 21^{\mathrm{rb}} K l 28^{\mathrm{vb}} K r 68^{\mathrm{ra}} K r_{1} 13^{\mathrm{ra}} K r_{2} 262^{\mathrm{rb}} K r_{3}{ }_{21} 8^{\mathrm{r}} L 200^{\mathrm{rb}} M$

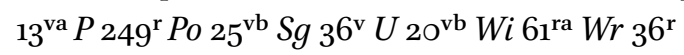

I.18 Utrum comete significent mortem principum, siccitatem et ventos et motus terre

$\mathrm{Ba} 24^{\mathrm{ra}} \mathrm{Ba} 15^{\mathrm{rb}} \mathrm{Be} 5^{6^{\mathrm{r}}} \mathrm{Ka} 22^{\mathrm{rb}} K l 3^{\mathrm{O}} \mathrm{Kr}^{\mathrm{ra}} 68^{\mathrm{va}} \mathrm{Kr}_{1} 13^{\mathrm{va}} K r_{2} 263^{\mathrm{ra}} \mathrm{Kr}_{3} 255^{\mathrm{r}} L 2 \mathrm{O} 1^{\mathrm{rb}} M$ $14^{\mathrm{rb}} P 25^{\mathrm{r}} \mathrm{Po} 26^{\mathrm{vb}} S g 3^{\mathrm{r}} U 21^{\mathrm{va}} W i 61^{\mathrm{vb}} W r 37^{\mathrm{r}}$

I.19 Utrum galaxia sit de natura celi vel de natura elementari

$\mathrm{Ba} 25^{\mathrm{ra}} \mathrm{Ba} a_{1} 5^{\mathrm{vb}} \mathrm{Be} 5^{6^{\mathrm{v}}} \mathrm{Ka} 23^{\mathrm{ra}} K l_{31^{\mathrm{rb}}} \mathrm{Kr} 69^{\mathrm{ra}} K_{1} 14^{\mathrm{ra}} K r_{2} 263^{\mathrm{vb}} K r_{3} 2^{255^{\mathrm{v}} L} 2 \mathrm{O} 2^{\mathrm{rb}} M$ ${ }_{14}{ }^{\mathrm{vb}} P 25^{1^{\mathrm{r}}} P o 27^{\mathrm{vb}} S g 39^{\mathrm{v}} U 22^{\mathrm{va}} W i 62^{\mathrm{rb}} W r 3^{\mathrm{v}}$ 
II.1 Utrum locus generationis pluvie sit media regio aeris

$\mathrm{Ba} 26^{\mathrm{vb}} \mathrm{Ba}{ }_{1} 1^{\mathrm{ra}} \mathrm{Be} 5^{8^{\mathrm{v}}} \mathrm{Ka} 25^{\mathrm{ra}} K l_{33^{\mathrm{rb}}}^{\mathrm{rb}} 69^{\mathrm{vb}} K r_{1} 14^{\mathrm{rb}} K r_{2} 265^{\mathrm{ra}} K r_{3} 257^{\mathrm{v}} L 23^{\mathrm{vb}} M$ ${ }_{1}{ }^{\mathrm{vb}} \mathrm{P} 253^{\mathrm{v}} \mathrm{Po} 29^{\mathrm{vb}} \mathrm{Sg} 4^{\mathrm{v}} U 24^{\mathrm{ra}} W i 63^{\mathrm{rb}} W r 41^{\mathrm{v}}$

II.2 Utrum ros et pruina, nix et pluvia, sint eiusdem speciei

$\mathrm{Ba} 28^{\mathrm{ra}} \mathrm{Ba} a_{1} 7^{\mathrm{vb}} \mathrm{Be} 59^{\mathrm{v}} \mathrm{Ka} 26^{\mathrm{rb}} \mathrm{Kl} 35^{\mathrm{rb}} \mathrm{Kr} 7 \mathrm{O}^{\mathrm{rb}} K r_{1} 15^{\mathrm{va}} \mathrm{Kr}_{2} 266^{\mathrm{rb}} \mathrm{Kr}_{3} 259^{\mathrm{ra}} L_{20} 5^{\mathrm{ra}}$ $M 16^{\mathrm{vb}} P 254^{\mathrm{r}} \mathrm{Po} 3^{\mathrm{rb}} \mathrm{Sg} 44^{\mathrm{v}} U 25^{\mathrm{ra}} \mathrm{Wi} 64^{\mathrm{ra}} W r 43^{\mathrm{v}}$

II.3 Utrum grandines magis debeant generari in hieme quam in autumno

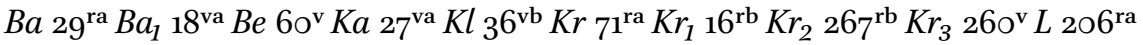
$M 17^{\text {va }} P 25^{\text {v }} P o 2^{\text {vb }} S g 4^{\mathrm{r}} U 26^{\mathrm{rb}} W i 64^{\mathrm{vb}} W r 45^{\mathrm{v}}$

II.4 Utrum aqua calida applicata frigori congelanti citius congeletur quam aqua frigida

$\mathrm{Ba} 3 \mathrm{O}^{\mathrm{rb}} \mathrm{Ba} a_{1} 9^{\mathrm{va}} \mathrm{Be} 61^{\mathrm{v}} \mathrm{Ka} 28^{\mathrm{vb}} K l_{3} 8^{\mathrm{rb}} K r 7^{\mathrm{va}} K r_{1} 16^{\mathrm{vb}} K r_{2} 268^{\mathrm{va}} K_{3} 262^{\mathrm{r}} L 207^{\mathrm{ra}} M$ $1^{\mathrm{rb}} \mathrm{P} 257^{\mathrm{v}} \mathrm{Po} 34^{\mathrm{ra}} \mathrm{Sg} 49^{\mathrm{r}} U 27^{\mathrm{rb}} W i 65^{\mathrm{va}} \mathrm{Wr} 47^{\mathrm{v}}$

II.5 Utrum rubedo matutina sit signum pluvie

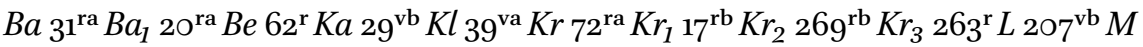
${ }^{18^{\mathrm{vb}} P} 25^{\mathrm{v}} \mathrm{Po} 35^{\mathrm{rb}} \mathrm{Sg} 5^{\mathrm{O}^{\mathrm{v}}} U 28^{\mathrm{ra}} W i 66^{\mathrm{ra}} W r 49^{\mathrm{r}}$

II. 6 Utrum caligo sit signum pluvie future

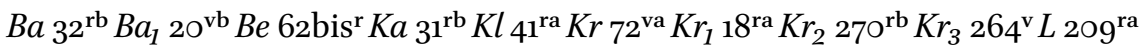
$M 19^{\mathrm{vb}} P{ }_{26} \mathrm{o}^{\mathrm{r}} \mathrm{Po} 3^{6^{\mathrm{va}}} \mathrm{Sg} 53^{\mathrm{r}} U 29^{\mathrm{rb}} W i 66^{\mathrm{vb}} W r 5^{\mathrm{r}}$

II.7 Utrum aqua naturaliter ascendat ad orificia fontium

$\mathrm{Ba} 33^{\mathrm{ra}} \mathrm{Ba} a_{1} 2^{\mathrm{rb}} \mathrm{Be} 62 \mathrm{bis}^{\mathrm{v}} \mathrm{Ka} 3^{2^{\mathrm{ra}}} \mathrm{Kl} 41^{\mathrm{vb}} K r 3^{\mathrm{ra}} \mathrm{Kr}_{1} 1^{\mathrm{va}} K r_{2} 271^{\mathrm{ra}} K r_{3} 2^{26} 5^{\mathrm{v}} L 209^{\mathrm{vb}}$ $M 2{ }^{\mathrm{rb}} P{ }_{26}{ }^{\mathrm{r}} P o 3^{8^{\mathrm{rb}}} S g 4^{\mathrm{r}} U 29^{\mathrm{vb}} W i 67^{\mathrm{rb}} W r 5^{2^{\mathrm{v}}}$

II.8 Utrum aque fontium generentur in terra

$\mathrm{Ba} 33^{\mathrm{vb}} \mathrm{Ba} a_{1} 2^{\mathrm{vb}} \mathrm{Be} 63^{\mathrm{v}} \mathrm{Ka} 33^{\mathrm{ra}} \mathrm{Kl} 43^{\mathrm{ra}} \mathrm{Kr} 73^{\mathrm{rb}} K r_{1} 19^{\mathrm{ra}} K r_{2} 271^{\mathrm{vb}} K r_{3} 266^{\mathrm{v}} L 210^{\mathrm{va}} M$ ${ }_{2}{ }^{\mathrm{vb}} \mathrm{P} 262^{\mathrm{r}} \mathrm{Po} 39^{\mathrm{vb}} S g 55^{\mathrm{v}} U 30^{\mathrm{va}} W i 67^{\mathrm{vb}} W r 54^{\mathrm{r}}$

II.9 Utrum mare sit perpetuum vel aliquando fuit factum

$\mathrm{Ba} 35^{\mathrm{ra}} \mathrm{Ba} a_{1} 2^{\mathrm{va}} \mathrm{Be} 64^{\mathrm{v}} \mathrm{Ka} 34^{\mathrm{rb}} \mathrm{Kl} 44^{\mathrm{va}} \mathrm{Kr} 74^{\mathrm{ra}} \mathrm{Kr}_{1} 19^{\mathrm{vb}} \mathrm{Kr}_{2} 22^{\mathrm{vb}} K r_{3} 244^{\mathrm{r}} L 211^{\mathrm{vb}} M$ ${ }_{21} 1^{\text {va }} P 263^{\text {v }} P o 4^{\text {ra }} S g 5^{8^{\mathrm{r}} U} 3^{1^{\mathrm{vb}} W i 68^{\mathrm{va}} W r} 5^{6^{\mathrm{r}}}$

II.10 Utrum mare debeat fluere et refluere

$\mathrm{Ba} 3^{6^{\mathrm{rb}} \mathrm{Ba}} a_{1} 3^{\mathrm{va}} \mathrm{Be} 65^{\mathrm{v}} \mathrm{Ka} 35^{\mathrm{vb}} \mathrm{Kl} 46^{\mathrm{ra}} \mathrm{Kr} 74^{\mathrm{vb}} \mathrm{Kr}_{1} 2 \mathrm{O}^{\mathrm{va}} \mathrm{Kr}_{2} 274^{\mathrm{ra}} \mathrm{Kr}_{3} 245^{\mathrm{v}} L 213^{\mathrm{ra}} \mathrm{M}$ ${ }_{22}{ }^{\mathrm{rb}} \mathrm{P} 265^{\mathrm{r}} \mathrm{Po} 4^{\mathrm{ra}} \mathrm{Sg} 60^{\mathrm{r}} U 33^{\mathrm{ra}} W i 69^{\mathrm{rb}} W r 5^{8^{\mathrm{v}}}$ 
II.11 Utrum aqua maris debeat esse salsa

$\mathrm{Ba} 37^{\mathrm{vb}} \mathrm{Ba}_{1} 24^{\mathrm{va}} \mathrm{Be} 67^{\mathrm{r}} \mathrm{Ka} 37^{\mathrm{rb}} K \mathrm{Kl}_{4} 8^{\mathrm{ra}} \mathrm{Kr}_{7} 5^{\mathrm{va}} \mathrm{Kr}_{1} 21^{\mathrm{ra}} \mathrm{Kr}_{2} 275^{\mathrm{rb}} \mathrm{Kr}_{3} 247^{\mathrm{v}} L 214^{\mathrm{vb}} M$ ${ }_{23^{\mathrm{rb}} \mathrm{Po}}^{\mathrm{r}} 4^{\mathrm{vb}} \mathrm{Sg} 63^{\mathrm{r}} U 34^{\mathrm{rb}} W i 7^{\mathrm{rb}} \mathrm{Wr} 61^{\mathrm{r}}$

II.12 Utrum aque puteales debeant esse salse

$\mathrm{Ba} 39^{\mathrm{ra}} \mathrm{Ba}_{1} 25^{\text {rb }} \mathrm{Be} 68^{\mathrm{r}} \mathrm{Ka} 3^{8^{\mathrm{vb}}} \mathrm{Kl} 4^{\mathrm{vb}} \mathrm{Kr}_{7} 6^{\mathrm{ra}} \mathrm{Kr}_{1} 22^{\text {ra }} \mathrm{Kr}_{2} 27^{\mathrm{ra}} \mathrm{Kr}_{3} 249^{\mathrm{r}} L 216^{\mathrm{ra}} M$ $24^{\mathrm{rb}} \mathrm{Po} 44^{\mathrm{rb}} \mathrm{Sg} 65^{\mathrm{v}} U 45^{\mathrm{va}} \mathrm{Wi} 7^{\mathrm{rb}} \mathrm{Wr} 63^{\mathrm{v}}$

III.1 Utrum ventus sit exalatio calida et sicca

$\mathrm{Ba} 4 \mathrm{O}^{\mathrm{ra}} \mathrm{Ba}_{1} 2^{\mathrm{vb}} \mathrm{Be} 69^{\mathrm{r}} \mathrm{Ka} 39^{\mathrm{vb}} \mathrm{Kl} 5_{\mathrm{O}^{\mathrm{va}}} \mathrm{Kr}_{7} 6^{\mathrm{va}} \mathrm{Kr}_{1} 2^{\mathrm{va}} \mathrm{Kr}_{2} 2{ }_{2} 6^{\mathrm{vb}} \mathrm{Kr}_{3} 25^{\mathrm{r}} L 216^{\mathrm{vb}}$ $M 24^{\text {vb }} P o 45^{\text {ra }} S g 67^{\text {r } U} 3^{6^{\mathrm{ra}}} W i 7^{\mathrm{vb}} W r 64^{\mathrm{v}}$

III.2 Utrum Sol faciat cessare ventos et moveat eos

$\mathrm{Ba} 44^{\text {ra }} \mathrm{Ba}_{1} 26^{\text {vb }} \mathrm{Be} 69^{\mathrm{v}} \mathrm{Ka} 41^{\text {ra }} \mathrm{Kl} 5_{2^{\text {ra }}} \mathrm{Kr} 77^{\text {ra }} \mathrm{Kr}_{1} 23^{\text {ra }} \mathrm{Kr}_{2} 277^{\text {va }} \mathrm{Kr}_{3} 2^{21^{\mathrm{v}} L} 218^{\text {ra }} M$ $25^{\text {va }} \mathrm{Po} 46^{\text {rb }} S g 69^{\text {r }} U 37^{\text {ra }} W i 7^{\text {rb }} W r 66^{\text {v }}$

III.3 Utrum Boreas veniat a polo artico et Auster a polo antartico

$\mathrm{Ba} 44^{\mathrm{vb}} \mathrm{Ba}_{1} 27^{\text {rb }} \mathrm{Be} 7 \mathrm{O}^{\mathrm{v}} \mathrm{Ka} 42^{\mathrm{ra}} \mathrm{Kl} 53^{\text {ra }} \mathrm{Kr} 77^{\text {va }} \mathrm{Kr}_{1} 23^{\mathrm{va}} \mathrm{Kr}_{2} 27^{8^{\mathrm{rb}}} \mathrm{Kr}_{3} 25^{2^{\mathrm{v}}} L 218^{\mathrm{vb}} \mathrm{M}$ ${ }_{2} 6^{\mathrm{ra}} \mathrm{Po} 47^{\mathrm{rb}} \mathrm{Sg} 7^{\mathrm{v}} U 37^{\mathrm{vb}} \mathrm{Wi} 7^{\mathrm{vb}} \mathrm{Wr} 68^{\mathrm{v}}$

III.4 Utrum motus terre sit possibilis

$\mathrm{Ba} 42^{\mathrm{vb}} \mathrm{Ba}_{1} 2^{8^{\mathrm{ra}} \mathrm{Be}} 71^{\mathrm{v}} \mathrm{Ka} 43^{\mathrm{rb}} \mathrm{Kl} 54^{\mathrm{va}} \mathrm{Kr}_{7} 8^{\mathrm{ra}} \mathrm{Kr}_{1} 24^{\mathrm{ra}} \mathrm{Kr}_{2} 279^{\mathrm{rb}} \mathrm{Kr}_{3} 254^{\mathrm{r}} L 219^{\mathrm{vb}} \mathrm{M}$ ${ }_{2} 6^{\text {vb }} \mathrm{Po} 48^{\mathrm{va}} S g 7^{\mathrm{r}} U_{3} 8^{\mathrm{vb}} \mathrm{Wi} 73^{\mathrm{va}} \mathrm{Wr} 7 \mathrm{O}^{\mathrm{r}}$

III.5 Utrum tranquillitas sit signum terre motus

$\mathrm{Ba} 44^{\text {ra }} \mathrm{Ba}_{1} 29^{\mathrm{ra}} \mathrm{Be} 72^{\mathrm{v}} \mathrm{Ka} 44^{\mathrm{va}} \mathrm{Kl} 55^{\mathrm{ra}} \mathrm{Kr} 78^{\mathrm{vb}} \mathrm{Kr}_{1} 24^{\mathrm{vb}} \mathrm{Kr}_{2} 280^{\mathrm{rb}} \mathrm{Kr}_{3} 200^{\mathrm{r}} L 220^{\mathrm{vb}}$ $M 27^{\text {va }} P o 5^{\text {ra }} S g 4^{\text {v }} U 40^{\text {ra }} W i 74^{\text {va }} W r 72^{\text {v }}$

III.6 Utrum tonitruum sit extinctio ignis in nube

$\mathrm{Ba} 44^{\mathrm{vb}} \mathrm{Ba} a_{1} 2^{\mathrm{vb}} \mathrm{Be} 73^{\mathrm{r}} K a 45^{\mathrm{vb}} K l_{5} 7^{\mathrm{rb}} K r 79^{\mathrm{rb}} K r_{1} 25^{\mathrm{rb}} K r_{2} 281^{\mathrm{ra}} K r_{3} 221^{\mathrm{v}} L 221^{\mathrm{vb}} M$ $28^{\text {rb }} P_{5} 1^{\text {ra }} S g 7^{\text {r }} U 4^{\text {vb }} W i 75^{\text {rb }} W r 74^{\mathrm{v}}$

III.7 Utrum exalatio ex qua fiunt tonitrua et corruscationes debeat descendere versus terram

$\mathrm{Ba} 46^{\mathrm{rb}} \mathrm{Ba} a_{1} \mathrm{O}^{\mathrm{vb}} \mathrm{Be} 74^{\mathrm{r}} \mathrm{Ka} 47^{\mathrm{ra}} \mathrm{Kl} 5^{8^{\mathrm{vb}}} \mathrm{Kr} 80^{\text {ra }} \mathrm{Kr}_{1} 26^{\text {ra }} \mathrm{Kr}_{2} 282^{\text {ra }} \mathrm{Kr}_{3} 222^{\mathrm{v}} L 223^{\text {ra }}$ $M 29^{\text {ra }} P_{0} 5^{2^{\text {va }}} S g 7^{\mathrm{v}} U 4^{\mathrm{vb}} W i 7^{6^{\mathrm{ra}}} W r 7^{\mathrm{r}}$

III.8 Utrum corruscatio sit possibilis

$\mathrm{Ba} 47^{\mathrm{ra}} \mathrm{Ba}_{1} 3^{\mathrm{1}^{\mathrm{vb}}} \mathrm{Be} 75^{\mathrm{r}} \mathrm{Ka} 48^{\mathrm{rb}} \mathrm{Kl} 6 \mathrm{o}^{\mathrm{ra}} \mathrm{Kr} 8 \mathrm{O}^{\mathrm{va}} \mathrm{Kr}_{1} 26^{\mathrm{va}} \mathrm{Kr}_{2} 282^{\mathrm{vb}} \mathrm{Kr}_{3} 225^{\mathrm{r}} L 224^{\text {ra }}$ $M 29^{\text {va }} P o 53^{\text {vb }} S g 81^{\mathrm{r}} U 4^{\text {vb }} W i 7^{\text {vb }} W r 7^{\text {r }}$ 
III.9 Utrum fulmen aliquod sit penetrans et aliud adurens

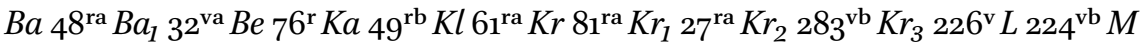
$30^{\text {rb }}$ Po $54^{\text {vb }} \mathrm{Sg} 83^{\text {r }} U 43^{\text {va }} W i 77^{\text {rb }} W r 79^{\text {v }}$

III.1O Utrum indifferenter quodlibet posset percuti fulmine

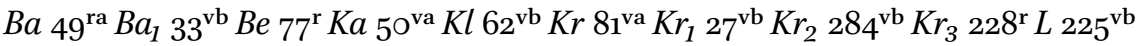
$M 3^{\mathrm{ra}} \mathrm{Po} 5^{6^{\mathrm{rb}}} S g 85^{\mathrm{r}} U 44^{\mathrm{vb}} W i 8^{\mathrm{rb}} \mathrm{Wr} 80^{\mathrm{v}}$

III.11 Utrum tiphon et ecnephia et incensio sint exalationes calide et sicce $\mathrm{Ba} 49^{\text {va }} \mathrm{Ba} a_{1} 34^{\text {ra }} \mathrm{Be} 77^{\mathrm{r}} \mathrm{Ka} 5^{\text {ra }} K l 63^{\text {rb }} K r 81^{\text {vb }} \mathrm{Kr}_{1} 28^{\text {ra }} \mathrm{Kr}_{2} 285^{\text {ra }} \mathrm{Kr}_{3} 229^{\mathrm{r}} L 226^{\text {rb }} M$ $3^{1^{\mathrm{rb}} \mathrm{Po}} 57^{\mathrm{ra}} \mathrm{Sg} 86^{\mathrm{r}} U 45^{\mathrm{ra}} \mathrm{Wi} 7^{\mathrm{vb}} \mathrm{Wr} 82^{\mathrm{r}}$

III.12 Utrum visus frangatur in occursu medii densioris vel rarioris, puta aque vel aeris

$\mathrm{Ba} 5^{\mathrm{o}^{\mathrm{rb}}} \mathrm{Ba} a_{1} 34^{\mathrm{vb}} \mathrm{Be} 7^{\mathrm{r}} \mathrm{Ka} 5^{2^{\mathrm{ra}}} K l 64^{\mathrm{rb}} \mathrm{Kr} 82^{\mathrm{rb}} \mathrm{Kr}_{1} 28^{\mathrm{va}} \mathrm{Kr}_{2} 285^{\mathrm{vb}} \mathrm{Kr}_{3} 23^{\mathrm{O}^{\mathrm{r}}} L 227^{\mathrm{ra}}$ $M_{32^{\mathrm{ra}}} \mathrm{Po} 5^{\mathrm{vb}} \mathrm{Sg} 87^{\mathrm{v}} U 45^{\mathrm{vb}} W i 79^{\mathrm{rb}} \mathrm{Wr} 83^{\mathrm{v}}$

III.13 Utrum cuiuslibet corporis superficies reflectat virtutes super ipsam incidentes, sicut sunt lumen, species coloris et huiusmodi

$\mathrm{Ba} 5^{2^{\text {ra }}} \mathrm{Ba}_{1} 3^{\text {vb }} \mathrm{Be} 79^{\mathrm{v}} \mathrm{Ka} 54^{\text {ra }} \mathrm{Kl} 66^{\mathrm{vb}} \mathrm{Kr} 83^{\text {va }} \mathrm{Kr}_{1} 29^{\mathrm{va}} \mathrm{Kr}_{2} 287^{\text {vb }} \mathrm{Kr}_{3} 233^{\mathrm{r}} L 229^{\text {ra }}$ $M 33^{\text {rb }} \mathrm{Po} 6 \mathrm{o}^{\mathrm{rb}} \mathrm{Sg} 91^{\mathrm{v}} U 47^{\mathrm{va}}$ Wi $80^{\mathrm{vb}}$ Wr $87^{\mathrm{r}}$

III.14 Utrum virtutes reflexe sint debiliores virtutibus non reflexis

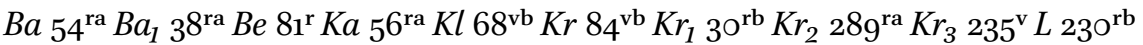
$M 34^{\mathrm{rb}} \mathrm{Po} 61^{\mathrm{vb}} \mathrm{Sg} 94^{\mathrm{v}} U 4^{\mathrm{vb}} W i 8^{\mathrm{vb}} W r 89^{\mathrm{v}}$

III.15 Utrum aliqua specula representent solum colorem et non figuram, accipiendo 'colorem' prout extendit se ad lucem et ad colorem proprie dictum

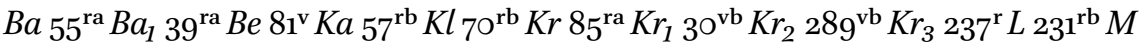
$35^{\text {ra }} \mathrm{Po} 63^{\text {rb }} S g 9^{\text {v }} U 49^{\text {vb }} W i 82^{\text {va }} W r 91^{\mathrm{r}}$

III.16 Utrum in apparitione ipsius halonis interponatur vapor inter visum et astrum

$\mathrm{Ba} 5^{6^{\mathrm{va}}} \mathrm{Ba}_{1} 40^{\mathrm{va}} \mathrm{Be} 83^{\mathrm{r}} \mathrm{Ka} 59^{\mathrm{rb}} \mathrm{Kl} 7_{2^{\mathrm{rb}}} \mathrm{Kr} 86^{\mathrm{ra}} \mathrm{Kr}_{1} 3^{1^{\mathrm{vb}}} \mathrm{Kr}_{2} 291^{\mathrm{va}} \mathrm{Kr}_{3} 239^{\mathrm{v}} L 23^{2^{\mathrm{vb}}} \mathrm{M}$ ${ }_{3} 6^{\mathrm{rb}} \mathrm{Po} 65^{\mathrm{rb}} S g 100^{\mathrm{r}} U 5^{1^{\mathrm{rb}}} \mathrm{Wi} 83^{\mathrm{vb}} W r 94^{\mathrm{r}}$

III.17 Utrum halo fiat per refractionem vel per reflexionem radiorum visualium super vaporem medium inter astrum sub quo halo apparet et visum nostrum $\mathrm{Ba} 57^{\mathrm{ra}} \mathrm{Ba}{ }_{1} 4^{\text {va }} \mathrm{Be} 84^{\mathrm{r}} \mathrm{Ka} 6 \mathrm{o}^{\mathrm{rb}} \mathrm{Kl} 73^{\mathrm{vb}} \mathrm{Kr} 86^{\text {va }} \mathrm{Kr}_{1} 3^{2^{\text {va }}} \mathrm{Kr}_{2} 293^{\text {ra }} \mathrm{Kr}_{3} 241^{\mathrm{r}} L 233^{\text {vb }} M$ $37^{\text {ra }} \mathrm{Po} 66^{\text {rb }} \mathrm{Sg} 102^{\mathrm{r}} U 5^{\text {rb }}$ Wi $84^{\text {va }}$ Wr $96^{\mathrm{r}}$ 
III.18 Utrum halo debeat apparere secundum circuli periferiam vel circumferentiam

$\mathrm{Ba} 5^{8^{\mathrm{va}}} \mathrm{Ba}_{1} 4^{\text {vb }} \mathrm{Be} 85^{\mathrm{r}} \mathrm{Ka} 62^{\text {ra }} \mathrm{Kl} 75^{\text {va }} \mathrm{Kr} 87^{\mathrm{va}} \mathrm{Kr}_{1} 33^{\text {ra }} \mathrm{Kr}_{2} 294^{\text {ra }} \mathrm{Kr}_{3} 267^{\mathrm{r}} L 235^{\text {ra }} \mathrm{M}$ $3^{\text {ra }} \mathrm{Po} 68^{\text {ra }} S g 104^{\mathrm{v}} U 53^{\text {va }} W i 85^{\text {vb }}$ Wr $98^{\mathrm{v}}$

III.19 Utrum radius visualis debeat reflecti ab aere uniformi non condensato nec mixto vaporibus ad oculum videntis existentis in eodem aere sine adiutorio speculorum

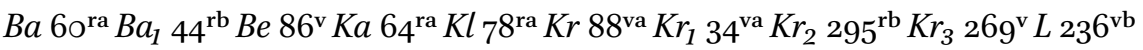
$M 39^{\text {va }} \mathrm{Po} 70^{\text {ra }} S g 108^{\text {r }} U 55^{\text {rb }} W i 87^{\text {ra }} W r 102^{\text {r }}$

III.2O Utrum colores yridis sint colores secundum rei veritatem

$\mathrm{Ba} 61^{\mathrm{vb}} \mathrm{Ba} a_{1} 45^{\mathrm{va}} \mathrm{Be} 88^{\mathrm{r}} \mathrm{Ka} 66^{\mathrm{va}} \mathrm{Kl} 8 \mathrm{o}^{\mathrm{vb}} \mathrm{Kr} 89^{\mathrm{va}} \mathrm{Kr}_{1} 35^{\mathrm{vb}} \mathrm{Kr}_{3} 22^{2} L 239^{\text {ra }} M 4^{\text {ra }} P o$ $7^{\text {va }} S g 112^{\mathrm{r}} U 57^{\text {rb }} W i 88^{\text {va }} W r 105^{\mathrm{v}}$

III.21 Utrum yris sit forma realis nubi impressa vel sit solum forma ymaginaria

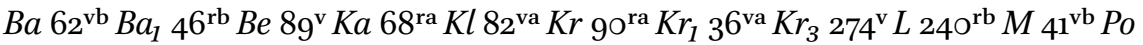
$74^{\text {ra }} S g 114^{\mathrm{v}} U 5^{\text {va }} W i 89^{\text {rb }} W r 107^{\mathrm{v}}$

III.22 Utrum yris sit forma dyaphanalis vel specularis, vel utrum yris fiat per reflexionem vel refractionem

$\mathrm{Ba} 63^{\text {vb }} \mathrm{Ba}_{1} 47^{\mathrm{ra}} \mathrm{Be} 9 \mathrm{9}^{\mathrm{v}} \mathrm{Ka} 69^{\mathrm{rb}} \mathrm{Kl} 84^{\mathrm{ra}} \mathrm{Kr} 9 \mathrm{o}^{\mathrm{vb}} \mathrm{Kr}_{1} 37^{\mathrm{rb}} \mathrm{Kr}_{3} 27^{\mathrm{r}} L 241^{\mathrm{va}} \mathrm{M} 42^{\mathrm{vb}} \mathrm{Po}$ $75^{\text {va }} S g 117^{\text {r }} U 59^{\text {va }} W i 90^{\text {rb }} W r 110^{\mathrm{r}}$

III.23 Utrum, supposito quod yris fiat per reflexionem radiorum, utrum tunc fiat in nube vel super guttulas roridas vel super stillicidia

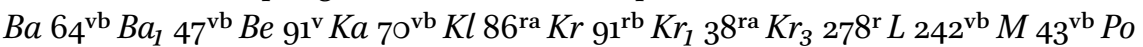
$77^{\mathrm{va}} S g 119^{\mathrm{v}} U 61^{\mathrm{ra}} W i 9^{\mathrm{rb}} W r 112^{\mathrm{v}}$

III.24 Utrum omnis yris debeat esse tricolor

$\mathrm{Ba} 65^{\text {va }} \mathrm{Ba}_{1} 48^{\text {ra }} \mathrm{Be} 92^{\mathrm{r}} \mathrm{Ka} 7^{\text {va }} \mathrm{Kl} 87^{\text {ra }} \mathrm{Kr} 9^{\text {va }} \mathrm{Kr}_{1} 3^{8^{\mathrm{rb}}} \mathrm{Kr}_{3} 27^{\mathrm{v}} L 243^{\text {va }} \mathrm{M} 44^{\text {rb }} \mathrm{Sg}$ $121^{\mathrm{r}} U 61^{\mathrm{vb}} W i 92^{\mathrm{vb}} W r 114^{\mathrm{r}}$

III.25 Utrum yris solum dupliciter et non multipliciter potest apparere $\mathrm{Ba} 66^{\mathrm{rb}} \mathrm{Ba}_{1} 48^{\mathrm{vb}} \mathrm{Be} 93^{\mathrm{r}} \mathrm{Ka} 7^{\text {va }} \mathrm{Kl} 88^{\mathrm{rb}} \mathrm{Kr} 92^{\text {ra }} \mathrm{Kr}_{1} 39^{\text {ra }} \mathrm{Kr}_{3} 280^{\mathrm{r}} \mathrm{L} 244^{\mathrm{va}} \mathrm{M} 45^{\text {ra }} \mathrm{Sg}$ $122^{\mathrm{v}} U 62^{\mathrm{vb}} \mathrm{Wi} 93^{\mathrm{va}} \mathrm{Wr} 115^{\mathrm{v}}$ 
III.26 Utrum semper, apparentibus duabus yridibus, superior yris debeat habere colores conversim positos

$B a 67^{\text {rb }} B a_{1} 49^{\text {va }} B e 93^{\mathrm{v}} K a 74^{\text {rb }} K l 90^{\text {ra }} K r 92^{\text {vb }} K_{1} 39^{\text {va }} K_{3} 281^{\text {v }} L 245^{\text {vb }} M 46^{\text {ra }} S g$ $125^{\mathrm{r}} U 64^{\mathrm{rb}} W i 93^{\mathrm{rb}} \mathrm{Wr} 118^{\mathrm{r}}$

III.27 Utrum yris superior vel secundaria necessarie debeat apparere et esse remissior in coloribus quam principalis yris

$\mathrm{Ba} 68^{\mathrm{rb}} \mathrm{Ba}_{1} 5^{\mathrm{Ob}} \mathrm{Be} 94^{\mathrm{v}} \mathrm{Ka} 75^{\mathrm{va}} \mathrm{Kl} 91^{\mathrm{va}} \mathrm{Kr} 93^{\mathrm{rb}} \mathrm{Kr}_{1} 4^{\mathrm{O}^{\mathrm{rb}}} \mathrm{Kr}_{3} 283^{\mathrm{r}} L 246^{\mathrm{vb}} \mathrm{M} 46^{\mathrm{vb}} S g$ $127^{\mathrm{r}} U 65^{\mathrm{va}} \mathrm{Wi} 94^{\mathrm{ra}} \mathrm{Wr} 120^{\mathrm{r}}$

III.28 Utrum yris debeat apparere secundum circuli periferiam si non sit impedimentum

$\mathrm{Ba} 69^{\mathrm{ra}} \mathrm{Ba} a_{1} 5^{\mathrm{vb}} \mathrm{Be} 95^{\mathrm{r}} \mathrm{Ka} 7^{\mathrm{va}} \mathrm{Kl} 9^{\mathrm{vb}} \mathrm{Kr} 93^{\mathrm{vb}} \mathrm{Kr}_{1} 40^{\mathrm{vb}} \mathrm{Kr}_{3} 284^{\mathrm{v}} L 247^{\mathrm{vb}} M 47^{\mathrm{rb}} \mathrm{Sg}$ $128^{\mathrm{v}} U 66^{\mathrm{va}} \mathrm{Wi} 94^{\mathrm{vb}} \mathrm{Wr} 121^{\mathrm{v}}$

III.29 Utrum semper, tempore apparitionis yridis, necesse sit centrum Solis et centrum horizontis et centrum yridis et polos eorumdem esse in eadem linea recta

$\mathrm{Ba} 7 \mathrm{0}^{\mathrm{va}} \mathrm{Ba} a_{1} 5^{\mathrm{va}} \mathrm{Be} 96^{\mathrm{v}} \mathrm{Ka} 7^{8^{\mathrm{va}}} \mathrm{Kl} 94^{\mathrm{vb}} \mathrm{Kr} 94^{\mathrm{vb}} \mathrm{Kr}_{1} 44^{\text {vb }} \mathrm{Kr}_{3} 287^{\mathrm{r}} L 249^{\mathrm{vb}} M 48^{\mathrm{va}} S g$ $131^{\mathrm{v}} U 68^{\text {va }}$ Wi $96^{\text {ra }}$ Wr $125^{\mathrm{r}}$

III.3o Utrum semper, tempore apparitionis yridis et halonis, dyameter yridis sit precise dupla ad dyametrum halonis

$\mathrm{Ba} 7^{\mathrm{vb}} \mathrm{Ba}{ }_{1} 5^{2^{\mathrm{va}}} \mathrm{Be} 9^{\mathrm{r}} \mathrm{Ka} 8 \mathrm{0}^{\mathrm{vb}} \mathrm{Kl} 97^{\mathrm{rb}} \mathrm{Kr} 95^{\mathrm{vb}} \mathrm{Kr}_{1} 42^{\mathrm{vb}} \mathrm{Kr}_{3} 289^{\mathrm{r}} L 25^{\mathrm{va}} \mathrm{M} 49^{\mathrm{vb}} S g$ $135^{\mathrm{r}} U 7^{\mathrm{va}} \mathrm{Wi} 97^{\mathrm{rb}} \mathrm{Wr} 128^{\mathrm{r}}$

III.31 Utrum, omni hora diei artificialis oculo existente in superficie horizontis, posset aliqua portio yridis apparere ubicumque fuerit homo vel oculus videntis $\mathrm{Ba} 73^{\mathrm{ra}} \mathrm{Ba}{ }_{1} 3^{\mathrm{rb}} \mathrm{Be} 99^{\mathrm{r}} \mathrm{Ka} 82^{\mathrm{vb}} \mathrm{Kl} 99^{\mathrm{rb}} \mathrm{Kr} 96^{\mathrm{vb}} \mathrm{Kr}_{1} 43^{\mathrm{va}} \mathrm{Kr}_{3}{ }_{291^{\mathrm{r}} L} 253^{\mathrm{ra}} \mathrm{M} 5^{0^{\mathrm{vb}}} \mathrm{Sg}$ ${ }_{13} 8^{\mathrm{r}} U 7^{\mathrm{rb}} W i 8^{\mathrm{rb}} W r 13^{\mathrm{r}}$

III.32 Utrum yris Lune potest pluries apparere quam bis in quinquaginta annis in consimilibus coloribus et proprietatibus sicut yris Solis

$\mathrm{Ba} 74^{\mathrm{ra}} \mathrm{Ba}{ }_{1} 54^{\text {ra }} \mathrm{Be} 100^{\mathrm{r}} \mathrm{Ka} 84^{\text {ra }} \mathrm{Kl} 1{ }_{101^{\mathrm{ra}}} \mathrm{Kr} 97^{\mathrm{va}} \mathrm{Kr}_{1} 44^{\text {rb }} \mathrm{Kr}_{3} 293^{\mathrm{r}} L 254^{\text {va }} \mathrm{M} 5^{\text {va }} S g$ $140^{\mathrm{r}} U 73^{\text {va }} W i 99^{\text {ra }} W r 133^{\mathrm{r}}$

III.33 Utrum, visa yride et Sole vel astro elevato notabiliter super horizontem, apparet minor portio maioris circuli quam appareat Sole existente in fine horizontis

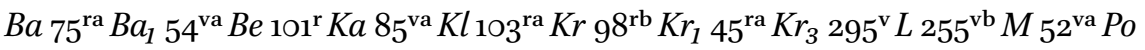
$7^{\mathrm{vb}} S g 142^{\mathrm{v}} U 75^{\mathrm{rb}} W i 99^{\mathrm{vb}} \mathrm{Wr} 135^{\mathrm{v}}$ 
III.34 Utrum virge et parelii fiant ex reflexione vel refractione radiorum sicut yris vel halo

$\mathrm{Ba} 7^{6^{\mathrm{ra}} \mathrm{Ba}} \mathrm{a}_{1} 5^{\mathrm{ra}} \mathrm{Be} 102^{\mathrm{r}} \mathrm{Ka} 87^{\mathrm{rb}} \mathrm{Kl} 1{ }^{\mathrm{O}} 5^{\mathrm{rb}} \mathrm{Kr} 99^{\mathrm{rb}} \mathrm{Kr}_{1} 45^{\mathrm{vb}} K r_{3} 298^{\mathrm{r}} L 257^{\mathrm{rb}} M_{53^{\mathrm{va}}} \mathrm{Po}$ $80^{\text {va }} S g 145^{\mathrm{v}} U 77^{\mathrm{ra}}$ Wi $100^{\mathrm{vb}} \mathrm{Wr} 13^{\mathrm{r}}$

III.35 Utrum per iuvamen artis possunt fieri metalla

$\mathrm{Ba} 7^{\text {vb }} \mathrm{Ba}{ }_{1} 55^{\mathrm{vb}} \mathrm{Be} 103^{\mathrm{r}} \mathrm{Ka} 88^{\mathrm{va}} \mathrm{Kl} 107^{\mathrm{ra}} \mathrm{Kr} 99^{\mathrm{vb}} \mathrm{Kr}_{1} 46^{\mathrm{ra}} K r_{3} 299^{\mathrm{v}} L 25^{8^{\mathrm{va}} M} 54^{\mathrm{rb}}$ Po $82^{\text {ra }} \mathrm{Sg} 147^{\mathrm{v}} U 7^{\mathrm{rb}} \mathrm{Wi} 101^{\mathrm{va}} \mathrm{Wr} 140^{\mathrm{r}}$

IV.1 Utrum tantum quatuor sunt qualitates prime, scilicet caliditas, humiditas, frigiditas, siccitas

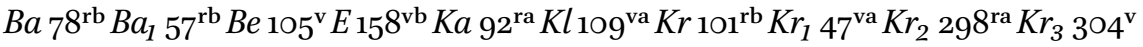
$L 261^{\text {va }} M 5^{6^{\text {rb }}}$ Po $85^{\text {ra }} S g 15^{2} U 81^{\text {vb }} W i 103^{\text {ra } W r} 145^{\text {r }}$

IV.2 Utrum quatuor qualitates, videlicet caliditas, frigiditas, etc., sint principia activa in generatione cuiuslibet mixti, accipiendo tamen 'generationem' pro alteratione precedente introductionem forme substantialis mixti, eo modo quo Aristoteles accipit in secundo capitulo huius quarti

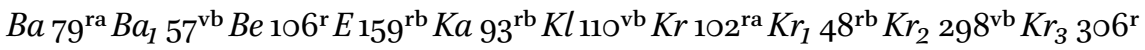
$L 262^{\mathrm{vb}} M 57^{\mathrm{ra}} \mathrm{Po} 86^{\mathrm{rb}} \mathrm{Sg} 155^{\mathrm{r}} U 83^{\mathrm{rb}} W i 103^{\mathrm{vb}} \mathrm{Wr} 146^{\mathrm{v}}$

IV.3 Utrum putrefactio causetur a calido extrinseco fugiente intrinseco

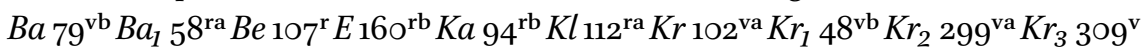
$L 264^{\text {ra }} M 57^{\text {vb }}$ Po $87^{\text {ra }} S g 157^{\text {r }} U 84^{\text {va }} W i 105^{\text {ra }} W r 148^{\text {r }}$

IV.4 Utrum frigus preservat a putrefactione

$\mathrm{Ba} 8 \mathrm{o}^{\mathrm{ra}} \mathrm{Ba} 5_{1} 8^{\mathrm{vb}} \mathrm{Be} 108^{\mathrm{r}} \mathrm{E} 161^{\mathrm{ra}} \mathrm{Ka} 95^{\mathrm{va}} \mathrm{Kl} 113^{\mathrm{rb}} \mathrm{Kr} 103^{\mathrm{ra}} \mathrm{Kr}_{1} 49^{\mathrm{rb}} \mathrm{Kr}_{2} 300^{\mathrm{va}} \mathrm{Kr}_{3} 310^{\mathrm{v}}$ $L 265^{\text {ra }} M 5^{8^{\text {va }}}$ Po $88^{\text {ra }} S g 159^{\mathrm{r}} U 85^{\text {vb } W i ~} 105^{\text {ra }} W r 15^{\circ}$

IV.5 Utrum aliqua animalia possunt generari per putrefactionem

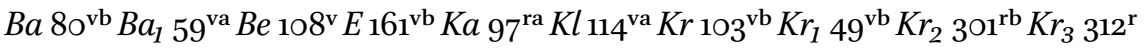
$L 266^{\mathrm{rb}} M 59^{\mathrm{rb}} \mathrm{Po} 89^{\mathrm{rb}} S g{ }_{16} 1^{\mathrm{r}} U 87^{\mathrm{rb}} W i 105^{\mathrm{vb}} W r 15^{\mathrm{v}}$

IV.6 Utrum diffinitio digestionis sit bona in qua dicitur: 'digestio est perfectio a calido naturali et proprio ex oppositis passivis'

$\mathrm{Ba} 81^{\mathrm{rb}} \mathrm{Ba} a_{1} 59^{\mathrm{vb}} \mathrm{Be} 109^{\mathrm{v}} E 162^{\mathrm{va}} K a 9^{\mathrm{ra}} K l 115^{\mathrm{vb}} K r 104^{\mathrm{va}} K_{1} 5^{\mathrm{O}^{\mathrm{rb}}} \mathrm{Kr}_{2} 3{ }^{\mathrm{O}} 2^{\mathrm{ra}} \mathrm{Kr}_{3} 313^{\mathrm{v}}$ $L{ }_{26} 7^{\mathrm{rb}} M 59^{\mathrm{vb}}$ Po $89^{\mathrm{vb}} S g 1_{162^{\mathrm{v}}} U 88^{\mathrm{rb}}$ Wi $106^{\mathrm{rb}} W r 153^{\mathrm{r}}$

IV.7 Utrum balnea conferant ad digestionem

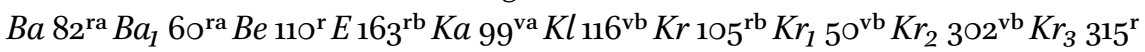
$L 268^{\text {rb } M \text { 6o }}{ }^{\text {va }}$ Po $90^{\text {va }} S g 164^{\text {v }} U 89^{\text {va }} W i 106^{\text {vb }} W r 154^{\text {v }}$ 
IV.8 Utrum sint tantum tres digestiones

$B a 82^{\text {vb }} B a_{1} 61^{\text {ra }} B e 111^{\mathrm{r}} E 164^{\text {ra }} K a 101^{\text {ra }} K l 118^{\text {va }} K r 106^{\text {rb }} K r_{1} 5^{1^{\text {rb }} K r_{2}} 3{ }^{\circ} 3^{\text {vb }} K r_{3} 317^{\mathrm{r}}$ $L 269^{\mathrm{rb}} M 61^{\mathrm{rb}}$ Po $91^{\mathrm{va}} S g{ }_{16} 7^{\mathrm{r}} U 91^{\mathrm{ra}} W i 107^{\mathrm{vb}} W r 15^{6^{\mathrm{v}}}$

IV.9 Utrum frixata debeant magis dici assata quam elixata

$\mathrm{Ba} 83^{\mathrm{vb}} \mathrm{Ba} a_{1} 61^{\mathrm{vb}} \mathrm{Be} 112^{\mathrm{r}} \mathrm{E} 165^{\mathrm{rb}} \mathrm{Ka} 103^{\mathrm{va}} K l_{121^{\mathrm{va}}} K r 107^{\mathrm{va}} K r_{1} 5^{2^{\mathrm{ra}}} \mathrm{Kr}_{2} 3 \mathrm{O} 5^{\mathrm{ra}} K r_{3} 319^{\mathrm{r}}$

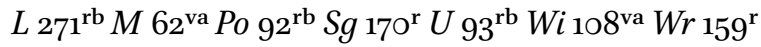

IV.10 Utrum vermes qui generantur in ventribus animalium generentur in stomaco vel in intestinis

$\mathrm{Ba} 84^{\mathrm{va}} \mathrm{Ba} a_{1} 62^{\mathrm{rb}} \mathrm{Be} 113^{\mathrm{r}} E 166^{\mathrm{ra}} K a 105^{\mathrm{ra}} K{ }_{122^{\mathrm{va}}} K r 108^{\mathrm{va}} K r_{1} 5^{2^{\mathrm{va}}} K_{2} 3{ }^{\circ} 5^{\mathrm{vb}} K_{3} 3^{20^{\mathrm{v}}}$ $L 272^{\text {rb }} M 63^{\text {ra }}$ Po $93^{\text {ra }} S g 172^{\text {r }} U 94^{\text {va }} W i 108^{\text {vb }} W r 160^{\text {v }}$

IV.11 Utrum in quolibet mixto dominetur terra vel aqua vel ambo

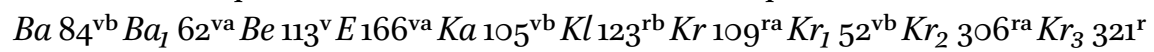

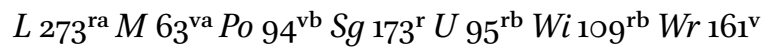

